\title{
Comparative Analysis of the Alien Vascular Flora of Sardinia and Corsica
}

\author{
Selena PUDDU ${ }^{1}$, Lina PODDA ${ }^{1 *}$, Olga MAYORAL ${ }^{2}$, Alain DELAGE ${ }^{3}$, \\ Laetitia HUGOT ${ }^{3}$, Yohan PETIT², Gianluigi BACCHETTA ${ }^{1,4}$ \\ ${ }^{1}$ Università degli Studi di Cagliari, Centro Conservazione Biodiversità (CCB), Dipartimento di Scienze della Vita e dell'Ambiente, v.le S. \\ Ignazio da Laconi 13,09123 Cagliari, Italy; selena.puddu@gmail.com; lina.podda@gmail.com ("corresponding author) \\ ${ }^{2}$ Universitat de València, Dpto. Didáctica de las Ciencias Experimentales y Sociales. Facultat de Magisteri, Avinguda dels Tarongers, 4, 46022; \\ JardíBotànic de la Universitat de València,Valencia,Spain; olga.mayoral@uv.es \\ ${ }^{3}$ Conservatoire Botanique National de Corse, 14 Avenue Jean Nicoli, 20250 Corte, \\ France; Alain.Delage@oec.fr; Laetitia.Hugot@oec.fr; Yohan.Petit@oec.fr \\ ${ }^{4}$ Hortus Botanicus Karalitanus (HBK), Università degli Studi di Cagliari, Viale Sant'Ignazio da Laconi 9-11 09123 Cagliari, \\ Italy; bacchet@unica.it
}

\begin{abstract}
This article provides a comparison of the vascular alien flora of Sardinia (Italy) and that of Corsica (France), both territories belonging to the Western Mediterranean biogeographic subregion. The study has recorded 598 (90 doubtful) alien taxa in Sardinia (18\% of the total flora) while 553 (87 doubtful) in Corsica (17\%); six are new report to Sardinia and 27 to Corsica. A total of 234 taxa are common to both islands. Neophytes are 344 taxa (68\% of the total) in Sardinia and 399 taxa (73\%) in Corsica. The invasive component includes 64 taxa in Sardinia (13\% of the alien flora) and 99 taxa (21\%) in Corsica, 33 of them common to both territories. The total 740 alien taxa of Sardinia and Corsica are included in 93 families; being Fabaceae the richest. The comparison of the biological spectrum reveals that phanerophytes (202 taxa, 40\%) are the most represented in Sardinia and therophytes (149 taxa, 32\%) in Corsica. A study of the geographical origin shows supremacy of the American element in Sardinia (170 taxa, 34\%) and in Corsica (136 taxa, 29\%). The majority of taxa arrived as a result of intentional human introductions, mainly for ornamental use (247 taxa, 49\% in Sardinia; 208 taxa, 45\% in Corsica). Seminatural, agricultural and synanthropic are the most occupied habitats. These data show the need for joint action to stem the increasingly worrying phenomenon of the alien flora in order to reduce the negative effects on natural habitats and native flora.
\end{abstract}

Keywords: alien vascular flora, conservation, invasions, Mediterranean Basin, Tyrrhenian islands

\section{Introduction}

Alien plant species, especially in their invasive and naturalized component, are considered one of the major threats to the conservation of endangered plant species and habitats (Mack et al., 2000; Genovesi and Shine, 2004; Millennium Ecosystem Assessment, 2005; Lambdon et al., 2008). There are many ways alien plants can directly and indirectly menace the preservation of native flora. As regards, among other effects on biodiversity, it is reported that they can change ecosystems through the alteration of soil stability, the promotion of erosion, being vector of parasites and diseases, the colonization of free spaces, the exploitation of natural resources, the accumulation of litter, the promotion or suppression of fire and, together with the more or less massive human intervention, the homogenization of the floras (Vitousek, 1990; Richardson et al., 2000; Winter et al., 2009).

Regarding the severe degree of the impact of alien plants on island ecosystems compared to mainland, different points of view have been developed so far. In fact, if on the one hand there is who sustains that island ecosystems, and especially those of the Mediterranean Basin, are more susceptible to alien plant invasions (Sala et al., 2000; Sax and Gaines, 2008), on the other hand more recent doubts have been expressed concerning the different impact that plant invasions could actually have on the native floras of mainland respect to islands (Vilà et al., 2011). 
338

Notwithstanding, islands usually harbour very particular floras, due to their geographical isolation, by the presence of a high number of endemics that deserve absolute protection from the various menaces that threaten the integrity of their populations up to the survival of the species (Fenu et al., 2014; Thompson, 2005).

Sardinia (Italy) and Corsica (France) are two important centres of plant biodiversity belonging to the Tyrrhenian Islands hotspot (Cañadas et al., 2014; Médail and Quézel, 1997, 1999; Médail and Diadema, 2009; Zachos and Habel, 2011).

With regard to the latest checklist updates, the Sardinian flora included 2494 taxa (Conti et al., 2005, 2007) of which 347 are endemics (Bacchetta et al., 2005), while Corsica, though being pretty smaller, harbours a flora of 2680 taxa, with an endemic component of 284 taxa (Jeanmonod et al., 2015). The high percentages of endemics, many of them being strictly exclusive to Sardinia and/or Corsica, meet the also relatively high amount of alien plant species of the floras of the two islands: according to the last report made by Podda et al. (2012), the alien component for Sardinia reached the amount of 541, of which 58 are invasive, while in the latest study of the Corsican alien flora carried out by Jeanmonod et al. (2011, 2015) non-native component accounted 443 taxa, of which 31 are invasive or potentially invasive.

Unfortunately, it cannot be omitted that both in Sardinia and Corsica many fragile habitats and some endangered and endemic taxa are at risk of disappearance (Bacchetta et al., 2012; Cañadas et al., 2014). It is also noteworthy that the two islands are major touristic destinations in the Mediterranean, especially concerning beach tourism thus entailing an exceptional land use in coastal areas that, together with other natural and seminatural habitats, are also constantly threatened by other menaces such as recurring fires, exaggerated herbivorism, overexploitation of natural resources, increasing urbanization and the subsequent land degradation (Vacca et al., 2002; Delbosc, 2015).

In a context of an increasing menace by the continuous rising percentages of alien plant taxa, an update of the checklist of the alien vascular flora and the analysis of its components is useful to get a snapshot of the current composition of the non-native components. Moreover, the comparison of the invasive alien floras of two biogeographically related areas such as the islands of Sardinia and Corsica - especially in the framework of a broad survey on the alien plants distribution in islands of the Mediterranean Basin - can provide an insight of which are the processes that act as primary drivers of the introduction and the subsequent invasion of alien plants in Mediterranean insular habitats.

In this paper, the results of the comparison between the alien floras of Sardinia and Corsica are reported, as inferred from field investigations and from the latest literature. Special care has been put into the analysis of the chorology, the life form, the type (if neophyte or archaeophyte), the diffusion (if invasive, naturalized or casual), the pathway of introduction and the most affected habitats in relation to the two alien floras.

\section{Materials and Methods}

The basis of the current comparative analysis is the latest update of the Sardinian alien flora checklist (Podda et al., 2012) and the recent revisions of the "Catalogue des Tracheophytes de Corse" (CBNC, 2014). The two checklists have been subjected to revision and updated based on field investigations, literature and herbarium data. Those taxa that had been recorded in the past and for which there is no certainty concerning their actual presence in the studied areas, were considered of doubtful presence and marked by the letter $\mathrm{D}$.

Plant taxa have been classified as archaeophytes or neophytes on the basis of their introduction before or after 1492/1500 A.D., respectively. Concerning the taxa for which doubts still persist, regarding their status (alien or native), we have preferred the attribution of doubtful alien $(\mathrm{Da})$.

The status of invasiveness has followed that proposed by Richardson et al. (2000) and subsequently elaborated and reviewed by Pyšek et al. (2004) and Richardson et al. (2011).

In particular, Sardinian taxa have been attributed to the classes of invasive, naturalized and casual plants on the basis of the current literature as well as on field observations, while for Corsican taxa we mainly followed what was reported by the Conservatoire Botanique National de Corse (2014) with minor modifications together with what was observed during field investigations.

From a nomenclatural point of view and for the attribution of the taxa to the plant families we have followed the on-line databases of The Plant List website (2016) and that of the Med-Checklist website (Euro+Med, 2006-onwards).

Plant families have been validated according to what is reported in the Angiosperm Phylogeny Group III (Chase and Reveal, 2009; Stevens, 2001-onwards) and in the works of Christenhusz et al. (2011a, 2011b). Moreover, when available, dedicated taxonomic revisions have been taken into account.

Regarding biological forms, Raunkiaer life form classification (Raunkiaer, 1934) was followed, with the variations and abbreviations used by Pignatti (1982), while geographic origin was based on what was basically reported by Podda et al. (2012) and by Jeanmonod and Gamisans (2013).

The way of introduction of the alien taxa, when known, was first defined as intentional or unintentional, according to the definitions proposed by the Convention on Biological Diversity (CBD) (Miller et al., 2006). Regarding introduction pathways, the categories proposed by Sanz-Elorza et al. (2004) and Hulme et al. (2008), already adopted by Podda et al., (2012), have been followed: (1) ornamental; (2) agriculture; (3) forestry; (4) seed contaminants; (5) hitchhikers.

Each taxon has been linked to the habitat where it mostly shows its invasiveness and then ordered in the following seven categories as already proposed by Podda et al., (2012): (1) agricultural; (2) synanthropic; (3) coastal; (4) matorral; (5) woodland; (6) riparian; (7) wetland.

The taxa that are known to be cultivated for ornamental or forestry purposes and that do not show any degree of spontaneization have not been taken into account in the present work.

Calculations have been made excluding those taxa from the category of doubtful species in relation to their actual presence in the studied area $(D)$ or to their alien or native status $(\mathrm{Da})$. 
In order to study differences among the alien floras of Sardinia and Corsica the non-parametric U test MannWhitney was applied using version 16 (Minitab Inc.) of MINITAB@.

\section{Results}

The total alien flora of the two territories includes 740 taxa. Sardinian alien flora in total is composed of 598 taxa, representing the $18 \%$ of the whole Sardinian vascular flora. An increase of 61 taxa has been registered in comparison to the last update (Podda et al., 2012). Corsican alien flora is composed of 553 taxa, representing the $17 \%$ of the whole Corsican flora. An increase of 40 taxa has been registered in comparison to the last update (Jeanmonod and Gamisans, 2013) (Annex 1).

Considering the previous known data, six new alien taxa have been found in the island of Sardinia (Table 1).

Regarding the island of Corsica, 27 new alien taxa are reported (Table 2).

The proportion of doubtful entities in Sardinia in relation to the total alien $\operatorname{taxa}(598)$ is of around a 15\%, from which 23

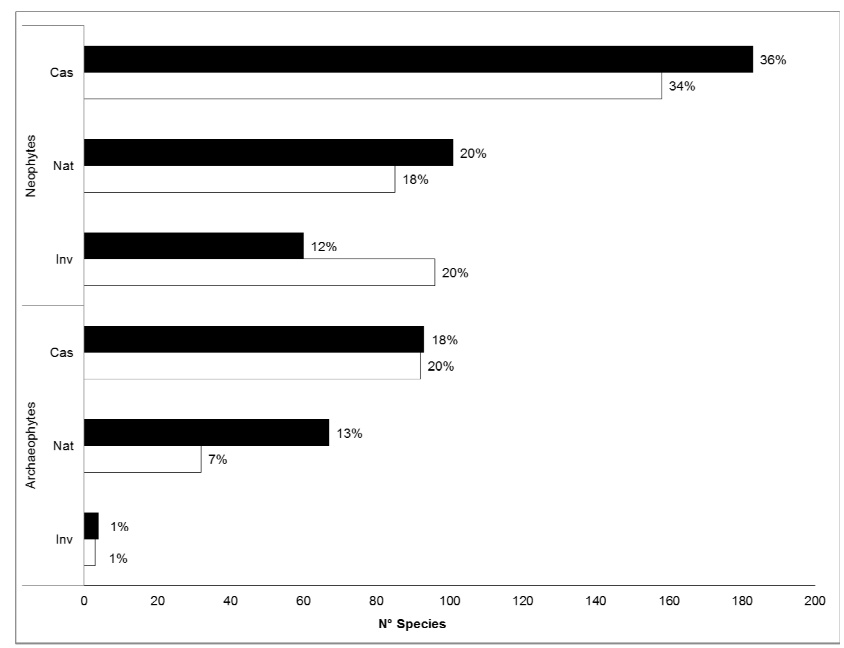

Fig. 1. Numerical and percentage comparison of invasive (Inv), naturalized (Nat) and casual species (Cas), distinguishing archaeophytes and neophytes from the total alien flora in Sardinia (black) and the Corsica (white) taxa are considered of doubtful presence (" $\mathrm{D}$ "), 62 are in doubt in relation to their alien or native status ("Da") and five are both "D" and "Da".

Regarding Corsica, from the 553 alien taxa, 31 are considered of doubtful presence ("D"), 47 of doubtful alien origin ("Da") and nine both "D" and "Da".

Of the 508 remaining alien taxa (without considering "D" and "Da" entities) in Sardinia, 164 are archaeophytes (32\%) and 344 neophytes (68\%) while Corsican alien flora includes 466 taxa, of which 127 are archaeophytes (27\%) and 339 neophytes (73\%) (Fig. 1).

The number of invasive neophytes is 60 (12\%) and 96 (20\%) for Sardinia and Corsica respectively. The amount of other neophytes (naturalized and casual) is of 101 and 183 respectively (20\% and 36\%) for Sardinia and 85 and 158 respectively (18\% and 34\%) for Corsica. Regarding archaeophytes, only a small percentage is invasive (1\%), both for Sardinia and Corsica, while for those naturalized and casual it is higher (13\% and 18\% Sardinia; $7 \%$ and 20\% Corsica) (Fig. 1). The Mann-Whitney test confirmed no significant differences between the medians of the samples considered $(\mathrm{U}$ $=4, \mathrm{p}=0.8852$ ).

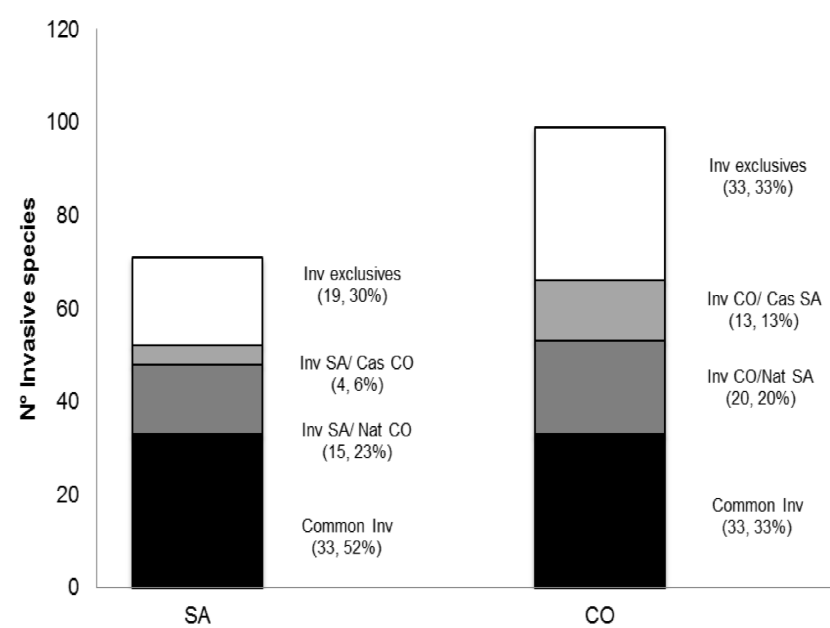

Fig. 2. Comparison of each type of alien plants in Sardinia and Corsica (Inv= invasive; Nat $=$ naturalized; Cas= casual). Percentages consider the total alien flora

Table 1. New taxa for the Sardinian alien flora

\begin{tabular}{|c|c|c|c|c|c|c|}
\hline No & Taxa & $\begin{array}{l}\text { Site/Location } \\
\text { (place name, } \\
\text { municipality, } \\
\text { province) }\end{array}$ & $\begin{array}{l}\text { Coord. Geogr. } \\
\text { (datum WGS 84) }\end{array}$ & $\begin{array}{l}\text { Elevation } \\
\quad(\mathrm{m})\end{array}$ & Habitat & $\begin{array}{l}\text { Thermotype and } \\
\text { ombrotype }\end{array}$ \\
\hline 1 & Aucuba japonica Thunb. & Cagliari (CA) & $\begin{array}{l}39^{\circ} 12^{\prime} 46.59^{\prime \prime} \mathrm{N} \\
9^{\circ} 6 ' 53.73^{\prime \prime} \mathrm{E}\end{array}$ & 6 & Synanthropic & $\begin{array}{l}\text { Thermomedit. sup. } \\
\text { Dry inf. }\end{array}$ \\
\hline 2 & Cedrus deodara (Roxb. ex Lamb.) G. Don. & $\begin{array}{l}\text { Sos Nibberos, } \\
\text { Bono (SS) }\end{array}$ & $\begin{array}{l}40^{\circ} 25^{\prime} 21.82^{\prime \prime} \mathrm{N} \\
8^{\circ} 59^{\prime} 28.48^{\prime \prime} \mathrm{E}\end{array}$ & 1004 & Woodland & $\begin{array}{l}\text { Supratemp. Inf. } \\
\text { Humid sup. }\end{array}$ \\
\hline 3 & $\begin{array}{l}\text { Opuntia microdasys (Lehm.) Pfeiff. subsp. } \\
\text { microdasys }\end{array}$ & Elmas (CA) & $\begin{array}{l}39^{\circ} 14^{\prime} 33.81 " \mathrm{~N} \\
9^{\circ} 5^{\prime} 7.83^{\prime \prime} \mathrm{E}\end{array}$ & 8 & Synanthropic & $\begin{array}{l}\text { Thermomedit. sup. } \\
\text { Dry inf. }\end{array}$ \\
\hline 4 & Proboscidea louisianica (Mill.) Thell. & Assemini (CA) & $\begin{array}{l}39^{\circ} 17^{\prime} 54.80^{\prime \prime} \mathrm{N} \\
9^{\circ} 0^{\prime} 4.34 " \mathrm{E}\end{array}$ & 11 & Synanthropic & $\begin{array}{l}\text { Thermomedit. sup. } \\
\text { Dry inf. }\end{array}$ \\
\hline 5 & Prunus mahaleb L. & $\begin{array}{l}\text { Vivaio forestale, } \\
\text { Talana (OG) }\end{array}$ & $\begin{array}{l}40^{\circ} 33^{\prime} 43.99^{\prime \prime} \mathrm{N} \\
9^{\circ} 27^{\prime} 32.19^{\prime \prime} \mathrm{E}\end{array}$ & 1094 & Woodland & $\begin{array}{l}\text { Supramedit. Inf. } \\
\text { Humid inf. }\end{array}$ \\
\hline 6 & Sedum palmeri S. Watson. & Cagliari (CA) & $\begin{array}{l}39^{\circ} 13^{\prime} 9.89^{\prime \prime} \mathrm{N} \\
9^{\circ} 66^{\prime} 59.39^{\prime \prime} \mathrm{E}\end{array}$ & 95 & Synanthropic & $\begin{array}{l}\text { Thermomedit. sup. } \\
\text { Dry inf. }\end{array}$ \\
\hline
\end{tabular}


Table 2. New taxa for the Corsican alien flora

\begin{tabular}{|c|c|c|c|c|c|c|}
\hline No & Taxa & $\begin{array}{l}\text { Site/Location } \\
\text { (place name, } \\
\text { municipality, } \\
\text { province) }\end{array}$ & $\begin{array}{l}\text { Coord. Geogr. } \\
\text { (datum WGS 84) }\end{array}$ & $\begin{array}{l}\text { Elevation } \\
\quad(\mathrm{m})\end{array}$ & Habitat & $\begin{array}{l}\text { Thermotype and } \\
\text { ombrotype }\end{array}$ \\
\hline 1 & Acacia longifolia (Andrews) Willd. & San-Giuliano & $\begin{array}{c}42^{\circ} 17^{\prime} 22.632^{\prime \prime} \mathrm{N} \\
9^{\circ} 33^{\prime} 22.5^{\prime \prime} \mathrm{E}\end{array}$ & 7 & Coastal & $\begin{array}{l}\text { Mésomedit. Inf. Dry } \\
\text { sup. }\end{array}$ \\
\hline 2 & Acacia retinoides Schlcht. & Bonifacio & $\begin{array}{l}41^{\circ} 25^{\prime} 22.404^{\prime \prime} \mathrm{N} \\
9^{\circ} 13^{\prime} 31.584^{\prime \prime} \mathrm{E}\end{array}$ & 2 & Coastal & $\begin{array}{l}\text { Thermomedit. Dry } \\
\text { sup. }\end{array}$ \\
\hline 3 & $\begin{array}{l}\text { Actinidia deliciosa (A. Chev.) C.F. Liang } \\
\text { \& A.R. Ferguson }\end{array}$ & Poggio-Mezzana & $\begin{array}{l}42^{\circ} 23^{\prime} 51.72^{\prime \prime} \mathrm{N} \\
9^{\circ} 29^{\prime} 40.307^{\prime \prime} \mathrm{E}\end{array}$ & 55 & Agricultural & $\begin{array}{l}\text { Mésomedit. Inf. Dry } \\
\text { sup. }\end{array}$ \\
\hline 4 & Albizia julibrissin Durazz. & Conca & $\begin{array}{l}41^{\circ} 44^{\prime} 42.792^{\prime \prime} \mathrm{N} \\
9^{\circ} 24^{\prime} 22.680^{\prime \prime} \mathrm{E}\end{array}$ & 25 & Synanthropic & $\begin{array}{l}\text { Thermomedit.Dry } \\
\text { sup. }\end{array}$ \\
\hline 5 & $\begin{array}{l}\text { Adonis annua L. subsp. cupaniana } \\
\text { (Guss.) C. Steinb. }\end{array}$ & Bonifacio & $\begin{array}{l}41^{\circ} 24^{\prime} 2.124^{\prime \prime} \mathrm{N} \\
9^{\circ} 12^{\prime} 7.344^{\prime \prime} \mathrm{E}\end{array}$ & 55 & Agricultural & $\begin{array}{l}\text { Mésomedit. Inf. Dry } \\
\text { sup. }\end{array}$ \\
\hline 6 & Agrostemma githago L. & Bonifacio & $\begin{array}{c}41^{\circ} 23^{\prime} 58.236^{\prime \prime} \mathrm{N} \\
9^{\circ} 12^{\prime} 48.852^{\prime \prime} \mathrm{E}\end{array}$ & 30 & Agricultural & $\begin{array}{l}\text { Mésomedit. Inf. Dry } \\
\text { sup. }\end{array}$ \\
\hline 7 & Amaranthus blitum L. subsp. blitum & Figari & $\begin{array}{l}41^{\circ} 29^{\prime} 35.59^{\prime \prime} \mathrm{N} \\
9^{\circ} 5^{\prime} 22.344^{\prime \prime} \mathrm{E}\end{array}$ & 5 & Agricultural & $\begin{array}{l}\text { Mésomedit. Inf. Dry } \\
\text { sup. }\end{array}$ \\
\hline 8 & Anthemis cretica $\mathrm{L}$. & Giuncaggio & $\begin{array}{l}42^{\circ} 11^{\prime} 5.964^{\prime \prime} \mathrm{N} \\
9^{\circ} 22^{\prime} 8.472^{\prime \prime} \mathrm{E}\end{array}$ & 120 & Synanthropic & $\begin{array}{l}\text { Mésomedit. Inf. Dry } \\
\text { sup. }\end{array}$ \\
\hline 9 & Antirrbinum latifolium $\mathrm{L}$. & Grosseto-Prugna & $\begin{array}{l}41^{\circ} 54^{\prime} 16.20^{\prime \prime} \mathrm{N} \\
8^{\circ} 48^{\prime} 8.28^{\prime \prime} \mathrm{E}\end{array}$ & 10 & Synanthropic & $\begin{array}{l}\text { Mésomedit. Inf. Dry } \\
\text { sup. }\end{array}$ \\
\hline 10 & Brassica rapa L. s.l. & Biguglia & $\begin{array}{l}42^{\circ} 37^{\prime} 37.92^{\prime \prime} \mathrm{N} \\
9^{\circ} 25^{\prime} 14.628^{\prime \prime} \mathrm{E}\end{array}$ & 15 & Agricultural & $\begin{array}{l}\text { Mésomedit. Inf. Dry } \\
\text { sup. }\end{array}$ \\
\hline 11 & Cota tinctoria (L.) J. Gay & Tralonca & $\begin{array}{l}42^{\circ} 20^{\prime} 37.32^{\prime \prime} \mathrm{N} \\
9^{\circ} 12^{\prime} 36.467^{\prime \prime} \mathrm{E}\end{array}$ & 810 & Synanthropic & $\begin{array}{l}\text { Mésomedit. Sup. } \\
\text { Dry sup. }\end{array}$ \\
\hline 12 & $\begin{array}{l}\text { Cynosurus echinatus L. var. giganteus } \\
\text { Salis }\end{array}$ & Borgo & $\begin{array}{l}42^{\circ} 35^{\prime} 56.11^{\prime \prime} \mathrm{N} \\
9^{\circ} 28^{\prime} 48.396^{\prime \prime} \mathrm{E}\end{array}$ & 4 & Agricultural & $\begin{array}{l}\text { Mésomedit. Inf. Dry } \\
\text { sup. }\end{array}$ \\
\hline 13 & Ligustrum lucidum W.T. Aiton & Peri & $\begin{array}{l}42^{\circ} 0^{\prime} 10.33^{\prime \prime} \mathrm{N} \\
8^{\circ} 53^{\prime} 22.52^{\prime \prime} \mathrm{E}\end{array}$ & 160 & Synanthropic & $\begin{array}{l}\text { Mésomedit. Inf. Dry } \\
\text { inf. }\end{array}$ \\
\hline 14 & Lycium barbarum $\mathrm{L}$. & Cargèse & $\begin{array}{l}42^{\circ} 10^{\prime} 15.56^{\prime \prime} \mathrm{N} \\
8^{\circ} 35^{\prime} 31.81^{\prime \prime} \mathrm{E}\end{array}$ & 3 & Synanthropic & $\begin{array}{l}\text { Thermomedit. Dry } \\
\text { sup. }\end{array}$ \\
\hline 15 & $\begin{array}{l}\text { Malephora crocea Schwantes var. } \\
\text { purpureo-crocea (Haw.) H. Jacobsen \& } \\
\text { Schwantes }\end{array}$ & Calvi & $\begin{array}{c}42^{\circ} 34^{\prime} 56.64^{\prime \prime} \mathrm{N} \\
8^{\circ} 43^{\prime} 31.54^{\prime \prime} \mathrm{E}\end{array}$ & 40 & Coastal & $\begin{array}{l}\text { Mésomedit. Inf. Dry } \\
\text { sup. }\end{array}$ \\
\hline 16 & Picris hieracioides L. subsp. hieracioides & Valle-di-Rostino & $\begin{array}{l}42^{\circ} 28^{\prime} 11.68^{\prime \prime} \mathrm{N} \\
9^{\circ} 15^{\prime} 1.367^{\prime \prime} \mathrm{E}\end{array}$ & 175 & Synanthropic & $\begin{array}{l}\text { Mésomedit. Inf. Dry } \\
\text { sup. }\end{array}$ \\
\hline 17 & Pistia stratiotes $\mathrm{L}$. & Ajaccio & $\begin{array}{l}41^{\circ} 54^{\prime} 29.9^{\prime \prime} \mathrm{N} \\
8^{\circ} 47^{\prime} 52.29^{\prime \prime} \mathrm{E}\end{array}$ & 2 & Wetland & $\begin{array}{l}\text { Mésomedit. Inf. Dry } \\
\text { sup. }\end{array}$ \\
\hline 18 & $\begin{array}{l}\text { Reynoutria } \times \text { bohemica Chrtek \& } \\
\text { Chrtkova }\end{array}$ & Cargèse & $\begin{array}{l}42^{\circ} 8^{\prime} 2.004^{\prime \prime} \mathrm{N} \\
8^{\circ} 35^{\prime} 46.14^{\prime \prime} \mathrm{E}\end{array}$ & 60 & Synanthropic & $\begin{array}{l}\text { Thermomedit. Dry } \\
\text { sup. }\end{array}$ \\
\hline 19 & Setaria verticillata (L.) P. Beauv. & $\begin{array}{l}\text { Penta-di- } \\
\text { Casinca }\end{array}$ & $\begin{array}{l}42^{\circ} 26^{\prime} 32.17^{\prime \prime} \mathrm{N} \\
9^{\circ} 31^{\prime} 19.67^{\prime \prime} \mathrm{E}\end{array}$ & 5 & Synanthropic & $\begin{array}{l}\text { Mésomedit. Inf. Dry } \\
\text { sup. }\end{array}$ \\
\hline 20 & $\begin{array}{l}\text { Setaria verticillata var. ambigua (Guss.) } \\
\text { Parl. }\end{array}$ & Calvi & $\begin{array}{l}42^{\circ} 33^{\prime} 19.33^{\prime \prime} \mathrm{N} \\
8^{\circ} 47^{\prime} 20.47^{\prime \prime} \mathrm{E}\end{array}$ & 8 & Synanthropic & $\begin{array}{l}\text { Mésomedit. Inf. Dry } \\
\text { sup. }\end{array}$ \\
\hline 21 & $\begin{array}{l}\text { Tragopogon porrifolius subsp. eriospermus } \\
\text { (Ten.) Greuter }\end{array}$ & Porto-Vecchio & $\begin{array}{l}41^{\circ} 35^{\prime} 28.68^{\prime \prime} \mathrm{N} \\
9^{\circ} 16^{\prime} 49.19^{\prime \prime} \mathrm{E}\end{array}$ & 60 & Synanthropic & $\begin{array}{l}\text { Mésomedit. Inf. } \\
\text { Dry sup. }\end{array}$ \\
\hline 22 & Ulex europaeus $\mathrm{L}$. & Corbara & $\begin{array}{l}42^{\circ} 36^{\prime} 55.80^{\prime \prime} \mathrm{N} \\
8^{\circ} 54^{\prime} 27.83^{\prime \prime} \mathrm{E}\end{array}$ & 290 & Matorrals & $\begin{array}{l}\text { Mésomedit. Inf. } \\
\text { Dry sup. }\end{array}$ \\
\hline 23 & Vachellia farnesiana (L.) Wight \& Arn. & Ajaccio & $\begin{array}{l}41^{\circ} 54^{\prime} 29.10^{\prime \prime} \mathrm{N} \\
8^{\circ} 41^{\prime} 1.10^{\prime \prime} \mathrm{E}\end{array}$ & 5 & Synanthropic & $\begin{array}{l}\text { Thermomedit. Dry } \\
\text { sup. }\end{array}$ \\
\hline 24 & Washingtonia robusta $\mathrm{H}$. Wendl. & Ajaccio & $\begin{array}{l}41^{\circ} 55^{\prime} 1.56^{\prime \prime} \mathrm{N} \\
8^{\circ} 44^{\prime} 2.51^{\prime \prime} \mathrm{E}\end{array}$ & 40 & Synanthropic & $\begin{array}{l}\text { Thermomedit. Dry } \\
\text { sup. }\end{array}$ \\
\hline 25 & Wisteria sinensis (Sims) Sweet & Calvi & $\begin{array}{l}42^{\circ} 34^{\prime} 7.32^{\prime \prime} \mathrm{N} \\
8^{\circ} 45^{\prime} 39.71^{\prime \prime} \mathrm{E}\end{array}$ & 15 & Synanthropic & $\begin{array}{l}\text { Mésomedit. Inf. Dry } \\
\text { sup. }\end{array}$ \\
\hline 26 & Yucca filamentosa $\mathrm{L}$. & $\begin{array}{l}\text { Penta-di- } \\
\text { Casinca }\end{array}$ & $\begin{array}{l}42^{\circ} 26^{\prime} 59.57^{\prime \prime} \mathrm{N} \\
9^{\circ} 32^{\prime} 30.08^{\prime \prime} \mathrm{E}\end{array}$ & 3 & Coastal & $\begin{array}{l}\text { Mésomedit. Inf. Dry } \\
\text { sup. }\end{array}$ \\
\hline 27 & Yucca gloriosa $\mathrm{L}$. & Monticello & $\begin{array}{l}42^{\circ} 38^{\prime} 8.34^{\prime \prime} \mathrm{N} \\
8^{\circ} 57^{\prime} 59.65^{\prime \prime} \mathrm{E}\end{array}$ & 10 & Coastal & $\begin{array}{l}\text { Mésomedit. Inf. Dry } \\
\text { sup. }\end{array}$ \\
\hline
\end{tabular}

A total of 234 taxa are common to Sardinia and Corsica, from which the $33 \%$ are naturalized, the $45 \%$ casual and the $22 \%$ invasive in Sardinia, while in Corsica the $24 \%$ are naturalized, the $48 \%$ casual and the $28 \%$ invasive (Table 3). The Mann-Whitney test confirmed no significant differences between the medians of the samples considered $(\mathrm{U}=3, \mathrm{p}=$
$1,0000)$ for section "Total" and for the section "In common".

Invasive taxa common to both territories are 33. Regarding the other invasive taxa, 19 are exclusive to Sardinia and 33 to Corsica. The number of taxa behaving as invasive in Sardinia and naturalized in Corsica is 15 , while 20 are invasive in Corsica and naturalized in Sardinia (Fig. 2). Regarding the 
Table 3. Comparison of the number of common alien taxa of Sardinia and Corsica

\begin{tabular}{ccccc}
\hline \multirow{2}{*}{ Status of invasivity } & & Total & & In common \\
\cline { 2 - 5 } & Sardinia & Corsica & Sardinia & Corsica \\
\hline Naturalized & 168 & 117 & 77 & 55 \\
Casual & 276 & 250 & 105 & 113 \\
Invasive & 64 & 99 & 52 & 66 \\
Total & 508 & 466 & 234 & 234 \\
\hline
\end{tabular}

60

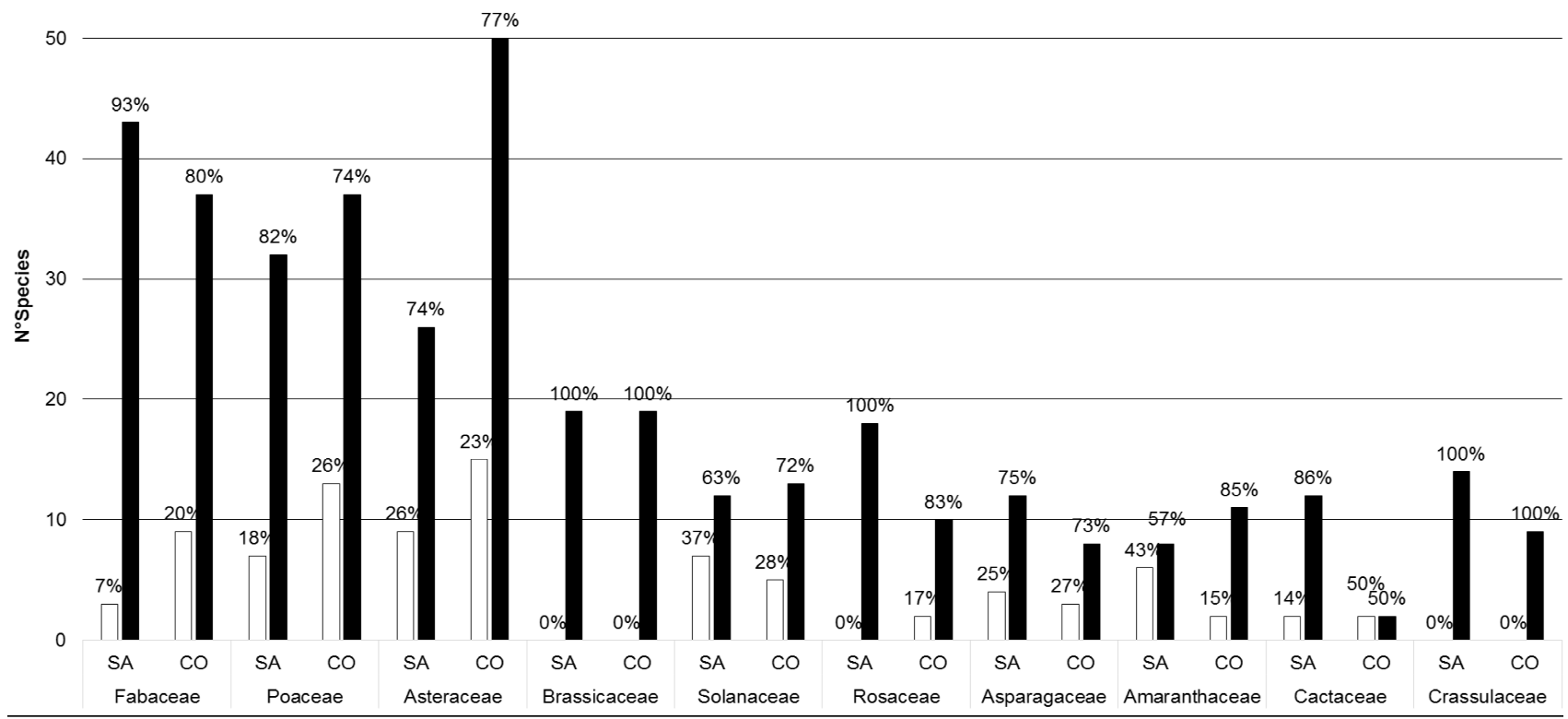

Fig. 3. Comparison of the number of invasive species (white) and naturalized plus casual (black) for each family in Sardinia and in Corsica

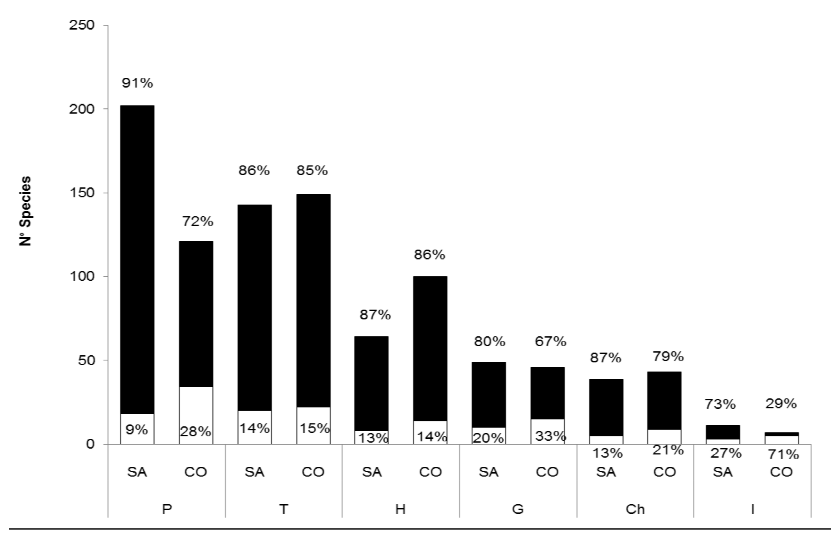

Fig. 4. Comparison of the life forms of invasive (white) alien flora and other (black) alien species (naturalized and casual) in Sardinia and Corsica. Note: T: therophytes, P: phanerophytes, $\mathrm{H}$ : hemicryptophytes, Ch: chamaephytes, G: geophytes, I: hydrophytes

status, the Mann-Whitney test showed no significant differences between the medians of the samples considered ( $U$ $=4, \mathrm{p}=1,0000)$.

The alien flora of Sardinia includes 93 families; Fabaceae is the richest one (46 taxa), followed by Poaceae (39), Asteraceae (35), Brassicaceae and Solanaceae (both 19). Corsican alien flora

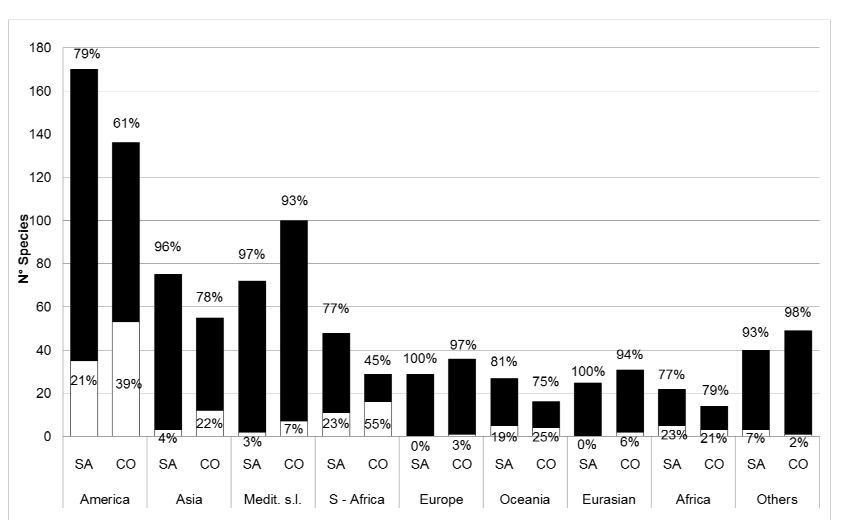

Fig. 5. Comparison of the geographical origin of invasive (white) alien flora and other (black) alien taxa (naturalized and casual) in Sardinia and Corsica

also includes 93 families, among which the most represented are Asteraceae (65), Poaceae (50), Fabaceae (46), Brassicaceae (19) and Solanaceae (18) (Fig. 3). The Mann-Whitney test showed no significant differences between the medians of the different families of the samples considered $(U=14, p=$ 0,6959). 
342

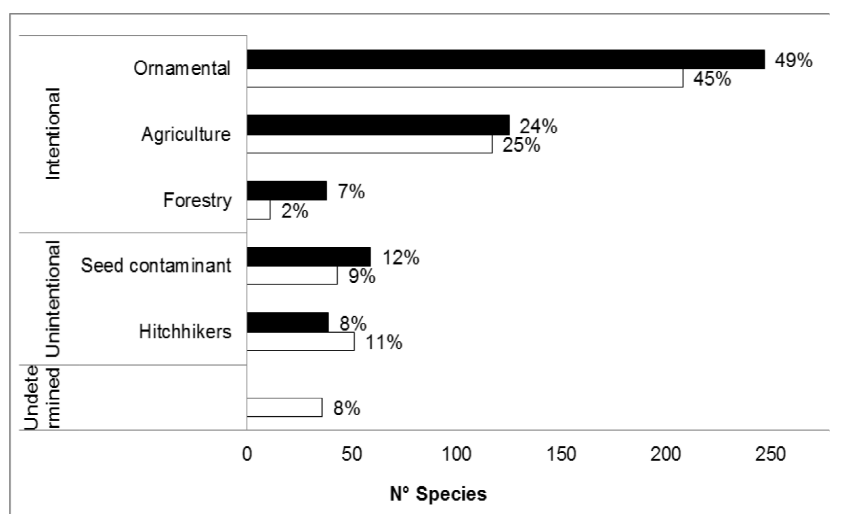

Fig. 6. Comparison of different introduction pathways of alien flora in Sardinia (black) and Corsica (white)

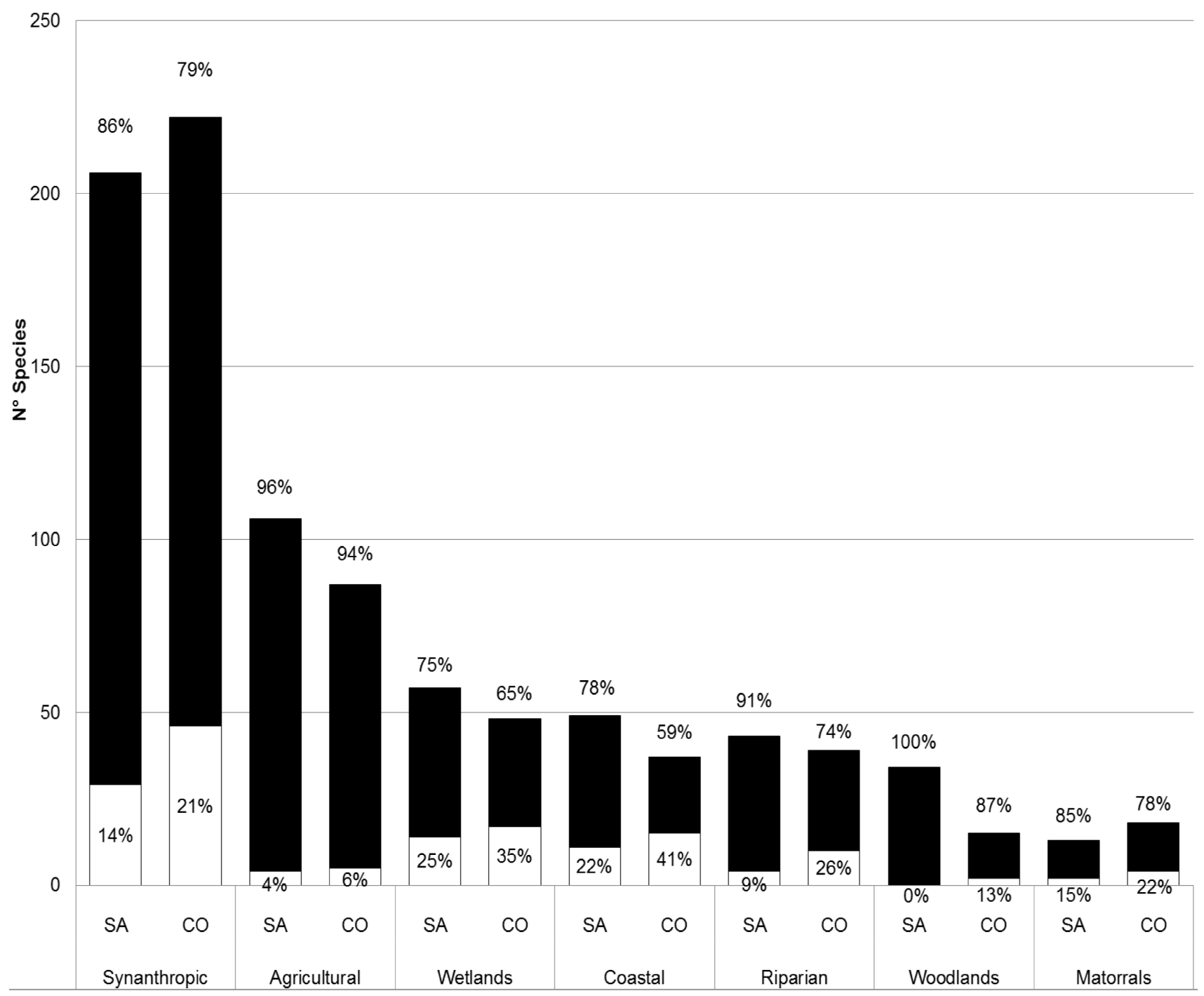

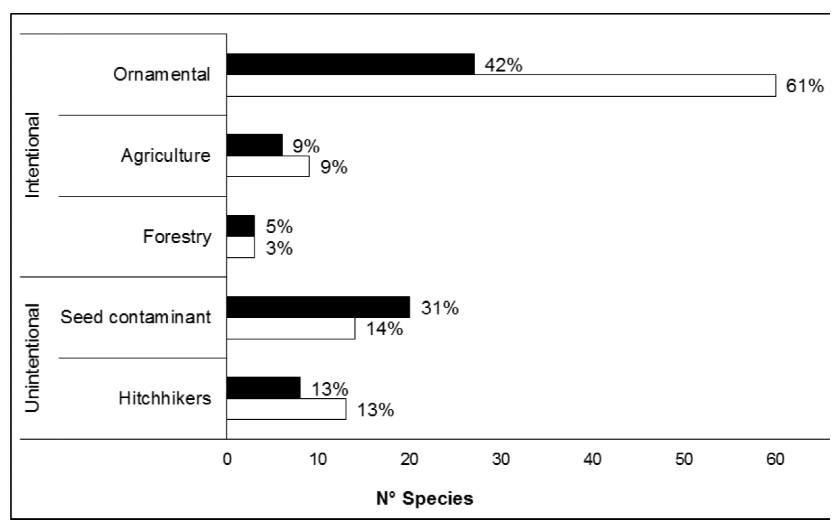

Fig. 7. Comparison of different introduction pathways of invasive species in Sardinia (black) and Corsica (white)

Fig. 8. Comparison of habitats affected by invasive (white) alien taxa and other (black) alien plants (naturalized and casual) in Sardinia and Corsica

Concerning invasive taxa, the most represented families in Sardinia and Corsica are Asteraceae ( 9 and 15 taxa respectively), Poaceae (7 and 13 taxa), Solanaceae ( 7 and 5 taxa) and Fabaceae (3 and 9 taxa) (Fig. 3). In this case the MannWhitney test also showed no significant differences between the medians of the different families of the samples considered 
hemicryptophytes compose the major group being represented by 149 (32\%), $121(26 \%)$ and 100 (21\%) taxa respectively, followed by geophytes and chamaephytes. The MannWhitney test showed no significant differences between the medians of the samples considered $(\mathrm{U}=6, \mathrm{p}=1,0000)$.

The analysis of the invasive component of Sardinia shows that therophytes and phanerophytes are again the most abundant life forms with 20 (31\%) and 18 taxa (28\%) respectively followed by a substantial contribution of geophytes. Among the invasive alien plants of Corsica phanerophytes constitute the relative majority with 34 taxa (35\%) against therophytes (22 taxa, 22\%), while the other life forms provide minor contributions. Both in Sardinia and Corsica hydrophytes are poorly represented (Fig. 4). The Mann-Whitney test showed no significant differences between the medians of the samples considered $(U=6, p=0,9362)$.

Regarding the geographical origin, the major source of alien taxa for Sardinia is represented by the American component (170 taxa, 34\%), followed by the Asian (75 taxa, 15\%) and the Mediterranean sensu lato (72 taxa, 14\%). For Corsica, the American origin also makes far the largest group with 136 taxa (29\%) while other important contributions are provided by the Mediterranean sensu lato plants (100 taxa, 22\%) and the Asian (55 taxa, 12\%) (Fig. 5). The Mann-Whitney test confirmed no significant differences between the medians of the samples considered $(\mathrm{U}=9, \mathrm{p}=1,0000)$.

Invasive units of the Sardinian alien flora are mostly of American (35 taxa, 55\%) and South African origin (11 taxa, $17 \%)$. With regard to the invasive flora from Corsica, the most represented element is also the American (53 taxa, 53\%), followed by the South African (16 taxa, 16\%) (Fig. 5). MannWhitney test confirmed no significant differences between the medians of the samples considered $(U=9, p=0,8595)$.

Concerning the ways of introduction, taxa that are cultivated as ornamental are far the most frequent in the Sardinian alien flora, counting 247 entities (49\%), followed by crops, with 125 taxa (24\%), while seed contaminant taxa account for up to 59 (12\%), hitchhikers $39(8 \%)$ and forestry 38 (7\%) (Fig. 6). As far as Sardinian invasive taxa are concerned, ornamental units still represent the most numerous group with 27 taxa (42\%), while there is a net decrease of the crops and an increase of the seed contaminants and of hitchhikers (Fig. 7). In Corsica the ornamental and agricultural paths are also the ways of introduction that provide more than half of the whole alien flora [208 (45\%) and 117 taxa (25\%) respectively], while similar and much more modest contributions come from hitchhikers and seed contaminant taxa and a very low quota of taxa introduced for forestry (Fig. 6). When only taking the invasive units into account, the ornamental component in Corsica is represented by 60 taxa (61\%), followed by seed contaminants (14taxa, 14\%) and by hitchhikers (13 taxa, 13\%) (Fig. 7).

For the situation of alien taxa in general and in the specific case of invasive units, the Mann-Whitney test confirmed no significant differences between the medians of the samples considered $(U=6, p=0,8102)$ and $(U=5, p=1,0000)$ respectively.

The analysis of the habitats occupied by alien taxa in Sardinia shows that synanthropic environments are those where alien units are found more frequently (206 taxa, 40\%), followed by agricultural habitats with 106 taxa (21\%), while the remaining ones provide minor and nearly comparable contributions, with the exception of matorrals, that account for only 13 taxa (3\%). In Sardinia invasive taxa tend to invade mostly synanthropic habitats (29 taxa, 45\%) and at a lesser extent wetlands and coastal habitats. A similar situation is seen in Corsica, where the habitats that aliens tend to occupy are commonly synanthropic (222 taxa, 48\%), followed by agricultural lands (87 taxa, 19\%). These data are coincident with the highest number of invasive taxa in Corsica, that occur in synanthropic habitats (46 taxa, 46\%). By contrast, important differences regarding agricultural habitats are found, when comparing alien and invasive Corsican flora, with a decrease to $14 \%$ ( 5 taxa). Important differences are also found in wetlands and coasts, where invasive units nearly double their percentage (17 taxa (17\%) and 15 taxa (15\%) respectively) (Fig. 8). The Mann-Whitney test confirmed no significant differences between the medians of the samples considered (U $=7, p=0,7983)$ and $(U=7, p=1,0000)$ for the general and only invasive cases respectively.

\section{Discussion}

The alien vascular flora of Sardinia and Corsica constitutes the $18 \%$ and $17 \%$ of the total vascular flora of each island, respectively. These data are consistent with those observed in other contexts of the Mediterranean islands, e.g., the Balearic Islands (19\%, Podda et al., 2010), and are significantly higher than those reported for Sicily (12.55\%, Raimondo et al., 2010) and for the Tuscan Archipelago (10\%, Lazzaro et al., 2014).

The prevalence of invasive neophytes on archeophytes, is evident in both islands, with an outstanding higher proportion in Corsica, although the territory is mostly mountainous and smaller than that of Sardinia. The high disproportion of invasive taxa found between neophytes and archeophytes also characterizes other contexts such as the Balearic Islands (Podda et al., 2011) and the Tuscan Archipelago (Lazzaro et al., 2014). In the case of the Balearic Islands (14\% of invasive taxa) and the Tuscan Archipelago (22\% of invasive taxa), the proportion of such invasive entities is higher than in Sardinia and Corsica. This fact could be attributed to the greater anthropization of the territories than those analysed in this paper.

Among the invasive units common to the two islands, some are also spread worldwide [Acacia mearnsii De Willd., Ailanthus altissima (Mill.) Swingle, Arundo donax L., Carpobrotus edulis (L.) N.E. Br., Cortaderia selloana (Schult. \& Schult. F.) Asch. \& Graebn., etc.], or around Europe ( $A$. altissima, $C$. edulis, $C$. selloana, Cyperus eragrostis Lam. non Vahl., etc.) (DAISIE, 2009), and there are others that are emerging in other countries with a similar (Mediterraneanlike) climate to Sardinia and Corsica. These include Agave americana L. (Badano and Puignaire, 2004; Smith and Figueiredo, 2007), Asclepias fruticosa L. (Fernández Haeger et al., 2010), Cotula coronopifolia L. (Brunel et al., 2010), Malephora crocea Schwantes (Cal-IPC, 2006) and Phytolacca americana L. (Dumas, 2011).

With regard to the plant families, Asteraceae, Poaceae and Fabaceae, are the most represented when considering the alien flora as a whole, while if taking into consideration only the invasive component, a relatively high contribution from the 
344

Solanaceae, Amaranthaceae and Aizoaceae families has been recorded. These values are consistent with what has been observed in other Mediterranean islands and archipelagos, such as the Balearic Islands and the Tuscan Archipelago (Podda $e t$ al., 2011; Lazzaro et al., 2014) and in the continent, as Spain (Sanz Elorza et al., 2004).

When considering the life forms that characterize both the alien and invasive component of Sardinia and Corsica, the predominance of phanerophytes -mainly introduced for reforestation, forestation and ornamental use-, of therophytes spread as seed contaminants, due to the degradation of habitats and fires- and, to a lesser extent of hemicryptophytes, were also observed in other islands, such as the Balearic (Podda et al., 2010) and the Tuscan Archipelago (Lazzaro et al., 2014) and continental areas, like Spain (Sanz Elorza et al., 2004). The substantial contribution of geophytes is due to their mechanisms of adaptation and resistance to fire, very common in the Mediterranean area. This situation is to be interpreted on the basis of an extended period of summer drought representative of the Mediterranean climates, usually occurring as a particularly long period that obviously leads to a strong selection in favour of arboreal and annual habitus (Lloret $e t a l$, 2004; Allen, 2001) or of just the arboreal component, based on the massive use for ornamental purposes, as already reported by Richardson and Rejmanek (2011).

The American predominance featuring alien flora -invasive and not invasive- of Sardinia and Corsica, is a constant in many Mediterranean areas, both islands -such as the Balearic Islands (Podda et al., 2011, 2010), Crete (Dal Cin D 'Agata et al., 2009) and the Tuscan Archipelago (Lazzaro et al., 2014)- and continental, as Spain (Sanz Elorza et al., 2004) and Greece (Arianoutsou et al., 2010). Other relatively important contributions to the exotic flora of Sardinia and Corsica, as for the other mentioned territories, come from Asia, from the Mediterranean basin and the African continent; with respect to the invasive flora, it is to be noted that the Mediterranean component is significantly reduced. In light of what emerges from the analysis of introduction pathways in Sardinia and Corsica as well as in other Mediterranean contexts (Lazzaro et al., 2014; Podda et al., 2010; Sanz Elorza et al., 2004), the greater invasiveness that characterizes neophytes has been confirmed, associated to intentional introductions, in particular to the entities cultivated for ornamental purposes.

The analysis of the habitats where the largest number of alien taxa occur, or where some of these plants show an increased invasiveness indicates, as noted above for other territories (Podda et al., 2010; Sanz Elorza et al., 2004), that one of the basic factors explaining the arrival of non-indigenous entities, of their permanence in the two islands and their possible tendency to invade, is the loss of wilderness, phenomenon usually favoured by human activities and by changes in land use, as revealed in synanthropic and ruderal habitats. In contrast, although aquatic, coastal and riparian habitats host a relatively small number of alien taxa, it is equally true that being these habitats clearly marked by similar ecological conditions regardless of geographical and climatic conditions, these habitats are particularly susceptible to invasions and suffer the presence of some of the most invasive entities of both islands (Blondel and Médail, 2009; Mascia et al., 2009; Nucci et al., 2012; Schnitzler et al., 2007; Zedler and Kercher, 2004). Instead, the habitats less susceptible to invasions are matorrals, typically Mediterranean habitats with greater resilience (Di Castri, 1991).

\section{Conclusions}

Although there are important differences in the size and geography, as well as in the number of alien taxa present in the two islands, the analysis of the two alien floras shows a remarkable consistency between the two islands on the various aspects analysed. Nevertheless, in light of the high proportion of alien entities that characterizes the flora of Sardinia and Corsica, it is reasonable to speak of a full-scale invasion. In this sense, although it is possible to lead back at least part of the competitive success of some alien taxa -linked to their ability to settle down in anthropic environments, it is undeniable that other natural habitats, such as wetlands and coastal areas, are particularly sensitive to the entry of alien and in particular invasive entities. Therefore, a need for greater combined efforts, both geographically, and with regard to the various thematic areas of the phenomenon of biological invasions is necessary, in order to address the issue of the presence and the increasing danger of alien plant taxa through similar actions and common conservation policies.

\section{Acknowledgements}

This work was supported by the Provincia di Cagliari Assessorato Tutela Ambiente, Agenzia Forestas and Regione Autonoma della Sardegna - Assessorato Difesa Ambiente (Italy) and by the Territorial Collectivity of Corsica and the French Ministry of Environment, Energy and the Sea. The authors would like to thank the CCB and CBNC staff for technical support. In particular, V. Lazzeri and F. Mascia helped with specimens collecting.

\section{References}

Allen HD (2001). Mediterranean ecogeography. Pearson Education Limited, Edinburgh.

Arianoutsou M, Bazos I, Delipetrou P, Kokkoris Y (2010). The alien flora of Greece: taxonomy, life traits and habitat preferences. Biological Invasions 12:3525-3549.

Bacchetta G, Fenu G, Mattana E (2012). A checklist of the exclusive vascular flora of Sardinia with priority rankings for conservation. Anales del Jardín Botánico de Madrid 69:81-89.

Bacchetta G, Iiriti G, Pontecorvo C (2005). Contribution to the knowledge of the Sardinia endemic vascular flora. Informatore Botanico Italiano 37:306-307 (in Italian).

Badano EI, Pugnaire FI (2004). Invasion of Agave species (Agavaceae) in south-east Spain: invader demographic parameters and impacts on native species. Diversity and Distributions 10:493-500.

Blondel J, Médail F (2009). Biodiversity and conservation. In: Woodward JC (Ed). The Physical Geography of the Mediterranean. Oxford University Press, Oxford pp 615-650.

Brunel S, Schrader G, Brundu G, Fried G (2010). Emerging invasive alien plants for the Mediterranean Basin. EPPO Bulletin 40(2):219-238.

Cal-IPC (2006). California Invasive Plant Inventory. Berkeley (CA): California Invasive Plant Council. Cal-IPC Publication 2006-02. (www.cal-ipc.org). 
Cañadas EM, Fenu G, Peñas J, Lorite J, Mattana E, Bacchetta G (2014). Hotspots within Hotspots: endemic Plant Richness, Environmental Drivers, and Implications for Conservation. Biological Conservation 170:282-291.

Chase MW, Reveal JL (2009). A phylogenetic classification of the land plants to accompany APG III. Botanical Journal of the Linnean Society 161:122-127.

Christenhusz MJM, Zhang XC, Schneider H (2011a). A linear sequence of extant families and genera oflycophytes and ferns. Phytotaxa 19:7-54.

Christenhusz MJM, Reveal JL, Farjon A, Gardner MF, Mill RR, Chase MW (2011b). A new classification and linear sequence of extant gymnosperms. Phytotaxa 19:55-70.

Conservatoire Botanique National de Corse (2014). Catalogue des Trachéophytes de Corse. CBNC pp 153.

Conti F, Abbate G, Alessandrini A, Blasi C (Eds) (2005). An Annoted Checklist of the Italian Vascular Flora. Palombi Editori, Roma.

Conti F, Alessandrini A, Bacchetta G, Banfi E, Barberis G, Bartolucci F, ... Vidali M (2007). Additions to the checklist of the Italian vascular flora. Natura Vicentina 10:5-74(in Italian).

DAISIE (2009). The Handbook of Alien Species in Europe. Invading Nature:SpringerSeries in Invasion Ecology.Springer. Amsterdam.

Dal Cin D'Agata C, Skoula M, Brundu G (2009). A preliminary inventory of the alien flora of Crete (Greece). Bocconea 23:301-315.

Delbosc P (2015). Phytosociologie dynamico-caténale des végétations de la Corse: méthodologies typologique et cartographique. Thèse de doctorat, Université de Bretagne Occidentale.

Di Castri F (1991). An ecological overview of the five regions of the world with Mediterranean climate. In: Groves RH, Di Castri F (Eds). Biogeography of Mediterranean invasions. Cambridge University Press, Cambridgepp 3-15.

Dumas Y (2011). American grape (Phytolacca americana): an invasive alien species. RenDez-Vous Techniques 33/34:47-57.

Euro+Med (2006-onwards). Euro+Med PlantBase - the information resource for Euro-Mediterranean plant diversity. Retrieved 2016 January 15 from http://ww2.bgbm.org/EuroPlusMed/.

Fenu G, Fois M, Cañadas EM, Bacchetta G (2014). Using Endemic-plant Distribution, Geology and Geomorphology in Biogeography: the Case of Sardinia (Mediterranean Basin). Systematics and Biodiversity 12:181193.

Fernández Haeger J, Jordano Barbudo D, León Meléndez M, Devesa JA (2010). Gomphocarpus R. BR (Apocynaceae subfam. Asclepiadoideae) en Andalucía occidental. Lagascalia 30:39-46.

Genovesi P, Shine C (2004) European Strategy on Invasive Alien Species. Nature and Environment No. 137, Council of Europe Publishing, Strasbourg.

Hulme PE, Brundu G, Camarda I, Dalias P, Lambdon P, Lloret F, ... Vilà M (2008). Assessing the risks to Mediterranean islands ecosystems from alien plant introductions, 39-56 p. In: Tokarska-Guzik B et al. (Eds). Plant invasions: human perception, ecological impacts and management. Backhuys Publishers, Leiden.

Jeanmonod D, Gamisans J (2013). Flora Corsica. 2nd rev and augmented edition. Bulletin dela Sociétébotanique. Centre-Ouest, NoSpécial 39.

Jeanmonod D, Naciri Y, Schlüssel A, Gamisans J (2015). Floristic analyses of the Corsican flora: biogeographical origin and endemism. Candollea 70(1):21-41.

Jeanmonod D, Schlüssel A, Gamisans J (2011). Status and trends in the alien flora of Corsica. EPPO Bulletin 41(1):85-99.

Lambdon PW, Pyšek P, Basnou C, Hejda M, Ariannoutsou M, Essl F, ... Hulme P (2008). Alien flora of Europe: species diversity, temporal trends, geographical patterns and research needs. Preslia 80:101-149.

Lazzaro L, Ferretti G, Giuliani C, Foggi B (2014). A checklist of the alien flora of the Tuscan Archipelago (Italy). Webbia: Journal of Plant Taxonomy and Geography 69(1):157-176.

Lloret F, Médail F, Brundu G, Hulme PE (2004). Local and regional abundance of exotic plant species on Mediterranean islands: are species traits important? Global Ecology Biogeography 13:37-45.

Mack RN, Simberloff D, Lonsdale WM, Evans H, Clout M, Bazzaz FA (2000). Biotic invasions: causes, epidemiology, global consequences, and control.Ecological Applications 10:689-710.

Mascia F, Podda L, Bacchetta G (2009). Alien flora in temporary ponds of Sardinia: preliminary data on invasive species and threatened habitats. Proceedings International Conference Mediterranean Temporary Ponds Minorca.

Médail F, Quézel P (1997). Hot-spots analysis for conservation of plant biodiversity in the Mediterranean Basin. Annals of the Missouri Botanical Garden 84:112-127.

Médail F, Quézel P (1999). Biodiversity Hotspots in the Mediterranean Basin: Setting Global Conservation Priorities. Conservation Biology 13(6):1510-1513.

Médail F, Diadema K (2009). Glacial refugia influence plant diversity patterns in the Mediterranean Basin. Journal of Biogeography 36(7):1333-1345.

Millennium Ecosystem Assessment (2005). Ecosystems and Human Wellbeing: Biodiversity Synthesis. World Resources Institute, Washington DC.

Miller C, Kettunen M, Shine C (2006). Scope options for EU action on invasive alien species (IAS). Final report for the European Commission. Institute for European Environmental Policy(IEEP), Brussels.

Nucci A, Angiolini C, Landi M, Bacchetta G (2012). Regional and local patterns of riparian flora: Comparison between insular and continental Mediterranean rivers. Écoscience 19(3):213-224.

PignattiS (1982). Flora of Italy 1-3.Edagricole, Bologna (in Italian).

Podda L, Fraga I, Arguimbau P, Mayoral Garca-Berlanga O, Mascia F, Bacchetta $G$ (2010). Comparacion de la flora exotica vascular en sistemas de islas continentales: Cerdena (Italia) y Baleares (Espana). Anales del Jardín Botánico de Madrid 67(2):157-176.

Podda L, Fraga I, Arguimbau P, Mascia F, Mayoral García-Berlanga O, Bacchetta G (2011). Comparison of the invasive alien flora in continental islands: Sardinia (Italy) and Balearic Islands (Spain). RendicontiScienze Fisichee Naturali Accademia Lincei22(1):31-45.

Podda L, Lazzeri V, Mascia F, Mayoral Garcia-Berlanga O, Bacchetta G (2012). The Checklist of the Sardinian Alien Flora: an Update. Notulae Botanicae Horti Agrobotanici Cluj-Napoca 40(2):1421.

Pyšek P, Richardson DM, Rejmánek M, Webster GL, Williamson M, Kirschner J (2004). Alien plants in checklist and floras: towards better communication between taxonomist and ecologists. Taxon 53(1):131-143. 
346

Raimondo FM, Domina G, Spadaro V (2010). Checklist of the vascular flora of Sicily. Quaderni Botanica Ambientale Applicata21:189-252.

Raunkiaer C (1934). The life forms of plants and statistical plant geography. Univ Oxford, Oxford.

Richardson DM, Pyšek P, Rejmánek M, Barbour MG, Panetta FD, West CJ (2000). Naturalization and invasion of alien plants: Concepts and definitions. Diversity and Distributions 6:93-107.

Richardson DM, Rejmánek M (2011). Trees and shrubs as invasive alien species - a global review. Diversity and Distributions 17:788-809.

Sala OE, Chapin FS, Armesto JJ, Below E, Bloomfield J, Dirzo R, ... Wall $\mathrm{DH}$ (2000). Global biodiversity scenarios for the year 2100 . Science 287:1770-1774.

Sanz Elorza M, Dana SánchezED, Sobrino VesperinasE(Eds) (2004). Atlas de las Plantas Alóctonas Invasoras en España. Dirección General para la Biodiversidad, Madrid.

Sax DF, Gaines SD (2008). Species invasions and extinction: the future of native biodiversity on islands. Proceedings of the National Academy of Sciences 105(Suppl 1):11490-11497.

Schnitzler A, Hale BW, Alsum EM (2007). Examining native and exotic species diversity in European riparian forests. Biological Conservation 138:146-156.

Smith GF, Figueiredo E (2007). Naturalized species of Agave l. (Agavaceae) on the southeastern coast of Portugal. Haseltonia 13:52-60.

Stevens PF (2001-onwards). Angiosperm Phylogeny Website. Version 12, July 2012. Retrieved 2016 February 1 from http://www.mobot.org/MOBOT/research/APweb/.
The Plant List (2013). Version 1.1. Retrieved 2016 February 20 from http://www.theplantlist.org/.

Thompson, JD (2005). Plant evolution in the Mediterranean. Oxford University Press, Oxford UK.

Vacca A, Loddo S, Serra G, Aru A (2002). Soil degradation in Sardinia (Italy): main factors and processes. In: Zdruli P, Steduto P, Kapur S (Eds). 7. International meeting on Soils with Mediterranean Type of Climate (selected papers). Bari: CIHEAM, 2002 (Options Méditerranéennes: Série A. Séminaires Méditerranéens; n. 50).

Vilà M, Espinar JL, Hejda M, Hulme PE, Jaroŝlk V, Maron JL, ... Pyŝek P (2011). Ecological impacts of invasive alien plants: a meta-analysis of their effects on species, communities and ecosystems. Ecology Letters 14:702-708.

Vitousek PM (1990). Biological invasions and ecosystem processes: Toward an integration of population biology and ecosystem studies. Oikos 57:713.

Winter M, Schweiger O, Klotz S, Nentwig W, Andriopoulos P, Arianoutsou M, ... Kühn I (2009). Plant extinctions and introductions lead to phylogenetic and taxonomic homogenization of the European flora. Proceedings of the National Academy of Sciences 106(51):2172121725 .

Zachos FE, Habel CJ (Eds) (2011). Biodiversity hotspots. Distribution and protection of conservation priority areas. Berlin: Springer Verlag.

Zedler JB, Kercher S (2004). Causes and consequences of invasive plants in wetlands: opportunities, opportunists, and outcomes. Critical Review in PlantSciences 23(5):431-452. 
Comparative analysis of the exotic vascular flora of Sardinia (Italy) and Corsica (France)

For Sardinia: * new report taxa respect to the previous checklist (Podda et al., 2012), ** new taxa from other authors

For Corsica: *** new taxa respect to the previous checklist (Jeanmonod et al., 2013), **** new reports

\begin{tabular}{|c|c|c|c|c|c|c|c|c|c|}
\hline $\mathbf{N}^{\circ}$ & Family & Taxon & $\begin{array}{c}\text { Sardinia } \\
\text { presence/ } \\
\text { Doubtful } \\
\text { presence } \\
\text { (D) }\end{array}$ & $\begin{array}{c}\text { Corsica } \\
\text { presence/ } \\
\text { Doubtful } \\
\text { presence } \\
\text { (D) }\end{array}$ & $\begin{array}{c}\text { Archaeophyte } \\
\text { (Arch)/ Neophyte } \\
\text { (Neo)/ Doubtful } \\
\text { alien (Da) } \\
\text { Sardinia }\end{array}$ & $\begin{array}{c}\text { Archaeophyte } \\
\text { (Arch)/ Neophyte } \\
\text { (Neo)/ Doubtful } \\
\text { alien (Da) } \\
\text { Corsica }\end{array}$ & $\begin{array}{c}\text { Status } \\
\text { Sardinia }\end{array}$ & $\begin{array}{l}\text { Status } \\
\text { Corsica }\end{array}$ & Habitat \\
\hline 1 & Acanthaceae & Acanthus mollis $\mathrm{L}$. & 1 & 1 & Arch & Arch & Inv & Inv & Synanthropic \\
\hline 2 & Acanthaceae & **Ruellia simplex $\mathrm{C}$. Wright & 1 & & $\mathrm{Neo}$ & & Cas & & Synanthropic \\
\hline 3 & Actinidiaceae & ****Actinidia deliciosa (A. Chev.) C.F. Liang \& A.R. Ferguson & & 1 & & $\mathrm{Neo}$ & & Cas & Agricultural \\
\hline 4 & Aizoaceae & Carpobrotus acinaciformis (L.) L. Bolus & 1 & 1 & $\mathrm{Neo}$ & Neo & Inv & Inv & Coastal \\
\hline 5 & Aizoaceae & Carpobrotus edulis (L.) N.E. Br. & 1 & 1 & $\mathrm{Neo}$ & $\mathrm{Neo}$ & Inv & Inv & Coastal \\
\hline 6 & Aizoaceae & Drosanthemum floribundum (Haw.) Schwantes & 1 & & $\mathrm{Neo}$ & & Nat & & Coastal \\
\hline 7 & Aizoaceae & Lampranthus brownii (Hook. f.) N.E. Br. & & 1 & & $\mathrm{Neo}$ & & Nat & Coastal \\
\hline 8 & Aizoaceae & Lampranthus elegans (Jacq.) Schwantes & 1 & & $\mathrm{Neo}$ & & Inv & & Coastal \\
\hline 9 & Aizoaceae & $\begin{array}{l}\text { ****Malephora crocea Schwantes var. purpureo-crocea (Haw.) H. } \\
\text { Jacobsen \& Schwantes }\end{array}$ & 1 & 1 & Neo & $\mathrm{Neo}$ & Inv & Inv & Coastal \\
\hline 10 & Aizoaceae & Malephora lutea Schwantes & 1 & & $\mathrm{Neo}$ & & Cas & & Coastal \\
\hline 11 & Aizoaceae & Malephora uitenhagensis (L. Bol.) Jacobsen et Schwantes & 1 & & $\mathrm{Neo}$ & & Cas & & Coastal \\
\hline 12 & Aizoaceae & Mesembryanthemum cordifolium $\mathrm{L}$. f. & 1 & 1 & $\mathrm{Neo}$ & $\mathrm{Neo}$ & Inv & Inv & Coastal \\
\hline 13 & Aizoaceae & Mesembryanthemum cristallinum $\mathrm{L}$. & 1 & 1 & $\mathrm{Neo}$ & $\mathrm{Da}$ & Nat & Nat & Coastal \\
\hline 14 & Aizoaceae & Mesembryanthemum nodiflorum $\mathrm{L}$. & 1 & & $\mathrm{Neo}$ & & Nat & & Coastal \\
\hline 15 & Aizoaceae & Ruschia tumidula (Haw.) Schwantes & 1 & & $\mathrm{Neo}$ & & Nat & & Coastal \\
\hline 16 & Aizoaceae & *Tetragonia tetragonoides (Pall.) Kuntze & 1 & 1 & $\mathrm{Neo}$ & $\mathrm{Neo}$ & Cas & Cas & Coastal \\
\hline 17 & Alismataceae & *Damasonium bourgaei Coss. & 1 & & $\mathrm{Da}$ & & Nat & & Wetlands \\
\hline 18 & Alismataceae & Sagittaria sagittifolia $\mathrm{L}$. & & 1 & & $\mathrm{Da}$ & & Cas & Riparian \\
\hline 19 & Amaranthaceae & Achyranthes aspera $\mathrm{L}$. & 1 & & $\mathrm{Neo}$ & & Nat & & Matorrals \\
\hline
\end{tabular}




$\begin{array}{ll}20 & \text { Amaranthaceae } \\ 21 & \text { Amaranthaceae } \\ 22 & \text { Amaranthaceae } \\ 23 & \text { Amaranthaceae } \\ 24 & \text { Amaranthaceae } \\ 25 & \text { Amaranthaceae } \\ 26 & \text { Amaranthaceae } \\ 27 & \text { Amaranthaceae } \\ 28 & \text { Amaranthaceae } \\ 29 & \text { Amaranthaceae } \\ 30 & \text { Amaranthaceae } \\ 31 & \text { Amaranthaceae } \\ 32 & \text { Amaranthaceae } \\ 33 & \text { Amaranthaceae } \\ 34 & \text { Amaranthaceae } \\ 35 & \text { Amaranthaceae } \\ 36 & \text { Amaranthaceae } \\ 37 & \text { Amaryllidaceae } \\ 38 & \text { Amaryllidaceae } \\ 39 & \text { Amaryllidaceae } \\ 40 & \text { Amaryllidaceae } \\ 41 & \text { Amaryllidaceae } \\ 42 & \text { Amaryllidaceae } \\ 43 & \text { Amaryllidaceae } \\ 44 & \text { Amaryllidaceae } \\ 45 & \text { Amaryllidaceae } \\ 46 & \text { Amaryllidaceae } \\ 47 & \text { Amaryllidaceae } \\ 48 & \text { Amaryllidaceae } \\ & \end{array}$

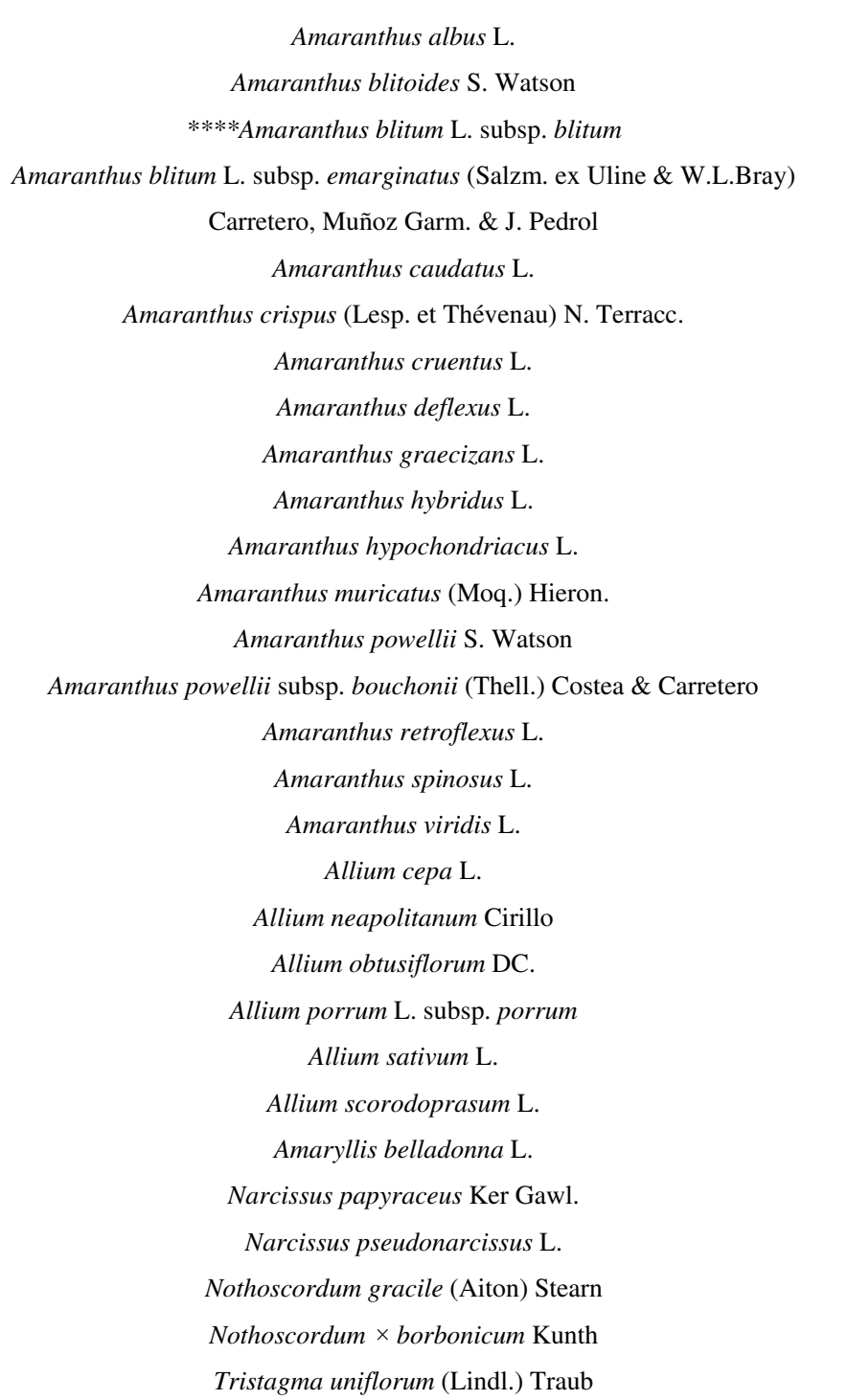

\begin{tabular}{|c|c|c|c|c|c|c|}
\hline 1 & 1 & Neo & $\mathrm{Neo}$ & Inv & Inv & Agricultural \\
\hline \multirow[t]{2}{*}{1} & 1 & Neo & $\mathrm{Neo}$ & Nat & Nat & Synanthropic \\
\hline & 1 & & Neo & & Nat & Synanthropic \\
\hline 1 & 1 & $\mathrm{Neo}$ & Neo & Nat & Cas & Synanthropic \\
\hline 1 & & $\mathrm{Neo}$ & & Nat & & Agricultural \\
\hline 1 & & Neo & & Cas & & Agricultural \\
\hline 1 & 1 & Neo & Neo & Inv & Nat & Synanthropic \\
\hline 1 & 1 & Neo & Neo & Inv & Nat & Synanthropic \\
\hline 1 & & Arch & & Nat & & Synanthropic \\
\hline 1 & 1 & $\mathrm{Neo}$ & $\mathrm{Neo}$ & Nat & Nat & Synanthropic \\
\hline 1 & 1 & $\mathrm{Neo}$ & $\mathrm{Neo}$ & Cas & Nat & Synanthropic \\
\hline \multirow[t]{3}{*}{1} & & $\mathrm{Neo}$ & & Inv & & Synanthropic \\
\hline & 1 & & Neo & & Nat & Synanthropic \\
\hline & 1 & & Neo & & Nat & Synanthropic \\
\hline \multirow[t]{2}{*}{1} & 1 & Neo & $\mathrm{Neo}$ & Inv & Inv & Synanthropic \\
\hline & 1 & & $\mathrm{Neo}$ & & Cas & Agricultural \\
\hline 1 & 1 & Neo & Neo & Inv & Nat & Synanthropic \\
\hline \multirow[t]{3}{*}{1} & & Arch & & Nat & & Agricultural \\
\hline & 1 & & $\mathrm{Da}$ & & & Synanthropic \\
\hline & 1 & & $\mathrm{Neo}$ & & Cas & Wetlands \\
\hline D & 1 & Arch & $\mathrm{Neo}$ & Cas & Cas & Agricultural \\
\hline \multirow[t]{3}{*}{1} & & Arch & & Cas & & Agricultural \\
\hline & 1 & & $\mathrm{Neo}$ & & Cas & Agricultural \\
\hline & 1 & & $\mathrm{Neo}$ & & Cas & Synanthropic \\
\hline 1 & & $\mathrm{Da}$ & & Nat & & Synanthropic \\
\hline 1 & & Arch & & Nat & & Synanthropic \\
\hline 1 & & $\mathrm{Neo}$ & & Nat & & Synanthropic \\
\hline D & 1 & $\mathrm{Neo}$ & $\mathrm{Neo}$ & & Inv & Synanthropic \\
\hline 1 & 1 & $\mathrm{Neo}$ & $\mathrm{Neo}$ & Cas & Nat & Synanthropic \\
\hline
\end{tabular}




Anacardiaceae
Anacardiaceae
Anacardiaceae
Anacardiaceae
Anacardiaceae
Apiaceae
Apiaceae
Apiaceae
Apiaceae
Apiaceae
Apiaceae
Apiaceae
Apiaceae
Apiaceae
Apiaceae
Apiaceae
Apiaceae
Apiaceae
Apiaceae
Apiaceae
Apiaceae
Apocynaceae
Apocynaceae
Apocynaceae
Apocynaceae
Apocynaceae
Araceae
Araceae
Araceae

Rhus coriaria $\mathrm{L}$.

Rhus laevigata $\mathrm{L}$.

Rhus typhina $\mathrm{L}$.

Schinus molle $\mathrm{L}$.

**Schinus terebinthifolia Raddi

Anethum graveolens $\mathrm{L}$.

Anthriscus cerefolium (L.) Hoffm.

Apium graveolens $\mathrm{L}$.

Bupleurum odontites $\mathrm{L}$.

*Bupleurum rotundifolium $\mathrm{L}$.

Coriandrum sativum $\mathrm{L}$

Cyclospermum leptophyllum (Pers.) Britton \& Wilson

Daucus carota subsp. sativus Schübl. \& G. Martens

Ferula arrigonii Bocchieri

Levisticum officinale W. D. J. Koch

Magydaris pastinacea (Lam.) Paol.

Orlaya grandiflora (L.) Hoffm.

Pastinaca sativa L. subsp. sativa var. sativa

Petroselinum crispum (Mill.) Fuss

Pimpinella anisum $\mathrm{L}$.

Thapsia villosa $\mathrm{L}$

Araujia sericifera Brot.

Asclepias fruticosa $\mathrm{L}$.

Asclepias syriaca $\mathrm{L}$.

Catharanthus roseus (L.) G. Don

$$
\text { Vinca major } \mathrm{L} \text {. }
$$

Chamaerops humilis L.

Colocasia esculenta (L.) Schott

Dracunculus vulgaris Schott
Arch

Neo

Neo

$\mathrm{Neo}$

Neo

Arch

Arch

Arch

D

Arch

Arch

Neo

$\mathrm{Da}$

Neo

Arch
(1)

Neo

$\mathrm{Neo}$

Arch

Da

Arch

Da

Arch

Arch

Arch

Arch

Arch

Neo

Neo

Neo

Nat

Cas

Cas

Cas

Cas

Cas

Nat

Cas

Nat

Cas

.

Ca

Cas
Cas

Nat
Agricultural

Synanthropic

Synanthropic

Synanthropic

Synanthropic

Agricultural

Synanthropic

Riparian

Matorrals

Agricultural

Matorrals

Agricultural

Coastal

Synanthropic

Synanthropic

Synanthropic

Synanthropic

Agricultural

Agricultural

Synanthropic

Synanthropic

Riparian

Synanthropic

Synanthropic

Synanthropic

Matorrals

Riparian

Nat Synanthropic 


Araceae
Araceae
Araceae
Araceae
Araceae
Araliaceae
Araliaceae
Araliaceae
Arecaceae
Arecaceae
Arecaceae
Arecaceae
Arecaceae
Arecaceae
Aristolochiaceae
Asclepiadaceae
Asparagaceae
Asparagaceae
Asparagaceae
Asparagaceae
Asparagaceae
Asparagaceae
Asparagaceae
Asparagaceae
Asparagaceae
Asparagaceae
Asparagaceae
Asparagaceae
Asparagaceae

Lemna aequinoctialis Welw.

Lemna minuta Kunth

Lemna valdiviana Phil.

****Pistia stratiotes $\mathrm{L}$

Zantedeschia aethiopica (L.) Spreng.

***Hedera helix subsp. maroccana (McAll.) Fennane

Hedera helix L. subsp. poëtarum (Bertol.) Nyman

$$
\text { Hydrocotyle ranunculoides } \mathrm{L} \text {. } \mathrm{f} \text {. }
$$

Phoenix canariensis Chabaud

Phoenix dactylifera $\mathrm{L}$.

Raphia farinifera (Gaertn.) Hylander

Trachycarpus fortunei (Hook.) H. Wendl.

Washingtonia filifera (Linden ex André) H.Wendl. ex de Bary

****Washingtonia robusta $\mathrm{H}$. Wendl.

Aristolochia sempervirens $\mathrm{L}$.

Periploca graeca $\mathrm{L}$.

Agave americana L. var. americana

Agave attenuata Salm-Dick

Agave fourcroydes Lem.

Agave ingens A. Berger

Agave salmiana Otto ex Salm-Dyck

Agave salmiana var. ferox (K. Koch) Gentry

Agave sisaliana Perrine

**Asparagus aethiopicus $\mathrm{L}$.

Asparagus asparagoides (L.) Druce

Asparagus officinalis L. subsp. officinalis

Asparagus setaceus (Kunth) Jessop

Convallaria majalis $\mathrm{L}$.

Hyacinthus orientalis $\mathrm{L}$.
$\mathrm{Neo}$

$\mathrm{Neo}$

Neo

Neo

Arch

Neo

Neo

Arch

Neo

Neo

Neo

Neo

Arch

Neo

Neo

Neo

Neo

Neo

Neo

$\mathrm{Neo}$

$\mathrm{Neo}$

$\mathrm{NeO}$

Arch

Neo

Arch
Cas

Inv

Cas

Neo

$\mathrm{Neo}$

Neo

$\mathrm{Neo}$

$\mathrm{NeO}$

.

Neo

$\mathrm{Neo}$

Da

$\mathrm{Neo}$

Neo

Neo

Neo

Da

Da

Arch
Wetlands

Wetlands

Wetlands

Wetlands

Riparian

Synanthropic

Riparian

Wetlands

Wetlands

Synanthropic

Agricultural

Synanthropic

Synanthropic

Synanthropic

Synanthropic

Wetlands

Coastal

Coastal

Coastal

Coastal

Coastal

Coastal

Coastal

Synanthropic

Inv Synanthropic

Agricultural

Synanthropic

Synanthropic

Synanthropic 


$\begin{array}{ll}107 & \text { Asparagaceae } \\ 108 & \text { Asparagaceae } \\ 109 & \text { Asparagaceae } \\ 110 & \text { Asparagaceae } \\ 111 & \text { Asparagaceae } \\ 112 & \text { Asparagaceae } \\ 113 & \text { Asparagaceae } \\ 114 & \text { Asparagaceae } \\ 115 & \text { Asparagaceae } \\ 116 & \text { Asteraceae } \\ 117 & \text { Asteraceae } \\ 118 & \text { Asteraceae } \\ 119 & \text { Asteraceae } \\ 120 & \text { Asteraceae } \\ 121 & \text { Asteraceae } \\ 122 & \text { Asteraceae } \\ 123 & \text { Asteraceae } \\ 124 & \text { Asteraceae } \\ 125 & \text { Asteraceae } \\ 126 & \text { Asteraceae } \\ 127 & \text { Asteraceae } \\ 128 & \text { Asteraceae } \\ 129 & \text { Asteraceae } \\ 130 & \text { Asteraceae } \\ 131 & \text { Asteraceae } \\ 132 & \text { Asteraceae } \\ 133 & \text { Asteraceae } \\ 134 & \text { Asteraceae } \\ 135 & \text { Asteraceae } \\ & \end{array}$

Melomphis arabica (L.) Raf.

Muscari armeniacum Baker

Nectaroscilla hyacinthoides (L.) Parl.

Oncostema peruviana (L.) Speta

Ornithogalum divergens Boreau

Stellarioides canaliculata Medik.

Yucca aloifolia $\mathrm{L}$.

****Yucca filamentosa $\mathrm{L}$.

****Yucca gloriosa $\mathrm{L}$

Achillea millefolium $\mathrm{L}$. subsp. millefolium

Ageratina adenophora (Spreng.) R. M. King \& H. Rob.

Ambrosia artemisiifolia $\mathrm{L}$.

****Anthemis cretica $\mathrm{L}$.

Arctotheca calendula (L.) Levyn

Argyranthemum frutescens (L.) Sch. Bip. subsp. frutescens

Artemisia absinthium $\mathrm{L}$.

**Artemisia aпnиа $\mathrm{L}$

Artemisia arborescens (Vaill.) L.

Artemisia verlotiorum Lamotte

Bidens aureus (Ait.) Sherff

Bidens frondosus $\mathrm{L}$.

**Bidens pilosus $\mathrm{L}$.

Bidens radiatus Thuill.

Bidens subalternans DC.

Calendula officinalis $\mathrm{L}$

*Calendula suffruticosa Vahl subsp. fulgida (Raf.) Guadagno

Carpesium cernuum L.

Centaurea aspera L. subsp. aspera

Centaurea babylonica (L.) L. 


$\begin{array}{ll}136 & \text { Asteraceae } \\ 137 & \text { Asteraceae } \\ 138 & \text { Asteraceae } \\ 139 & \text { Asteraceae } \\ 140 & \text { Asteraceae } \\ 141 & \text { Asteraceae } \\ 142 & \text { Asteraceae } \\ 143 & \text { Asteraceae } \\ 144 & \text { Asteraceae } \\ 145 & \text { Asteraceae } \\ 146 & \text { Asteraceae } \\ 147 & \text { Asteraceae } \\ 148 & \text { Asteraceae } \\ 149 & \text { Asteraceae } \\ 150 & \text { Asteraceae } \\ 151 & \text { Asteraceae } \\ 152 & \text { Asteraceae } \\ 153 & \text { Asteraceae } \\ 154 & \text { Asteraceae } \\ 155 & \text { Asteraceae } \\ 156 & \text { Asteraceae } \\ 157 & \text { Asteraceae } \\ 158 & \text { Asteraceae } \\ 159 & \text { Asteraceae } \\ 160 & \text { Asteraceae } \\ 161 & \text { Asteraceae } \\ 162 & \text { Asteraceae } \\ 163 & \text { Asteraceae } \\ 164 & \text { Asteraceae }\end{array}$

Centaurea cineraria $\mathrm{L}$. subsp. cineraria

Centaurea decipiens Thuill.

**Centaurea diluta Aiton

Centaurea jacea L. subsp. jacea

Centaurea jacea subsp. angustifolia $\mathrm{Gremli}$

Centaurea paniculata L. subsp. paniculata

Centaurea thuillieri (Dostál) J. Duvign. \& Lambinon

Cheirolophus intybaceus (Lam.) Dostál

Cichorium endivia $\mathrm{L}$.

****Cota tinctoria (L.) J. Gay

Cotula australis (Spreng.) Hooker f.

Cotula coronopifolia $\mathrm{L}$.

Crepis bursifolia $\mathrm{L}$.

Crepis nicaeensis Balb. ex Pers.

*Crepis sancta (L.) Babc. subsp. nemausensis (P. Fourn.) Babc.

Crepis vesicaria L. subsp. stellata (Ball) Babc.

Crepis vesicaria subsp. taraxacifolia (Thuill.) Thell.

**Cyanus segetum Hil

Cynara scolymus L.

Delairea odorata Lem.

Eclipta prostrata (L.) L.

Erigeron аппииs (L.) Pers.

Erigeron bonariensis $\mathrm{L}$

Erigeron canadensis $\mathrm{L}$.

Erigeron karvinskianus DC.

Erigeron philadelphicus $\mathrm{L}$

Erigeron sumatrensis Retz.

Eriocephalus africanus L.
1

Neo

$\mathrm{Neo}$

$\mathrm{NeO}$

Neo

$\mathrm{Neo}$

Arch

$\mathrm{Neo}$

$\mathrm{NeO}$

Arch

$\mathrm{Neo}$

$\mathrm{Neo}$

Neo

$\mathrm{Neo}$

Arch

$\mathrm{Neo}$

Arch

Arch

Arch

Da

Arch

Neo

$\mathrm{Neo}$

Neo

Neo

Neo

$\mathrm{Neo}$

$\mathrm{Da}$

\begin{tabular}{|c|c|c|}
\hline & Cas & Synanthropic \\
\hline & Nat & Wetlands \\
\hline \multirow[t]{9}{*}{ Inv } & & Synanthropic \\
\hline & Nat & Synanthropic \\
\hline & Cas & Synanthropic \\
\hline & Cas & Synanthropic \\
\hline & Nat & Synanthropic \\
\hline & Cas & Synanthropic \\
\hline & Cas & Agricultural \\
\hline & Cas & Synanthropic \\
\hline & Inv & Synanthropic \\
\hline \multirow[t]{3}{*}{ Inv } & Inv & Wetlands \\
\hline & Nat & Synanthropic \\
\hline & Cas & Synanthropic \\
\hline \multirow[t]{3}{*}{ Nat } & & Synanthropic \\
\hline & Nat & Synanthropic \\
\hline & Nat & Synanthropic \\
\hline Cas & & Agricultural \\
\hline Nat & & Agricultural \\
\hline Cas & & Synanthropic \\
\hline \multirow[t]{2}{*}{ Nat } & Nat & Wetlands \\
\hline & Cas & Wetlands \\
\hline Inv & Inv & Synanthropic \\
\hline \multirow[t]{3}{*}{ Inv } & Inv & Synanthropic \\
\hline & Cas & Synanthropic \\
\hline & Cas & Synanthropic \\
\hline Inv & Inv & Synanthropic \\
\hline Cas & & Synanthropic \\
\hline Nat & & Agricultural \\
\hline
\end{tabular}


Gaillardia $\times$ grandiflora Van Houtte Galinsoga parviflora Cav.

Gamochaeta antillana (Urban) Anderberg Gazania linearis (Thunb.) Druce Gazania rigens (L.) Gaertne

Geropogon hybridus L.

Glebionis coronaria (L.) Spach Grindelia robusta Nutt.

Guizotia abyssinica (L. fil.) Cass. Helianthus annuus $\mathrm{L}$.

Helianthus pauciflorus Nutt. subsp. pauciflorus Helianthus tuberosus $\mathrm{L}$.

Helianthus $\times$ laetiflorus Pers.

Helichrysum petiolare Hilliard \& B. L. Burtt

Helichrysum stoechas (L.) Moench

Helminthotheca echioides (L.) Holub

Hieracium glaucinum subsp. jaubertianum (Timb.-Lagr. \& Loret) O.

$$
\text { Bolòs \& Vigo }
$$

Hieracium mixtum Froe

Hieracium murorum $\mathrm{L}$

Lactuca sativa $\mathrm{L}$.

Leontodon hispidus $\mathrm{L}$.

Leucanthemum vulgare (Vaill.) Lam.

Mantisalca salmantica (L.) Briq. et Cavill.

Matricaria chamomilla $\mathrm{L}$.

Petasites pyrenaicus (L.) G. López

Picris hieracioides $\mathrm{L}$.

*****icris hieracioides L. subsp. hieracioides

Scolymus grandiflorus Desf.

Senecio angulatus $\mathrm{L}$. $\mathrm{f}$.
Neo

Neo

Neo

Da

Neo

$\mathrm{NeO}$

Neo

$\mathrm{NeO}$

$\mathrm{Neo}$

Neo

Arch

Da

Arch

Neo
$\mathrm{NeO}$

$\mathrm{Neo}$

$\mathrm{NeO}$

Neo

Arch

Cas

Inv

Cas

Cas

$\mathrm{Neo}$

Nat

Cas

Nat

Cas

Inv

Cas

Cas

Nat

Cas

Cas

Cas

Cas

Cas

Cas

Nat

Nat

Nat

Cas

Cas

Nat

Nat

Nat

Nat

Inv
Synanthropic

Agricultural

Coastal

Synanthropic

Synanthropic

Synanthropic

Agricultural

Coasta

Synanthropic

Agricultural

Agricultural

Riparian

Wetlands

Synanthropic

Synanthropic

Synanthropic

Woodlands

Coastal

Synanthropic

Agricultural

Agricultural

Synanthropic

Agricultural

Agricultural

Wetlands

Synanthropic

Agricultural

Synanthropic

Synanthropic 


\begin{tabular}{lc}
194 & Asteraceae \\
195 & Asteraceae \\
196 & Asteraceae \\
197 & Asteraceae \\
198 & Asteraceae \\
199 & Asteraceae \\
200 & Asteraceae \\
201 & Asteraceae \\
202 & Asteraceae \\
203 & Asteraceae \\
204 & Asteraceae \\
205 & Asteraceae \\
206 & Asteraceae \\
207 & Asteraceae \\
208 & Asteraceae \\
209 & Balsaminaceae \\
210 & Basellaceae \\
211 & Berberidaceae \\
212 & Betulaceae \\
213 & Betulaceae \\
214 & Betulaceae \\
215 & Bignoniaceae \\
216 & Bignoniaceae \\
217 & Bignoniaceae \\
218 & Bignoniaceae \\
219 & Bignoniaceae \\
220 & Boraginaceae \\
221 & Boraginaceae \\
222 & Brassicaceae \\
& \\
\hline
\end{tabular}

Senecio inaequidens DC.

Solidago canadensis $\mathrm{L}$.

Soliva sessilis Ruiz \& Pavon

Symphyotrichum squamatum (Spreng.) G.L. Nesom

Tagetes minuta $\mathrm{L}$.

Tanacetum balsamita $\mathrm{L}$

Tanacetum parthenium (L.) Sch. Bip.

Tanacetum vulgare $\mathrm{L}$.

Tolpis barbata (L.) Gaertn

Tragopogon porrifolius subsp. eriospermus (Ten.) Greuter

****Tragopogon pratensis $\mathrm{L}$. subsp. pratensis

*Tussilago farfara $\mathrm{L}$.

Xanthium orientale L. subsp. italicum (Moretti) Greuter

Xanthium spinosum $\mathrm{L}$.

**Zinnia elegans Jacq

Impatiens balfourii Hook. f. I. de Balfur

Anredera cordifolia (Ten.) Steenis

Mahonia aquifolium (Pursh) Nutt.

Alnus cordata (Loisel.) Duby

Alnus incana (L.) Moench

Corylus avellana $\mathrm{L}$.

Campsis radicans (L.) Seem.

Catalpa bignonioides Walter

Jacaranda mimosifolia D. Don.

Podranea ricasoliana (Tanfani) Sprague

Tecomaria capensis (Thunb.) Lindl.

Heliotropium curassavicum $\mathrm{L}$.

Phacelia tanacetifolia Benth.

Alyssum corsicum Duby

\begin{tabular}{|c|c|c|c|c|c|c|}
\hline \multirow[t]{3}{*}{1} & 1 & $\mathrm{Neo}$ & $\mathrm{Neo}$ & Nat & Inv & Riparian \\
\hline & 1 & & $\mathrm{Neo}$ & & Inv & Riparian \\
\hline & 1 & & $\mathrm{Neo}$ & & Cas & Synanthropic \\
\hline \multirow[t]{3}{*}{1} & 1 & $\mathrm{Neo}$ & $\mathrm{Neo}$ & Inv & Nat & Wetlands \\
\hline & 1 & & $\mathrm{Neo}$ & & Cas & Synanthropic \\
\hline & 1 & & Arch & & Cas & Synanthropic \\
\hline \multirow[t]{5}{*}{1} & 1 & Arch & Arch & Cas & Cas & Agricultural \\
\hline & 1 & & Arch & & Cas & Synanthropic \\
\hline & 1 & & Arch & & Cas & Synanthropic \\
\hline & 1 & & $\mathrm{Neo}$ & & Cas & Agricultural \\
\hline & 1 & & $\mathrm{Neo}$ & & Cas & Synanthropic \\
\hline 1 & & $\mathrm{Da}$ & & Nat & & Woodlands \\
\hline 1 & 1 & $\mathrm{Neo}$ & $\mathrm{Neo}$ & Nat & Inv & Synanthropic \\
\hline 1 & 1 & $\mathrm{Neo}$ & $\mathrm{Neo}$ & Inv & Inv & Agricultural \\
\hline 1 & & $\mathrm{Neo}$ & & Cas & & Synanthropic \\
\hline \multirow[t]{3}{*}{1} & 1 & $\mathrm{Neo}$ & $\mathrm{Neo}$ & Cas & Inv & Synanthropic \\
\hline & 1 & & $\mathrm{Neo}$ & & Cas & Synanthropic \\
\hline & 1 & & $\mathrm{Neo}$ & & Cas & Synanthropic \\
\hline 1 & & Arch & & Cas & & Riparian \\
\hline 1 & & Arch & & Cas & & Riparian \\
\hline 1 & & Arch & & Cas & & Riparian \\
\hline 1 & 1 & $\mathrm{Neo}$ & $\mathrm{Neo}$ & Cas & Cas & Synanthropic \\
\hline 1 & & $\mathrm{Neo}$ & & Cas & & Riparian \\
\hline \multirow[t]{2}{*}{1} & & $\mathrm{Neo}$ & & Cas & & Synanthropic \\
\hline & 1 & & $\mathrm{Neo}$ & & Cas & Synanthropic \\
\hline 1 & & $\mathrm{Neo}$ & & Cas & & Riparian \\
\hline 1 & & $\mathrm{Neo}$ & & Nat & & Synanthropic \\
\hline \multirow[t]{2}{*}{1} & 1 & $\mathrm{Neo}$ & $\mathrm{Neo}$ & Cas & Cas & Wetlands \\
\hline & 1 & & Arch & & Nat & Wetlands \\
\hline
\end{tabular}


Armoracia rusticana P. Gaertn., B. Mey. \& Scherb.

Brassica nigra (L.) W.D.J. Koch

Brassica oleracea $\mathrm{L}$.

Brassica procumbens (Poir.) O.E. Schulz

$$
\text { *****Brassica rapa L. s.l. }
$$

Brassica rapa L. subsp. campestris (L.) Clapham Brassica rapa L. subsp. rapa

Camelina alyssum (Mill.) Thell. subsp. alyssum Camelina microcarpa DC.

Camelina sativa (L.) Crantz subsp. sativa

**Cardamine flexuosa With subsp. debilis O.E. Schulz

Cardamine pratensis $\mathrm{L}$.

Carrichtera апnиа $(\mathrm{L}.) \mathrm{DC}$

Diplotaxis catholica (L.) DC. subsp. catholica

Diplotaxis erucoides (L.) DC. subsp. erucoides

Diplotaxis muralis (L.) DC.

Erysimum cheiri (L.) Crantz

Hesperis matronalis L. subsp. matronalis

Isatis tinctoria L. subsp. tinctoria

Lepidium campestre (L.) R. Br.

Lepidium coronopus (L.) Al-Shehbaz

$$
\text { Lepidium didymum } \mathrm{L} \text {. }
$$

Lepidium heterophyllum Benth.

Lepidium latifolium $\mathrm{L}$.

Lepidium ruderale $\mathrm{L}$.

Lepidium sativum L. subsp. sativum

Lepidium virginicum $\mathrm{L}$. Brassica napus $\mathrm{L}$.

Arch
Arch
Arch
Arch

Arch
Neo

Arch
Arch
Arch
Da
Da
Neo

Arch

Da

Da

Neo

Da

Arch

Arch

Arch

Arch

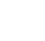

$\mathrm{Neo}$

Neo

Arch

Arch

Arch

Arch

Arch

Arch

Arch

(n)
Neo

Cas

Cas

Nat

Nat

Cas

Cas

(1)

$\mathrm{Na}$

Cas

Cas

Cas

Cas

Cas

\section{Synanthropic}

Synanthropic

Agricultural

Agricultural

Agricultural

Synanthropic

Synanthropic

Agricultural

Agricultural

Agricultural

Synanthropic

Woodlands

Synanthropic

Synanthropic

Synanthropic

Agricultural

Synanthropic

Synanthropic

Agricultural

Agricultural

Synanthropic

Wetlands

Synanthropic

Wetlands

Synanthropic

Agricultural

Wetlands

Riparian 


\begin{tabular}{ll}
252 & Brassicaceae \\
253 & Brassicaceae \\
254 & Brassicaceae \\
255 & Brassicaceae \\
256 & Brassicaceae \\
257 & Brassicaceae \\
258 & Brassicaceae \\
259 & Brassicaceae \\
260 & Brassicaceae \\
261 & Brassicaceae \\
262 & Brassicaceae \\
263 & Cactaceae \\
264 & Cactaceae \\
265 & Cactaceae \\
266 & Cactaceae \\
267 & Cactaceae \\
268 & Cactaceae \\
269 & Cactaceae \\
270 & Cactaceae \\
271 & Cactaceae \\
272 & Cactaceae \\
273 & Cactaceae \\
274 & Cactaceae \\
275 & Cactaceae \\
276 & Cactaceae \\
277 & Campanulaceae \\
278 & Campanulaceae \\
279 & Campanulaceae \\
280 & Campanulaceae \\
& \\
\hline 25
\end{tabular}

Malcolmia maritima (L.) R. Br.

Malcolmia triloba (L.) Spreng.

Matthiola incana (L.) R. Br. subsp. incana

Moricandia arvensis (L.) DC.

Neslia paniculata (L.) Desv. subsp. thracica (Velen.) Bornm.

Raphanus sativus $\mathrm{L}$.

Rorippa austriaca (Crantz) Besser

Rorippa palustris (L.) Besser

Sinapis alba L. subsp. alba

Sisymbrium orientale $\mathrm{L}$. subsp. orientale

Sisymbrium runcinatum DC.

Austrocylindropuntia cylindrica (Lam.) Backeb. Austrocylindropuntia subulata (Mühlenpf.) Backeb.

**Hylocereus undatus (Haworth) Britton \& Rose

Nopalea dejecta Salm-Dick

*Opuntia amyclaea Ten.

Opuntia decumbens Salm-Dyck

Opuntia dillenii (Ker Gawl.) Haw.

Opuntia ficus-indica (L.) Mill.

Opuntia humifusa (Raf.) Raf.

*Opuntia microdasys (Lehm.) Pfeiff. subsp. microdasys

Opuntia monacantha (Willd.) Haw.

Opuntia stricta (Haw.) Haw.

Opuntia tomentosa Salm-Dyck

Opuntia tuna (L.) Mill.

Campanula patula $\mathrm{L}$.

Campanula rapunculoides $\mathrm{L}$. subsp. rapunculoides

Campanula versicolor Andrews

\begin{tabular}{|c|c|c|c|c|c|c|}
\hline 1 & D & Arch & Arch & Cas & Cas & Coastal \\
\hline & 1 & & $\mathrm{Neo}$ & & Cas & Coastal \\
\hline 1 & & Arch & & Nat & & Synanthropic \\
\hline 1 & & $\mathrm{Da}$ & & & & Agricultural \\
\hline 1 & & Arch & & Nat & & Agricultural \\
\hline 1 & & Arch & & Cas & & Agricultural \\
\hline & 1 & & Neo & & Cas & Wetlands \\
\hline & 1 & & $\mathrm{Da}$ & & Nat & Wetlands \\
\hline 1 & & Arch & & Nat & & Agricultural \\
\hline 1 & & Arch & & Nat & & Agricultural \\
\hline & D & & $\mathrm{Neo}$ & & Cas & Synanthropic \\
\hline 1 & & $\mathrm{Neo}$ & & Cas & & Matorrals \\
\hline 1 & 1 & Neo & $\mathrm{Neo}$ & Inv & Nat & Matorrals \\
\hline 1 & & Neo & & Cas & & Riparian \\
\hline 1 & & Neo & & Cas & & Synanthropic \\
\hline 1 & & $\mathrm{Neo}$ & & Nat & & Matorrals \\
\hline 1 & & Neo & & Cas & & Coastal \\
\hline 1 & 1 & $\mathrm{Neo}$ & $\mathrm{NeO}$ & Nat & Cas & Synanthropic \\
\hline 1 & 1 & Neo & $\mathrm{NeO}$ & Inv & Inv & Matorrals \\
\hline 1 & & $\mathrm{Neo}$ & & Nat & & Matorrals \\
\hline 1 & & Neo & & Cas & & Synanthropic \\
\hline 1 & 1 & Neo & $\mathrm{NeO}$ & Cas & Inv & Synanthropic \\
\hline 1 & & Neo & & Cas & & Matorrals \\
\hline 1 & & Neo & & Cas & & Matorrals \\
\hline 1 & & $\mathrm{Neo}$ & & Nat & & Matorrals \\
\hline & 1 & & $\mathrm{NeO}$ & & Cas & Synanthropic \\
\hline 1 & & Neo & & Cas & & Synanthropic \\
\hline 1 & & Neo & & Cas & & Synanthropic \\
\hline & 1 & & Arch & & Cas & Synanthropic \\
\hline
\end{tabular}




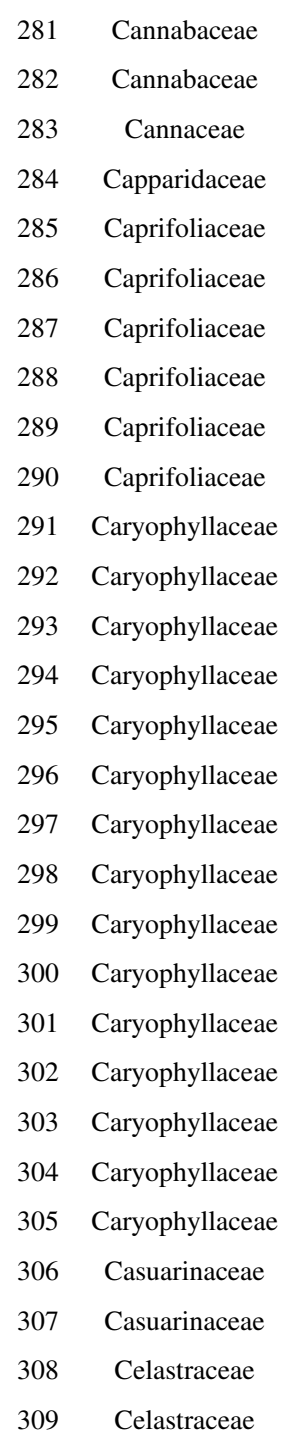

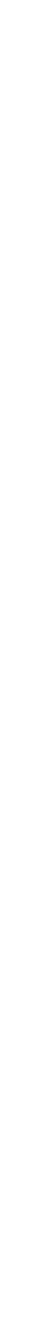

Cannabis sativa $\mathrm{L}$.

Celtis australis $\mathrm{L}$.

Canna indica $\mathrm{L}$.

**Capparis spinosa $\mathrm{L}$.

Centranthus ruber (L.) DC. subsp. ruber

Fedia graciliflora Fisch. \& C. A. Mey.

Knautia integrifolia (L.) Bertol. subsp. integrifolia

Lonicera japonica Thunb.

Sixalix atropurpurea (L.) Greuter \& Burdet subsp. atropurpurea

Valeriana officinalis $\mathrm{L}$.

****Agrostemma githago $\mathrm{L}$

Cerastium comatum Desv.

Cerastium tomentosum $\mathrm{L}$.

Gypsophila muralis L.

Saponaria ocymoides L. subsp. ocimoides

Silene conica $\mathrm{L}$.

Silene coronaria (L.) Clairv.

Silene cretica $\mathrm{L}$.

Silene disticha Willd.

***Silene fuscata Brot.

Silene italica (L.) Pers. subsp. italica

Silene pendula $\mathrm{L}$.

Silene portensis $\mathrm{L}$.

Stellaria graminea $\mathrm{L}$.

Vaccaria hispanica (Mill.) Rauschert

Allocasuarina verticillata L.A.S. Johnson

Casuarina cunninghamiana Miq.

Euonymus japonicus L. f.

Parnassia palustris L. subsp. palustris

Arch
$\mathrm{Da}$
$\mathrm{Neo}$
Arch
Arch
$\mathrm{Da}$
$\mathrm{Neo}$
$\mathrm{Da}$
$\mathrm{Da}$

Arch
$\mathrm{Da}$
$\mathrm{Neo}$
Arch
$\mathrm{NeO}$
Arch

Cas

Nat

Nat

Cas

Cas

Neo

Arch

$\mathrm{Neo}$

Da

Neo

$\mathrm{Neo}$

$\mathrm{Neo}$

$\mathrm{Neo}$

$\mathrm{Neo}$

Neo

Arch

\section{Inv}

Agricultural

Synanthropic

Wetlands

Synanthropic

Synanthropic

Synanthropic

Coastal

Synanthropic

Riparian

Synanthropic

Cas

Nat

Agricultural

Matorrals

Matorrals

Synanthropic

Synanthropic

Coastal

Synanthropic

Synanthropic

Synanthropic

Synanthropic

Synanthropic

Synanthropic

Coastal

Synanthropic

Agricultural

Synanthropic

Synanthropic

Synanthropic 


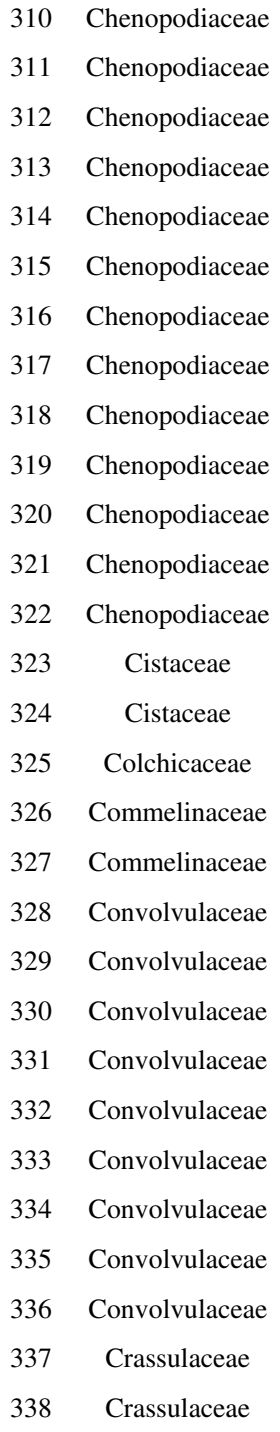

$$
\text { Atriplex halimus } \mathrm{L} \text {. }
$$

Atriplex tatarica L. subsp. tatarica

Bassia scoparia (L.) A.J. Scott

Beta trigyna Waldst. et Kit.

Beta vulgaris $\mathrm{L}$. subsp. vulgaris

Chenopodium giganteum D. Don

Chenopodium hircinum Schrad

Chenopodium hybridum $\mathrm{L}$.

Dysphania ambrosioides (L.) Mosyakin \& Clemants

Dysphania multifida (L.) Mosyakin \& Clemants

**Dysphania pumilio (R. Br.) Mosyakin \& Clemants

$$
\text { Polycnemum majus A. Braun }
$$

Spinacia oleracea $\mathrm{L}$.

$$
\text { Cistus albidus } \mathrm{L} \text {. }
$$

Cistus laurifolius L. subsp. atlanticus (Pit.) Sennen \& Mauricio

$$
\begin{aligned}
& \text { Colchicum variegatum } \mathrm{L} \text {. } \\
& \text { Commelina communis } \mathrm{L} \text {. }
\end{aligned}
$$

Tradescantia fluminensis Velloso

Calystegia silvatica (Kit.) Griseb.

Convolvulus tricolor $\mathrm{L}$. subsp. tricolor

Convolvulus tricolor subsp. cupanianus (Tod.) Cavara \& Grande

$$
\text { Cuscuta campestris Yunck. }
$$

Cuscuta epilinum Weihe

Dichondra micrantha Urb.

Ipomoea cairica (L.) Sweet

Ipomoea indica (Burm.) Merr.

Ipomoea purpurea (L.) Roth

Aeonium arboreum (L.) Webb. et Berthel.

Aeonium decorum Webb ex Bolle

\section{Neo}

Arch

Neo

Arch

1

1

D

1

1

1

1
Arch

Cas

Nat

Nat

Arch

Neo

$\mathrm{NeO}$

$\mathrm{NeO}$

$\mathrm{NeO}$

$\mathrm{Neo}$

$\mathrm{Neo}$

Arch

Da

Neo

Arch

$\mathrm{Neo}$

$\mathrm{NeO}$

Arch

Da

Neo

Nat
Nat

Nat

Cas
Cas

$\mathrm{Neo}$

$\mathrm{Neo}$
Nat

Nat

Synanthropic

Coastal

Coastal

Agricultural

Agricultural

Synanthropic

Synanthropic

Synanthropic

Riparian

Wetlands

Synanthropic

Coastal

Agricultural

Synanthropic

Woodlands

Coastal

Wetlands

Wetlands

Woodlands

Synanthropic

Agricultural

Agricultural

Agricultural

Synanthropic

Synanthropic

Riparian

Inv Synanthropic

Coastal

Coastal 
**Aeonium haworthii (Webb \& Berthel.) Webb \& Berthel.

Cotyledon oblonga Haw.

Cotyledon orbiculata $\mathrm{L}$.

Crassula muscosa $\mathrm{L}$

Crassula ovata Druce

Hylotelephium maximum (L.) Holub subsp. maximum

Kalanchoë daigremontiana Hamet et H. Perrier

*Kalanchoe delagoensis Eckl. \& Zeyh.

Kalanchö̈ $\times$ houghtonii D.B. Ward

Sedum acre L.

Sedum mexicanum Britton

Sedum multiceps Coss. \& Durieu

*Sedum palmeri $\mathrm{S}$. Watson

**Sedum praealtum $\mathrm{DC}$.

Sedum sediforme (Jacq.) Pau

Sempervivum tectorum $\mathrm{L}$.

Citrullus colocynthis (L.) Schrad.

Citrullus lanatus (Thunb.) Matsum. et Nakai

$$
\text { Cucumis melo } \mathrm{L} \text {. }
$$

Cucumis sativus $\mathrm{L}$

Cucurbita maxima Duchesne

$$
\text { Cucurbita pepo } \mathrm{L}
$$

Lagenaria siceraria (Molina) Standl.

Sechium edule Swartz

Callitropsis arizonica (Greene) D.P. Little

Callitropsis macrocarpa (Hartw.) D.P. Little

Calocedrus decurrens (Torr.) Florin

Chamaecyparis lawsoniana (Murray) Parl.

Cupressus sempervirens $\mathrm{L}$.

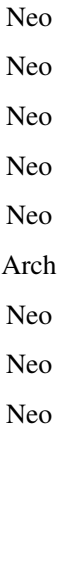

Neo

Neo

Arch

Arch

Arch

Arch

Neo

Neo

Arch

Neo

Neo

Neo

Neo

Neo

\begin{tabular}{|c|c|c|c|}
\hline \multirow[t]{3}{*}{$\mathrm{Neo}$} & Cas & Cas & Synanthropic \\
\hline & Nat & & Synanthropic \\
\hline & Cas & & Coastal \\
\hline \multirow[t]{2}{*}{$\mathrm{Neo}$} & Cas & Cas & Coastal \\
\hline & Cas & & Coastal \\
\hline \multirow[t]{2}{*}{ Arch } & Cas & Nat & Synanthropic \\
\hline & Cas & & Matorrals \\
\hline \multirow[t]{2}{*}{$\mathrm{Neo}$} & Cas & Cas & Synanthropic \\
\hline & Cas & & Synanthropic \\
\hline $\mathrm{Neo}$ & & Nat & Synanthropic \\
\hline $\mathrm{Neo}$ & & Cas & Coastal \\
\hline \multirow[t]{3}{*}{$\mathrm{Neo}$} & & Nat & Synanthropic \\
\hline & Cas & & Synanthropic \\
\hline & Cas & & Synanthropic \\
\hline Arch & & Nat & Synanthropic \\
\hline Arch & Cas & Cas & Synanthropic \\
\hline Arch & & Cas & Synanthropic \\
\hline Arch & Cas & Cas & Synanthropic \\
\hline Arch & Cas & Cas & Agricultural \\
\hline \multirow[t]{3}{*}{ Arch } & Cas & Cas & Agricultural \\
\hline & Cas & & Agricultural \\
\hline & Cas & & Agricultural \\
\hline \multirow[t]{7}{*}{ Arch } & Cas & Cas & Agricultural \\
\hline & Cas & & Agricultural \\
\hline & Cas & & Woodlands \\
\hline & Cas & & Woodlands \\
\hline & Cas & & Woodlands \\
\hline & Cas & & Woodlands \\
\hline & Cas & & Woodlands \\
\hline
\end{tabular}

Arch 


$\begin{array}{lc}368 & \text { Cupressaceae } \\ 369 & \text { Cupressaceae } \\ 370 & \text { Cyperaceae } \\ 371 & \text { Cyperaceae } \\ 372 & \text { Cyperaceae } \\ 373 & \text { Cyperaceae } \\ 374 & \text { Cyperaceae } \\ 375 & \text { Cyperaceae } \\ 376 & \text { Didiereaceae } \\ 377 & \text { Ebenaceae } \\ 378 & \text { Elaeagnaceae } \\ 379 & \text { Elatinaceae } \\ 380 & \text { Ericaceae } \\ 381 & \text { Ericaceae } \\ 382 & \text { Euphorbiaceae } \\ 383 & \text { Euphorbiaceae } \\ 384 & \text { Euphorbiaceae } \\ 385 & \text { Euphorbiaceae } \\ 386 & \text { Euphorbiaceae } \\ 387 & \text { Euphorbiaceae } \\ 388 & \text { Euphorbiaceae } \\ 389 & \text { Euphorbiaceae } \\ 390 & \text { Euphorbiaceae } \\ 391 & \text { Euphorbiaceae } \\ 392 & \text { Fabaceae } \\ 393 & \text { Fabaceae } \\ 394 & \text { Fabaceae } \\ 395 & \text { Fabaceae } \\ 396 & \text { Fabaceae }\end{array}$

Juniperus chinensis $\mathrm{L}$.

Thuja orientalis L.

***Bolboschoenus laticarpus Marhold, Hroudová, Zákravský \&

$$
\text { Ducháček }
$$

Cyperus alternifolius L. subsp. flabelliformis (Rottb.) Kük

Cyperus difformis $\mathrm{L}$.

Cyperus eragrostis Lam. non Vahl.

Cyperus michelianus (L.) Delile

Cyperus rotundus $\mathrm{L}$.

Portulacaria afra Jacq.

Diospyros lotus $\mathrm{L}$.

Elaeagnus angustifolia $\mathrm{L}$.

Elatine triandra Schkuhr

Calluna vulgaris (L.) Hull

Orthilia secunda (L.) House

Euphorbia cyparissias $\mathrm{L}$.

Euphorbia esula L. subsp. saratoi (Ard.) P. Fourn.

$$
\text { Euphorbia hirta L. }
$$

Euphorbia humifusa Willd.

Euphorbia lathyris $\mathrm{L}$.

Euphorbia maculata L.

Euphorbia prostrata Aiton

Euphorbia serpens Kunth

**Euphorbia serpens Kunth var. serpens

$$
\text { Ricinus communis } \mathrm{L} \text {. }
$$

Acacia baileyana F. Muell.

Acacia caven (Molina) Molina

Acacia cultriformis Cunn.

Acacia dealbata Link.

****Acacia longifolia (Andrews) Willd.
Neo

$\mathrm{Neo}$

$\mathrm{Neo}$

Neo

$\mathrm{NeO}$

$\mathrm{Neo}$

Arch

$\mathrm{Da}$

$\mathrm{Neo}$

Neo

$\mathrm{NeO}$

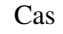

Neo

Da

$\mathrm{Neo}$

$\mathrm{Neo}$

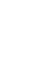

$\mathrm{Neo}$

$\mathrm{Neo}$

Neo

Da

$\mathrm{NeO}$

$\mathrm{Neo}$

$\mathrm{Neo}$

Nat

Nat

Neo

$\mathrm{Neo}$

Inv

Cas

Nat

Neo

$\mathrm{NeO}$

$\mathrm{Neo}$

Inv

Cas

Nat

$\mathrm{Neo}$

$\mathrm{Neo}$
Synanthropic

Synanthropic

Wetlands

Wetlands

Wetlands

Wetlands

Wetlands

Synanthropic

Synanthropic

Synanthropic

Wetlands

Wetlands

Woodlands

Woodlands

Synanthropic

Synanthropic

Agricultural

Synanthropic

Synanthropic

Synanthropic

Inv Synanthropic

Synanthropic

Inv Synanthropic

Inv Wetlands

Cas Riparian

Riparian

Woodlands

Inv

Woodlands

Cas Cas Woodlands 


\begin{tabular}{ll}
397 & Fabaceae \\
398 & Fabaceae \\
399 & Fabaceae \\
400 & Fabaceae \\
401 & Fabaceae \\
402 & Fabaceae \\
403 & Fabaceae \\
404 & Fabaceae \\
405 & Fabaceae \\
406 & Fabaceae \\
407 & Fabaceae \\
408 & Fabaceae \\
409 & Fabaceae \\
410 & Fabaceae \\
411 & Fabaceae \\
412 & Fabaceae \\
413 & Fabaceae \\
414 & Fabaceae \\
415 & Fabaceae \\
416 & Fabaceae \\
417 & Fabaceae \\
418 & Fabaceae \\
419 & Fabaceae \\
420 & Fabaceae \\
421 & Fabaceae \\
422 & Fabaceae \\
423 & Fabaceae \\
424 & Fabaceae \\
425 & Fabaceae \\
\hline 4
\end{tabular}

\begin{abstract}
Acacia mearnsii De Willd.
Acacia melanoxylon R. Br.

Acacia pycnantha Benth.

****Acacia retinodes Schltdl.
\end{abstract}

Acacia saligna (Labill.) H. L. Wendl.

****Albizia julibrissin Durazz.

Amorpha fruticosa $\mathrm{L}$.

Anthyllis vulneraria subsp. carpatica (Pant.) Nyman

Caesalpinia tinctoria Domb. ex DC.

Ceratonia siliqua $\mathrm{L}$.

Cercis siliquastrum $\mathrm{L}$.

Cicer arietinum $\mathrm{L}$

Coronilla valentina subsp. glauca (L.) Batt

Cytisus multiflorus (L'Hér.) Sweet

Cytisus scoparius (L.) Link subsp. scoparius

Cytisus striatus (Hill) Rothm.

Erythrostemon gilliesii (Wall. ex Hook.) Klotzsch

Galega officinalis L.

Genista aetnensis (Biv.) DC.

Genista ephedroides DC.

***Genista januensis subsp. lydia (Boiss.) Kit Tan \& Zielinski

Genista linifolia L.

Genista tinctoria L.

Gleditsia triacanthos $\mathrm{L}$.

Glycyrrhiza glabra L.

Haematoxylum campechianum $\mathrm{L}$.

Laburnum anagyroides Medik.

Lathyrus odoratus $\mathrm{L}$.

Lathyrus sativus L.

\begin{tabular}{|c|c|c|}
\hline 1 & 1 & $\mathrm{Neo}$ \\
\hline 1 & & $\mathrm{Neo}$ \\
\hline 1 & & $\mathrm{Neo}$ \\
\hline 1 & 1 & $\mathrm{Neo}$ \\
\hline 1 & 1 & $\mathrm{Neo}$ \\
\hline 1 & 1 & $\mathrm{Neo}$ \\
\hline \multirow[t]{2}{*}{1} & & $\mathrm{Neo}$ \\
\hline & 1 & \\
\hline 1 & & $\mathrm{Neo}$ \\
\hline 1 & 1 & $\mathrm{Da}$ \\
\hline 1 & 1 & Arch \\
\hline \multirow[t]{3}{*}{1} & 1 & Arch \\
\hline & 1 & \\
\hline & 1 & \\
\hline \multirow[t]{2}{*}{1} & & $\mathrm{Da}$ \\
\hline & 1 & \\
\hline 1 & & $\mathrm{Neo}$ \\
\hline \multirow[t]{4}{*}{1} & 1 & Arch \\
\hline & 1 & \\
\hline & 1 & \\
\hline & 1 & \\
\hline \multirow[t]{2}{*}{1} & 1 & $\mathrm{Da}$ \\
\hline & $\mathrm{D}$ & \\
\hline 1 & 1 & $\mathrm{Neo}$ \\
\hline 1 & & Arch \\
\hline \multirow[t]{2}{*}{ D } & & $\mathrm{Neo}$ \\
\hline & 1 & \\
\hline 1 & & $\mathrm{Neo}$ \\
\hline 1 & 1 & Arch \\
\hline
\end{tabular}

\begin{tabular}{|c|c|c|c|}
\hline \multirow[t]{3}{*}{ Neo } & Inv & Nat & Riparian \\
\hline & Cas & & Woodlands \\
\hline & Nat & & Woodlands \\
\hline $\mathrm{Neo}$ & Inv & Inv & Coastal \\
\hline $\mathrm{Neo}$ & Inv & Nat & Coastal \\
\hline \multirow[t]{2}{*}{$\mathrm{Neo}$} & Cas & Cas & Synanthropic \\
\hline & Nat & & Wetlands \\
\hline \multirow[t]{2}{*}{$\mathrm{Neo}$} & & Cas & Synanthropic \\
\hline & Cas & & Synanthropic \\
\hline Arch & Nat & Nat & Matorrals \\
\hline Arch & Cas & Nat & Woodlands \\
\hline Arch & Cas & Cas & Agricultural \\
\hline $\mathrm{Neo}$ & & Cas & Matorrals \\
\hline $\mathrm{Neo}$ & & Cas & Matorrals \\
\hline & Nat & & Matorrals \\
\hline \multirow[t]{2}{*}{$\mathrm{NeO}$} & & Inv & Matorrals \\
\hline & Cas & & Synanthropic \\
\hline Arch & Cas & Cas & Riparian \\
\hline $\mathrm{Da}$ & & Nat & Matorrals \\
\hline $\mathrm{NeO}$ & & Nat & Matorrals \\
\hline $\mathrm{NeO}$ & & Cas & Synanthropic \\
\hline $\mathrm{Da}$ & Nat & Nat & Matorrals \\
\hline $\mathrm{NeO}$ & & Cas & Coastal \\
\hline \multirow[t]{3}{*}{$\mathrm{NeO}$} & Cas & Cas & Matorrals \\
\hline & Nat & & Agricultural \\
\hline & Cas & & Agricultural \\
\hline \multirow[t]{2}{*}{$\mathrm{NeO}$} & & Cas & Woodlands \\
\hline & Cas & & Synanthropic \\
\hline Arch & Cas & Nat & Synanthropic \\
\hline
\end{tabular}




$\begin{array}{ll}426 & \text { Fabaceae } \\ 427 & \text { Fabaceae } \\ 428 & \text { Fabaceae } \\ 429 & \text { Fabaceae } \\ 430 & \text { Fabaceae } \\ 431 & \text { Fabaceae } \\ 432 & \text { Fabaceae } \\ 433 & \text { Fabaceae } \\ 434 & \text { Fabaceae } \\ 435 & \text { Fabaceae } \\ 436 & \text { Fabaceae } \\ 437 & \text { Fabaceae } \\ 438 & \text { Fabaceae } \\ 439 & \text { Fabaceae } \\ 440 & \text { Fabaceae } \\ 441 & \text { Fabaceae } \\ 442 & \text { Fabaceae } \\ 443 & \text { Fabaceae } \\ 444 & \text { Fabaceae } \\ 445 & \text { Fabaceae } \\ 446 & \text { Fabaceae } \\ 447 & \text { Fabaceae } \\ 448 & \text { Fabaceae } \\ 449 & \text { Fabaceae } \\ 450 & \text { Fabaceae } \\ 451 & \text { Fabaceae } \\ 452 & \text { Fabaceae } \\ 453 & \text { Fabaceae } \\ 454 & \text { Fabaceae }\end{array}$

Lathyrus tingitanus $\mathrm{L}$.

Lens culinaris Medik.

Lupinus albus L. subsp. albus

Lupinus luteus $\mathrm{L}$.

Lupinus pilosus $\mathrm{L}$.

Medicago arborea $\mathrm{L}$

Medicago falcata $\mathrm{L}$.

Medicago laciniata (L.) Mill. subsp. laciniata

Medicago rugosa Desr.

Medicago sativa $\mathrm{L}$.

Medicago soleirolii Duby

**Medicago $\times$ varia Martyn

Melilotus albus Medik.

Melilotus officinalis Lam.

Melilotus siculus (Turra) B.D. Jacks.

Onobrychis viciifolia Scop.

Ononis spinosa L. subsp. spinosa

Paraserianthes lophantha (Willd.) I.C. Nielsen

Parkinsonia aculeata $\mathrm{L}$

Phaseolus vulgaris $\mathrm{L}$.

Pisum sativum L. subsp. biflorum (Raf.) Soldano

Pisum sativum L. subsp. sativum

Retama monosperma (L.) Boiss.

Robinia pseudoacacia $\mathrm{L}$.

Securigera varia $(\mathrm{L}$.$) Lassen$

Senegalia visco (Lorentz ex Griseb.) Seigler et Ebinger

**Senna corymbosa (Lam.) H.S. Irwin \& Barneby

Sesbania punicea (Cav.) Benth.

Spartium junceum $\mathrm{L}$.

Arch

Arch

Arch

Arch

Arch

Arch

Da

Arch

Neo

$\mathrm{Neo}$

Neo

Arch

Arch

$\mathrm{NeO}$

Neo

Neo

Neo

Da

\begin{tabular}{|c|c|c|c|}
\hline Arch & & Cas & Matorrals \\
\hline Arch & Cas & Cas & Synanthropic \\
\hline Arch & Cas & Nat & Agricultural \\
\hline $\mathrm{Da}$ & & Nat & Agricultural \\
\hline Arch & & Nat & Synanthropic \\
\hline $\mathrm{Neo}$ & Nat & Inv & Coastal \\
\hline Arch & & Cas & Synanthropic \\
\hline $\mathrm{Da}$ & & Nat & Synanthropic \\
\hline $\mathrm{Da}$ & & Nat & Synanthropic \\
\hline \multirow[t]{3}{*}{ Arch } & Nat & Nat & Agricultural \\
\hline & Cas & & Synanthropic \\
\hline & Cas & & Synanthropic \\
\hline $\mathrm{Neo}$ & & Nat & Synanthropic \\
\hline \multirow[t]{2}{*}{ Arch } & & Cas & Synanthropic \\
\hline & Inv & & Synanthropic \\
\hline Arch & Cas & Cas & Synanthropic \\
\hline $\mathrm{Neo}$ & & Cas & Synanthropic \\
\hline \multirow[t]{2}{*}{$\mathrm{Neo}$} & Nat & Inv & Wetlands \\
\hline & Nat & & Woodlands \\
\hline \multirow[t]{2}{*}{$\mathrm{Neo}$} & Cas & Cas & Agricultural \\
\hline & Nat & & Synanthropic \\
\hline Arch & Cas & Cas & Agricultural \\
\hline $\mathrm{Neo}$ & Cas & Cas & Synanthropic \\
\hline $\mathrm{Neo}$ & Nat & Inv & Synanthropic \\
\hline \multirow[t]{3}{*}{ Arch } & & Cas & Synanthropic \\
\hline & Nat & & Riparian \\
\hline & Cas & & Synanthropic \\
\hline $\mathrm{Neo}$ & Nat & Inv & Synanthropic \\
\hline $\mathrm{Da}$ & Nat & Nat & Matorrals \\
\hline
\end{tabular}




$\begin{array}{lc}455 & \text { Fabaceae } \\ 456 & \text { Fabaceae } \\ 457 & \text { Fabaceae } \\ 458 & \text { Fabaceae } \\ 459 & \text { Fabaceae } \\ 460 & \text { Fabaceae } \\ 461 & \text { Fabaceae } \\ 462 & \text { Fabaceae } \\ 463 & \text { Fabaceae } \\ 464 & \text { Fabaceae } \\ 465 & \text { Fabaceae } \\ 466 & \text { Fagaceae } \\ 467 & \text { Fagaceae } \\ 468 & \text { Fagaceae } \\ 469 & \text { Garryaceae } \\ 470 & \text { Geraniaceae } \\ 471 & \text { Geraniaceae } \\ 472 & \text { Geraniaceae } \\ 473 & \text { Geraniaceae } \\ 474 & \text { Geraniaceae } \\ 475 & \text { Grossulariaceae } \\ 476 & \text { Haloragaceae } \\ 477 & \text { Hydrocharitaceae } \\ 478 & \text { Hydrocharitaceae } \\ 479 & \text { Hypericaceae } \\ 480 & \text { Hypericaceae } \\ 481 & \text { Iridaceae } \\ 482 & \text { Iridaceae } \\ 483 & \text { Iridaceae }\end{array}$

Sulla coronaria $($ L.) Medik.

Trifolium alexandrinum $\mathrm{L}$.

Trifolium incarnatum L. subsp. incarnatum

Trifolium pratense L. subsp. sativum Schreb.

Trigonella foenum-graecum $\mathrm{L}$.

****Ulex europaeus $\mathrm{L}$

****Vachellia farnesiana $($ L.) Wight \& Arn.

Vachellia karroo (Hayne) Banfi \& Galasso Vicia faba $\mathrm{L}$.

Vicia sativa L. subsp. sativa

****Wisteria sinensis (Sims) Sweet

Castanea sativa Mill.

Fagus sylvatica L. subsp. sylvatica

Quercus robur L. subsp. robur

*Aucuba japonica Thunb.

**Geranium sanguineum $\mathrm{L}$.

Pelargonium capitatum (L.) L'Her. ex Ait.

Pelargonium graveolens L'Hér.

**Pelargonium $\times$ hortorum L.H. Bailey

Pelargonium zonale (L.) Aiton

Ribes rubrum $\mathrm{L}$.

Myriophyllum aquaticum (Vell.) Verdc.

Elodea canadensis Michx

Najas graminea Delile var. graminea

Hypericum androsaemum $\mathrm{L}$.

Hypericum calycinum $\mathrm{L}$.

Chasmanthe bicolor (Gasp. ex Vis.) N.E.Br.

Chasmanthe aethiopica (L.) N.E.Br.

* Chasmanthe floribunda (Salisb.) N.E.Br.

Arch
Arch
Arch
Arch
Neo
Neo
Arch
Arch
Neo
Arch
Arch
Arch
Neo
Neo
Neo

eo

$\mathrm{Neo}$

Neo

$\mathrm{NeO}$

Neo
Arch

Arch

Neo

$\mathrm{NeO}$

Neo

Arch

Neo

(as

Neo

Neo

$\mathrm{Neo}$

Neo

Da

eo

$\mathrm{N}$
$\mathrm{N}$
$\mathrm{N}$
$\mathrm{C}$
$\mathrm{N}$
$\mathrm{N}$
$\mathrm{N}$
$\mathrm{N}$
$\mathrm{N}$
$\mathrm{N}$
$\mathrm{C}$
$\mathrm{C}$
$\mathrm{C}$
$\mathrm{C}$
$\mathrm{C}$
$\mathrm{C}$

Nat
Nat
Nat
Cas
Nat
Nat
Nat
Nat
Nat
Nat
Cas
Cas
Cas
Cas
Cas
Cas
Cas

Cas

Cas

Neo

Neo

Inv

Cas
Nat Agricultural

Agricultural

Agricultural

Cas Agricultural

Agricultural

Matorrals

Woodlands

Coastal

Agricultural

Agricultural

Cas Synanthropic

Woodlands

Woodlands

Woodlands

Synanthropic

Synanthropic

Synanthropic

Cas Synanthropic

Synanthropic

Coastal

Cas Synanthropic

Inv Wetlands

Inv Wetlands

Cas Wetlands

Synanthropic

Synanthropic

Cas Synanthropic

Synanthropic 


$\begin{array}{ll}484 & \text { Iridaceae } \\ 485 & \text { Iridaceae } \\ 486 & \text { Iridaceae } \\ 487 & \text { Iridaceae } \\ 488 & \text { Iridaceae } \\ 489 & \text { Iridaceae } \\ 490 & \text { Iridaceae } \\ 491 & \text { Iridaceae } \\ 492 & \text { Juglandaceae } \\ 493 & \text { Juglandaceae } \\ 494 & \text { Lamiaceae } \\ 495 & \text { Lamiaceae } \\ 496 & \text { Lamiaceae } \\ 497 & \text { Lamiaceae } \\ 498 & \text { Lamiaceae } \\ 499 & \text { Lamiaceae } \\ 500 & \text { Lamiaceae } \\ 501 & \text { Lamiaceae } \\ 502 & \text { Lamiaceae } \\ 503 & \text { Lamiaceae } \\ 504 & \text { Lamiaceae } \\ 505 & \text { Lamiaceae } \\ 506 & \text { Lamiaceae } \\ 507 & \text { Lamiaceae } \\ 508 & \text { Lamiaceae } \\ 509 & \text { Lamiaceae } \\ 510 & \text { Lamiaceae } \\ 511 & \text { Lamiaceae } \\ 512 & \text { Lamiaceae } \\ & \end{array}$

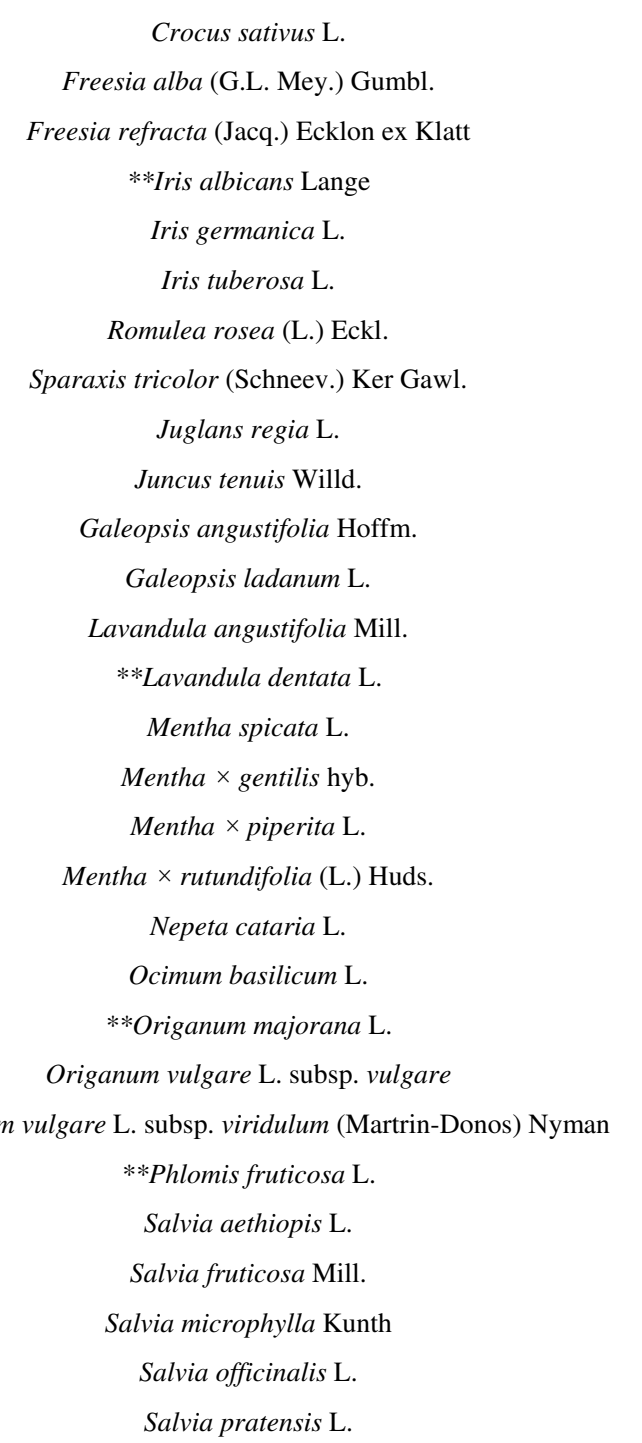

\begin{tabular}{|c|c|c|}
\hline \multirow[t]{2}{*}{1} & $\mathrm{D}$ & Arch \\
\hline & 1 & \\
\hline 1 & & $\mathrm{Neo}$ \\
\hline 1 & 1 & $\mathrm{Neo}$ \\
\hline 1 & 1 & Arch \\
\hline 1 & & $\mathrm{Da}$ \\
\hline D & & $\mathrm{Neo}$ \\
\hline 1 & & $\mathrm{Neo}$ \\
\hline \multirow[t]{5}{*}{1} & 1 & $\mathrm{Da}$ \\
\hline & 1 & \\
\hline & 1 & \\
\hline & $\mathrm{D}$ & \\
\hline & 1 & \\
\hline 1 & & $\mathrm{Neo}$ \\
\hline \multirow[t]{2}{*}{1} & 1 & Arch \\
\hline & 1 & \\
\hline \multirow[t]{2}{*}{1} & 1 & Arch \\
\hline & 1 & \\
\hline 1 & & $\mathrm{Da}$ \\
\hline 1 & 1 & Arch \\
\hline 1 & 1 & $\mathrm{Neo}$ \\
\hline 1 & & Arch \\
\hline 1 & & Arch \\
\hline D & & Arch \\
\hline \multirow[t]{3}{*}{1} & & $\mathrm{Da}$ \\
\hline & 1 & \\
\hline & 1 & \\
\hline \multirow[t]{2}{*}{1} & 1 & Arch \\
\hline & D & \\
\hline
\end{tabular}

\begin{tabular}{|c|c|c|c|}
\hline Arch & Cas & Cas & Agricultural \\
\hline \multirow[t]{2}{*}{$\mathrm{Neo}$} & & Inv & Matorrals \\
\hline & Cas & & Synanthropic \\
\hline $\mathrm{Neo}$ & Cas & Nat & Synanthropic \\
\hline \multirow[t]{4}{*}{ Arch } & Nat & Nat & Synanthropic \\
\hline & & & Synanthropic \\
\hline & & & Synanthropic \\
\hline & Cas & & Wetlands \\
\hline Arch & Nat & Nat & Riparian \\
\hline $\mathrm{Neo}$ & & Cas & Wetlands \\
\hline Arch & & Cas & Matorrals \\
\hline Arch & & Cas & Matorrals \\
\hline \multirow[t]{2}{*}{ Arch } & & Cas & Synanthropic \\
\hline & Cas & & Synanthropic \\
\hline Arch & Nat & Cas & Riparian \\
\hline $\mathrm{Neo}$ & & Cas & Riparian \\
\hline Arch & Cas & Cas & Riparian \\
\hline \multirow[t]{2}{*}{$\mathrm{Neo}$} & & Cas & Agricultural \\
\hline & Nat & & Riparian \\
\hline Arch & Cas & Cas & Agricultural \\
\hline \multirow[t]{4}{*}{ Arch } & Nat & Cas & Agricultural \\
\hline & Cas & & Agricultural \\
\hline & Cas & & Synanthropic \\
\hline & Cas & & Synanthropic \\
\hline Arch & & Cas & Synanthropic \\
\hline $\mathrm{Neo}$ & & Cas & Riparian \\
\hline Arch & Cas & Cas & Agricultural \\
\hline $\mathrm{Da}$ & & Cas & Synanthropic \\
\hline
\end{tabular}




$\begin{array}{ll}513 & \text { Lamiaceae } \\ 514 & \text { Lamiaceae } \\ 515 & \text { Lamiaceae } \\ 516 & \text { Lamiaceae } \\ 517 & \text { Lauraceae } \\ 518 & \text { Liliaceae } \\ 519 & \text { Liliaceae } \\ 520 & \text { Liliaceae } \\ 521 & \text { Liliaceae } \\ 522 & \text { Linaceae } \\ 523 & \text { Linaceae } \\ 524 & \text { Lomariopsidaceae } \\ 525 & \text { Lythraceae } \\ 526 & \text { Lythraceae } \\ 527 & \text { Lythraceae } \\ 528 & \text { Malvaceae } \\ 529 & \text { Malvaceae } \\ 530 & \text { Malvaceae } \\ 531 & \text { Malvaceae } \\ 532 & \text { Malvaceae } \\ 533 & \text { Malvaceae } \\ 534 & \text { Malvaceae } \\ 535 & \text { Malvaceae } \\ 536 & \text { Malvaceae } \\ 537 & \text { Malvaceae } \\ 538 & \text { Malvaceae } \\ 539 & \text { Malvaceae } \\ 540 & \text { Malvaceae } \\ 541 & \text { Malvaceae } \\ & \end{array}$

Salvia tiliifolia Vahl

**Satureja hortensis L

Teucrium fruticans L. subsp. fruticans

Thymus vulgaris $\mathrm{L}$. subsp. vulgaris

Laurus nobilis $\mathrm{L}$.

Lilium candidum $\mathrm{L}$.

Tulipa agenensis DC.

Tulipa gesneriana $\mathrm{L}$.

Tulipa raddii Reboul

Linum narbonense $\mathrm{L}$.

Linum usitatissimum $\mathrm{L}$

Nephrolepis exaltata (L.) Schott

Ammannia auriculata Willd.

Ammannia verticillata (Ard.) Lam.

Punica granatum $\mathrm{L}$.

Abutilon theophrasti Medik.

**Alcea biennis Winterl

Alcea rosea $\mathrm{L}$.

Hibiscus rosa-sinensis $\mathrm{L}$.

Hibiscus syriacus $\mathrm{L}$.

Hibiscus trionum $\mathrm{L}$.

Lagunaria patersonia (Andrews) G. Don

Malope malacoides $\mathrm{L}$.

Malva moschata $\mathrm{L}$.

Malva trimestris (L.) Salisb.

Modiola caroliniana (L.) G. Don

Tilia platyphyllos Scop. s.1.

Tilia tomentosa Moench

Tilia $\times$ vulgaris Hayne

\begin{tabular}{|c|c|c|}
\hline & 1 & \\
\hline 1 & 1 & Neo \\
\hline \multirow[t]{2}{*}{1} & & Arch \\
\hline & 1 & \\
\hline 1 & & $\mathrm{Da}$ \\
\hline 1 & 1 & Arch \\
\hline D & D & $\mathrm{Neo}$ \\
\hline \multirow[t]{3}{*}{ D } & & Arch \\
\hline & D & \\
\hline & D & \\
\hline 1 & D & Arch \\
\hline 1 & & $\mathrm{Neo}$ \\
\hline 1 & & $\mathrm{Neo}$ \\
\hline 1 & & $\mathrm{Neo}$ \\
\hline 1 & 1 & Arch \\
\hline 1 & 1 & $\mathrm{Neo}$ \\
\hline 1 & & $\mathrm{Neo}$ \\
\hline 1 & 1 & Arch \\
\hline 1 & & $\mathrm{Neo}$ \\
\hline 1 & 1 & $\mathrm{Neo}$ \\
\hline 1 & & $\mathrm{Neo}$ \\
\hline \multirow[t]{5}{*}{1} & & $\mathrm{Neo}$ \\
\hline & $\mathrm{D}$ & \\
\hline & 1 & \\
\hline & 1 & \\
\hline & 1 & \\
\hline \multirow[t]{2}{*}{1} & 1 & Arch \\
\hline & 1 & \\
\hline 1 & & Arch \\
\hline
\end{tabular}

\begin{tabular}{|c|c|c|c|}
\hline $\mathrm{Neo}$ & & Cas & Agricultural \\
\hline \multirow[t]{2}{*}{$\mathrm{Neo}$} & Cas & Cas & Agricultural \\
\hline & Nat & & Matorrals \\
\hline \multirow[t]{2}{*}{$\mathrm{Neo}$} & & Cas & Synanthropic \\
\hline & Inv & & Woodlands \\
\hline Arch & Nat & Cas & Synanthropic \\
\hline \multirow[t]{2}{*}{$\mathrm{Neo}$} & & Cas & Agricultural \\
\hline & & & Synanthropic \\
\hline Arch & & Cas & Agricultural \\
\hline $\mathrm{Da}$ & & Cas & Synanthropic \\
\hline \multirow[t]{4}{*}{ Arch } & Nat & Cas & Agricultural \\
\hline & Cas & & Riparian \\
\hline & Nat & & Wetlands \\
\hline & Nat & & Wetlands \\
\hline Arch & Nat & Cas & Agricultural \\
\hline \multirow[t]{2}{*}{$\mathrm{Neo}$} & Nat & Nat & Agricultural \\
\hline & Cas & & Synanthropic \\
\hline \multirow[t]{2}{*}{$\mathrm{Neo}$} & Nat & Cas & Synanthropic \\
\hline & Cas & & Synanthropic \\
\hline \multirow[t]{3}{*}{$\mathrm{Neo}$} & Cas & Cas & Synanthropic \\
\hline & Nat & & Wetlands \\
\hline & Cas & & Coastal \\
\hline Arch & & Cas & Agricultural \\
\hline Arch & & Cas & Synanthropic \\
\hline $\mathrm{Da}$ & & Cas & Synanthropic \\
\hline $\mathrm{Neo}$ & & Nat & Wetlands \\
\hline Arch & Cas & Cas & Riparian \\
\hline Arch & & Cas & Riparian \\
\hline & Cas & & Riparian \\
\hline
\end{tabular}




$\begin{array}{lc}542 & \text { Martyniaceae } \\ 543 & \text { Meliaceae } \\ 544 & \text { Molluginaceae } \\ 545 & \text { Molluginaceae } \\ 546 & \text { Montiaceae } \\ 547 & \text { Moraceae } \\ 548 & \text { Moraceae } \\ 549 & \text { Moraceae } \\ 550 & \text { Moraceae } \\ 551 & \text { Moraceae } \\ 552 & \text { Moraceae } \\ 553 & \text { Moraceae } \\ 554 & \text { Moraceae } \\ 555 & \text { Moraceae } \\ 556 & \text { Moraceae } \\ 557 & \text { Myrtaceae } \\ 558 & \text { Myrtaceae } \\ 559 & \text { Myrtaceae } \\ 560 & \text { Myrtaceae } \\ 561 & \text { Myrtaceae } \\ 562 & \text { Myrtaceae } \\ 563 & \text { Myrtaceae } \\ 564 & \text { Myrtaceae } \\ 565 & \text { Nyctaginaceae } \\ 566 & \text { Nyctaginaceae } \\ 567 & \text { Nymphaeaceae } \\ 568 & \text { Nymphaeaceae } \\ 569 & \text { Nymphaeaceae } \\ 570 & \text { Oleaceae } \\ & \\ 550\end{array}$

*Proboscidea louisianica (Mill.) Thell.

$$
\text { Melia azedarach } \mathrm{L} \text {. }
$$$$
\text { Glinus lotoides L. }
$$

Mollugo cerviana (L.) Ser.

Claytonia perfoliata Willd.

Broussonetia papyrifera (L.) Vent.

Fatoua villosa (Thunb.) Nakai

$$
\text { Ficus carica L. }
$$

Ficus elastica Roxb.

**Ficus microcarpa L.f.

$$
\text { Ficus retusa } \mathrm{L} \text {. }
$$

Maclura pomifera (Rafin.) C.K. Schneider

$$
\text { Morus alba } \mathrm{L} \text {. }
$$

***Morus kagayamae Koidz.

Morus nigra $\mathrm{L}$.

Eucalyptus botryoides $\mathrm{Sm}$

Eucalyptus camaldulensis Dehnh.

Eucalyptus globulus Labill.

Eucalyptus gomphocephala D.C.

$$
\text { Eucalyptus robusta } \mathrm{Sm}
$$

Eucalyptus rudis Endl.

Eucalyptus sideroxylon A. Cunn. ex Wools

$$
\text { Eucalyptus tereticornis Sm. }
$$

Bougainvillea spectabilis Willd.

$$
\text { Mirabilis jalapa } \mathrm{L}
$$

$$
\text { **Nuphar lutea (L.) Sm. }
$$

Nymphaea flava Leitner ex Audubon

$$
\text { Nymphaea mexicana Zucc. }
$$

Fraxinus excelsior L. subsp. excelsior

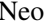

$\mathrm{Neo}$

Neo

Arch

Neo

Da

$\mathrm{Da}$

Neo

Neo

$\mathrm{NeO}$

Arch

Arch

Neo

$\mathrm{NeO}$

Neo

Neo

$\mathrm{Neo}$

\begin{tabular}{|c|c|c|}
\hline Cas & & Synanthropic \\
\hline Cas & Cas & Synanthropic \\
\hline Inv & Nat & Wetlands \\
\hline & & Wetlands \\
\hline & Nat & Riparian \\
\hline Cas & Cas & Synanthropic \\
\hline & Cas & Agricultural \\
\hline Nat & & Woodlands \\
\hline Cas & & Synanthropic \\
\hline Cas & & Synanthropic \\
\hline Cas & & Synanthropic \\
\hline Cas & & Synanthropic \\
\hline Cas & Cas & Riparian \\
\hline & Cas & Synanthropic \\
\hline Cas & Cas & Agricultural \\
\hline Cas & & Woodlands \\
\hline Inv & Nat & Riparian \\
\hline Nat & Nat & Riparian \\
\hline Cas & & Woodlands \\
\hline Cas & & Woodlands \\
\hline Cas & & Woodlands \\
\hline Cas & & Woodlands \\
\hline Cas & & Woodlands \\
\hline Cas & & Synanthropic \\
\hline Inv & Inv & Synanthropic \\
\hline & & Wetlands \\
\hline Cas & & Wetlands \\
\hline Nat & & Wetlands \\
\hline Cas & & Riparian \\
\hline
\end{tabular}

Neo

Neo

Neo

$\mathrm{Neo}$

$\mathrm{Da}$

Neo

$\mathrm{Neo}$

Arch 


\begin{tabular}{ll}
571 & Oleaceae \\
572 & Oleaceae \\
573 & Oleaceae \\
574 & Oleaceae \\
575 & Oleaceae \\
576 & Onagraceae \\
577 & Onagraceae \\
578 & Onagraceae \\
579 & Onagraceae \\
580 & Onagraceae \\
581 & Onagraceae \\
582 & Onagraceae \\
583 & Orobanchaceae \\
584 & Orobanchaceae \\
585 & Oxalidaceae \\
586 & Oxalidaceae \\
587 & Oxalidaceae \\
588 & Oxalidaceae \\
589 & Oxalidaceae \\
590 & Oxalidaceae \\
591 & Oxalidaceae \\
592 & Oxalidaceae \\
593 & Oxalidaceae \\
594 & Oxalidaceae \\
595 & Oxalidaceae \\
596 & Oxalidaceae \\
597 & Papaveraceae \\
598 & Papaveraceae \\
599 & Papaveraceae \\
\hline 5
\end{tabular}

Jasminum officinale L.

*****igustrum lucidum W.T. Aiton

$$
\text { Ligustrum vulgare } \mathrm{L} \text {. }
$$

Olea europaea L.

Syringa vulgaris $\mathrm{L}$.

Ludwigia peploides subsp. montevidensis (Spreng.) P.H. Raven

$$
\text { Oenothera biennis L. }
$$

Oenothera glazioviana Micheli

Oenothera lindheimeri (Engelm \& A. Gray) W.L. Wagner \& Hoch.

$$
\text { ***Oenothera rosea L'Hér. ex Aiton }
$$

Oenothera sinuosa W.L.Wagner \& Hoch

$$
\text { Oenothera stricta Link }
$$

Rhinanthus alectorolophus (Scop.) Pollich

$$
\text { Rhinanthus minor } \mathrm{L} \text {. }
$$

Oxalis articulata Savigny

**Oxalis bowiei Lindl.

Oxalis carnosa Molina

Oxalis corniculata $\mathrm{L}$.

**Oxalis debilis Kunth

*Oxalis dillenii Jacq.

**Oxalis latifolia Kunth

Oxalis pes-caprae $\mathrm{L}$.

Oxalis purpurata Jacq.

Oxalis purpurea L. non Thunb.

$$
\text { Oxalis stricta } \mathrm{L} \text {. }
$$

Oxalis violacea $\mathrm{L}$. non Thunb.

Eschscholzia californica Cham.

$$
\text { Fumaria agraria Lag. }
$$

Fumaria kralikii Jord.

Arch
Arch
Da
Arch

Neo
Neo

Neo
Neo
Neo

Neo
Neo
Neo
Da
Neo
Neo
Neo
Neo
Neo
Neo
Neo
Neo
Da
Arch

Arch

$$
\begin{aligned}
& \text { Arch } \\
& \text { Neo } \\
& \\
& \\
& \text { Neo } \\
& \text { Neo } \\
& \text { Neo } \\
& \text { Neo } \\
& \text { Neo } \\
& \\
& \text { Neo } \\
& \text { Neo } \\
& \text { Neo } \\
& \text { Neo } \\
& \text { Neo } \\
& \\
& \text { Neo } \\
& \text { Neo } \\
& \text { Neo } \\
& \text { Neo } \\
&
\end{aligned}
$$

Cas

Cas

Synanthropic
Inv

Cas

Inv

Cas

Synanthropic

Synanthropic

Matorrals

Synanthropic

Inv Wetlands

Nat Riparian

Cas

Cas

Cas

Cas

Synanthropic

Synanthropic

Riparian

Wetlands

Agricultural

Synanthropic

Synanthropic

Synanthropic

Synanthropic

Synanthropic

Synanthropic

Synanthropic

Synanthropic

Cas Agricultural

Inv Synanthropic

Synanthropic

Cas Synanthropic

Cas Synanthropic

Synanthropic

Cas Synanthropic

Agricultural

Agricultural 


\begin{tabular}{|c|c|}
\hline 50 & Papaveraceae \\
\hline 601 & Papaveraceae \\
\hline 602 & Papaveraceae \\
\hline 503 & Papaveraceae \\
\hline 604 & Papaveraceae \\
\hline 605 & Papaveraceae \\
\hline 606 & Papaveraceae \\
\hline 607 & Papaveraceae \\
\hline 608 & Passifloraceae \\
\hline 609 & Paulowniaceae \\
\hline 610 & Phyllanthaceae \\
\hline 611 & Phytolaccaceae \\
\hline 612 & Phytolaccaceae \\
\hline 613 & Pinaceae \\
\hline 614 & Pinaceae \\
\hline 615 & Pinaceae \\
\hline 616 & Pinaceae \\
\hline 617 & Pinaceae \\
\hline 618 & Pinaceae \\
\hline 619 & Pinaceae \\
\hline 620 & Pinaceae \\
\hline 621 & Pinaceae \\
\hline 622 & Pinaceae \\
\hline 623 & Pinaceae \\
\hline 624 & Pinaceae \\
\hline 625 & Pinaceae \\
\hline 626 & Pinaceae \\
\hline 02 & Pittosporaceae \\
\hline 628 & Pittosporaceae \\
\hline
\end{tabular}

Papaver argemone L. subsp. argemone Papaver dubium L. subsp. dubium Papaver hybridum L.

Papaver lecoqii Lamotte

Papaver rhoeas L. subsp. rhoeas

Papaver setigerum DC

Papaver somniferum $\mathrm{L}$

Platycapnos spicatus (L.) Bernh. Passiflora caerulea $\mathrm{L}$

Paulownia tomentosa (Thunb.) Steud.

Phyllanthus tenellus Roxb.

Phytolacca americana $\mathrm{L}$.

Phytolacca dioica $\mathrm{L}$.

$$
\text { Abies alba Mill. }
$$

***Abies pinsapo Boiss.

Cedrus atlantica (Endl.) Carrière

*Cedrus deodara (Roxb. ex Lamb.) G.Don

Picea abies (L.) H. Karst.

Pinus brutia Ten.

Pinus canariensis C. Sm.

Pinus halepensis Mill.

Pinus nigra J.F. Arnold subsp. laricio (Poiret) Maire

Pinus pinaster Aiton subsp. pinaster

$$
\text { Pinus pinea } \mathrm{L} \text {. }
$$

Pinus radiata D. Don

Pinus sylvestris $\mathrm{L}$

Pseudotsuga menziesii (Mirb.) Franco

Pittosporum tobira (Thunb.) W.T. Aiton

Pittosporum undulatum Vent.

Da
Da
Da
Arch
Da
Da
Arch
Da
Neo
Neo

Neo
Neo
Arch
Neo
Neo
Neo
Neo
Da
Arch
Arch
Neo
arch
Neo
Neo
Neo

Neo$$
\operatorname{Arc}
$$

Neo

$\mathrm{Da}$

Arch

Arch

Arch

Neo

Arch

$\mathrm{Neo}$

Neo
Nat

Nat

Nat

Cas

Inv

Nat

Nat

Cas

Cas

Cas

$\mathrm{Neo}$

Neo

$\mathrm{Neo}$

Neo

$\mathrm{Neo}$

Arch

Agricultural

Agricultural

Agricultural

Agricultural

Agricultural

Synanthropic

Synanthropic

Agricultural

Synanthropic

Agricultural

Agricultural

Synanthropic

Synanthropic

Synanthropic

Synanthropic

Woodlands

Woodlands

Woodlands

Woodlands

Woodlands

Neo

Inv Woodlands

Woodlands

Woodlands

Arch

$\mathrm{Na}$

Nat

Coastal

Woodlands

Woodlands

$\mathrm{Neo}$

Woodlands

$\mathrm{Neo}$
Cas

Coastal 


\begin{tabular}{lc}
629 & Plantaginaceae \\
630 & Plantaginaceae \\
631 & Plantaginaceae \\
632 & Plantaginaceae \\
633 & Plantaginaceae \\
634 & Plantaginaceae \\
635 & Plantaginaceae \\
636 & Plantaginaceae \\
637 & Plantaginaceae \\
638 & Plantaginaceae \\
639 & Plantaginaceae \\
640 & Plantaginaceae \\
641 & Plantaginaceae \\
642 & Plantaginaceae \\
643 & Platanaceae \\
644 & Plumbaginaceae \\
645 & Plumbaginaceae \\
646 & Poaceae \\
647 & Poaceae \\
648 & Poaceae \\
649 & Poaceae \\
650 & Poaceae \\
651 & Poaceae \\
652 & Poaceae \\
653 & Poaceae \\
654 & Poaceae \\
655 & Poaceae \\
656 & Poaceae \\
657 & Poaceae \\
& \\
\hline 6
\end{tabular}

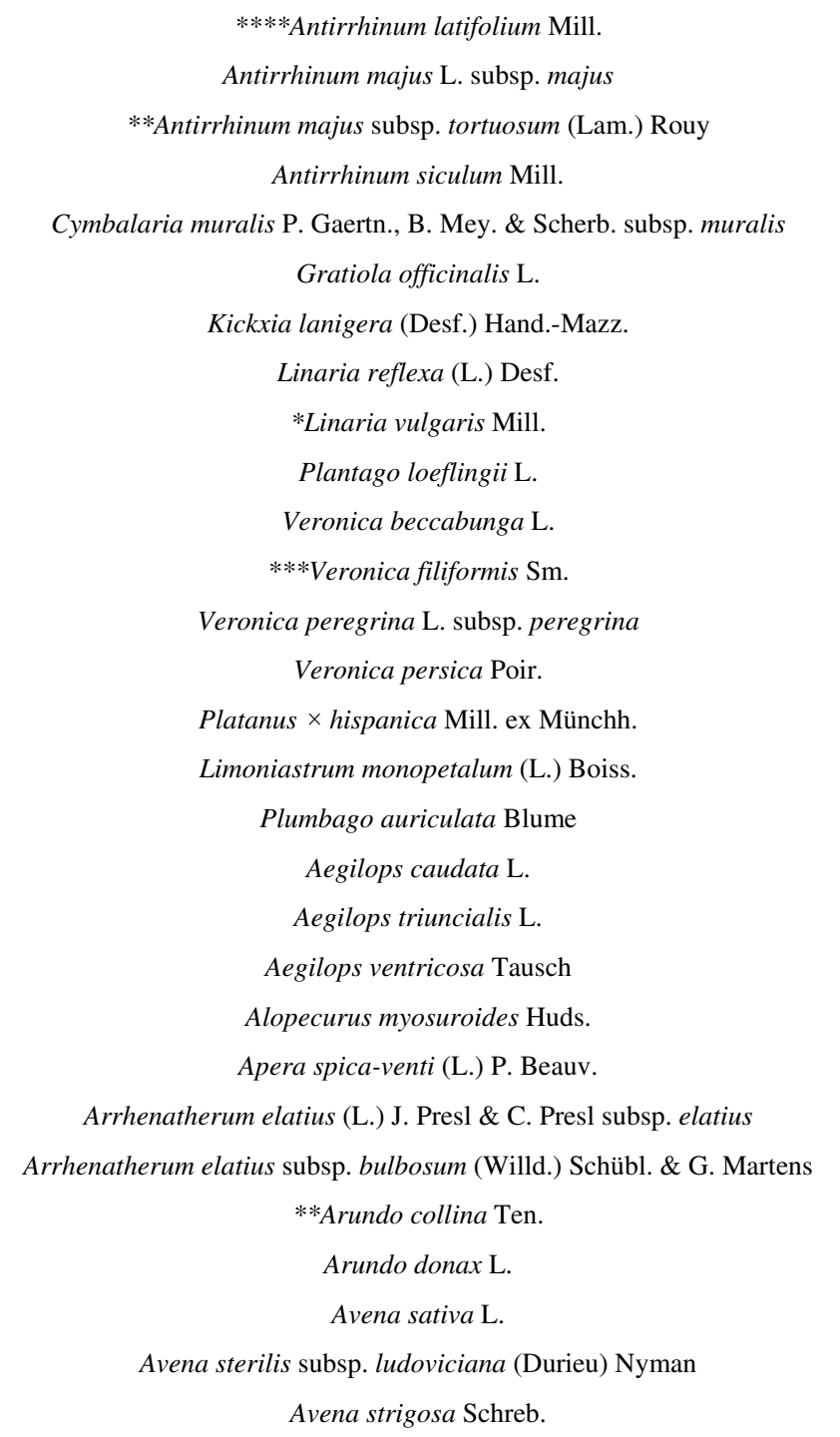

\begin{tabular}{|c|c|c|c|c|c|c|}
\hline & 1 & & $\mathrm{Neo}$ & & Nat & Synanthropic \\
\hline 1 & 1 & Arch & $\mathrm{Neo}$ & Nat & Nat & Synanthropic \\
\hline 1 & & $\mathrm{Da}$ & & Nat & & \\
\hline 1 & & $\mathrm{Da}$ & & Cas & & Synanthropic \\
\hline \multirow[t]{4}{*}{1} & 1 & $\mathrm{Da}$ & $\mathrm{Neo}$ & Nat & Inv & Synanthropic \\
\hline & 1 & & Arch & & Cas & Riparian \\
\hline & 1 & & $\mathrm{Da}$ & & Cas & Coastal \\
\hline & 1 & & Arch & & Cas & Synanthropic \\
\hline 1 & 1 & $\mathrm{Da}$ & $\mathrm{Da}$ & Nat & Inv & Synanthropic \\
\hline \multirow[t]{3}{*}{1} & & $\mathrm{Da}$ & & Cas & & \\
\hline & 1 & & Arch & & Nat & Wetlands \\
\hline & 1 & & $\mathrm{Neo}$ & & Nat & Synanthropic \\
\hline $\mathrm{D}$ & & Neo & & & & \\
\hline 1 & 1 & Arch & Arch & Nat & Nat & Agricultural \\
\hline \multirow[t]{2}{*}{1} & 1 & Neo & $\mathrm{Neo}$ & Cas & Nat & Synanthropic \\
\hline & 1 & & Arch & & Cas & Coastal \\
\hline 1 & & Neo & & Nat & & Synanthropic \\
\hline \multirow[t]{7}{*}{ D } & & Arch & & Cas & & Agricultural \\
\hline & 1 & & $\mathrm{Da}$ & & & Synanthropic \\
\hline & $\mathrm{D}$ & & Arch & & Cas & Synanthropic \\
\hline & 1 & & Arch & & Nat & Agricultural \\
\hline & $\mathrm{D}$ & & $\mathrm{Da}$ & & Cas & Synanthropic \\
\hline & 1 & & $\mathrm{Da}$ & & Nat & Synanthropic \\
\hline & 1 & & $\mathrm{Da}$ & & Nat & Synanthropic \\
\hline 1 & & $\mathrm{Neo}$ & & Cas & & Synanthropic \\
\hline 1 & 1 & Arch & Arch & Inv & Inv & Wetlands \\
\hline \multirow[t]{3}{*}{1} & 1 & Arch & Arch & Nat & Cas & Agricultural \\
\hline & 1 & & $\mathrm{Da}$ & & & Synanthropic \\
\hline & D & & Arch & & Cas & Synanthropic \\
\hline
\end{tabular}




$\begin{array}{ll}658 & \text { Poaceae } \\ 659 & \text { Poaceae } \\ 660 & \text { Poaceae } \\ 661 & \text { Poaceae } \\ 662 & \text { Poaceae } \\ 663 & \text { Poaceae } \\ 664 & \text { Poaceae } \\ 665 & \text { Poaceae } \\ 666 & \text { Poaceae } \\ 667 & \text { Poaceae } \\ 668 & \text { Poaceae } \\ 669 & \text { Poaceae } \\ 670 & \text { Poaceae } \\ 671 & \text { Poaceae } \\ 672 & \text { Poaceae } \\ 673 & \text { Poaceae } \\ 674 & \text { Poaceae } \\ 675 & \text { Poaceae } \\ 676 & \text { Poaceae } \\ 677 & \text { Poaceae } \\ 678 & \text { Poaceae } \\ 679 & \text { Poaceae } \\ 680 & \text { Poaceae } \\ 681 & \text { Poaceae } \\ 682 & \text { Poaceae } \\ 683 & \text { Poaceae } \\ 684 & \text { Poaceae } \\ 685 & \text { Poaceae } \\ 686 & \text { Poaceae }\end{array}$

Bothriochloa barbinodis (Lag.) Herter Briza media L.

Bromus alopecuros Poir. subsp. alopecuros Bromus alopecuros subsp. caroli-henrici (Greuter) P.M. Sm.

$$
\text { Bromus catharticus Vahl }
$$

Bromus erectus Huds. subsp. erectus

Bromus erectus subsp. longiflorus (Willd.) Arcang.

$$
\text { Bromus inermis Leyss. }
$$

Bromus secalinus L. subsp. secalinus

Cenchrus clandestinus (Hochst. ex Chiov.) Morrone

$$
\text { Cenchrus longisetus M. C. Johnst. }
$$

Cenchrus longispinus (Hack.) Fernald

Cenchrus setaceus (Forssk.) Morrone

**Ceratochloa cathartica (Vahl) Herter Chloris gayana Kunth

Cortaderia selloana (Schult.) Asch. et Graebn.

$$
\text { Crypsis aculeata (L.) Aiton }
$$

Crypsis schoenoides (L.) Lam.

****Cynosurus echinatus L. var. giganteus Salis

\section{Dactyloctenium aegyptium (L.) Richt.}

***Digitaria ciliaris (Retz.) Koeler

***Digitaria violascens Link

$$
\text { Echinochloa colona (L.) Link }
$$

Echinochloa crus-galli (L.) P. Beauv. subsp. Crusgalli **Echinochloa crus-galli (L.) Beauv. var. praticola Ohwi

$$
\text { Echinochloa oryzicola (Vasinger) Vasinger }
$$

Echinochloa oryzoides (Ard.) Fritsch.

$$
\text { Ehrharta erecta Lam. }
$$

Eleusine indica (L.) Gaertn. subsp. indica 


$\begin{array}{ll}687 & \text { Poaceae } \\ 688 & \text { Poaceae } \\ 689 & \text { Poaceae } \\ 690 & \text { Poaceae } \\ 691 & \text { Poaceae } \\ 692 & \text { Poaceae } \\ 693 & \text { Poaceae } \\ 694 & \text { Poaceae } \\ 695 & \text { Poaceae } \\ 696 & \text { Poaceae } \\ 697 & \text { Poaceae } \\ 698 & \text { Poaceae } \\ 699 & \text { Poaceae } \\ 700 & \text { Poaceae } \\ 701 & \text { Poaceae } \\ 702 & \text { Poaceae } \\ 703 & \text { Poaceae } \\ 704 & \text { Poaceae } \\ 705 & \text { Poaceae } \\ 706 & \text { Poaceae } \\ 707 & \text { Poaceae } \\ 708 & \text { Poaceae } \\ 709 & \text { Poaceae } \\ 710 & \text { Poaceae } \\ 711 & \text { Poaceae } \\ 712 & \text { Poaceae } \\ 713 & \text { Poaceae } \\ 714 & \text { Poaceae } \\ 715 & \text { Poaceae }\end{array}$

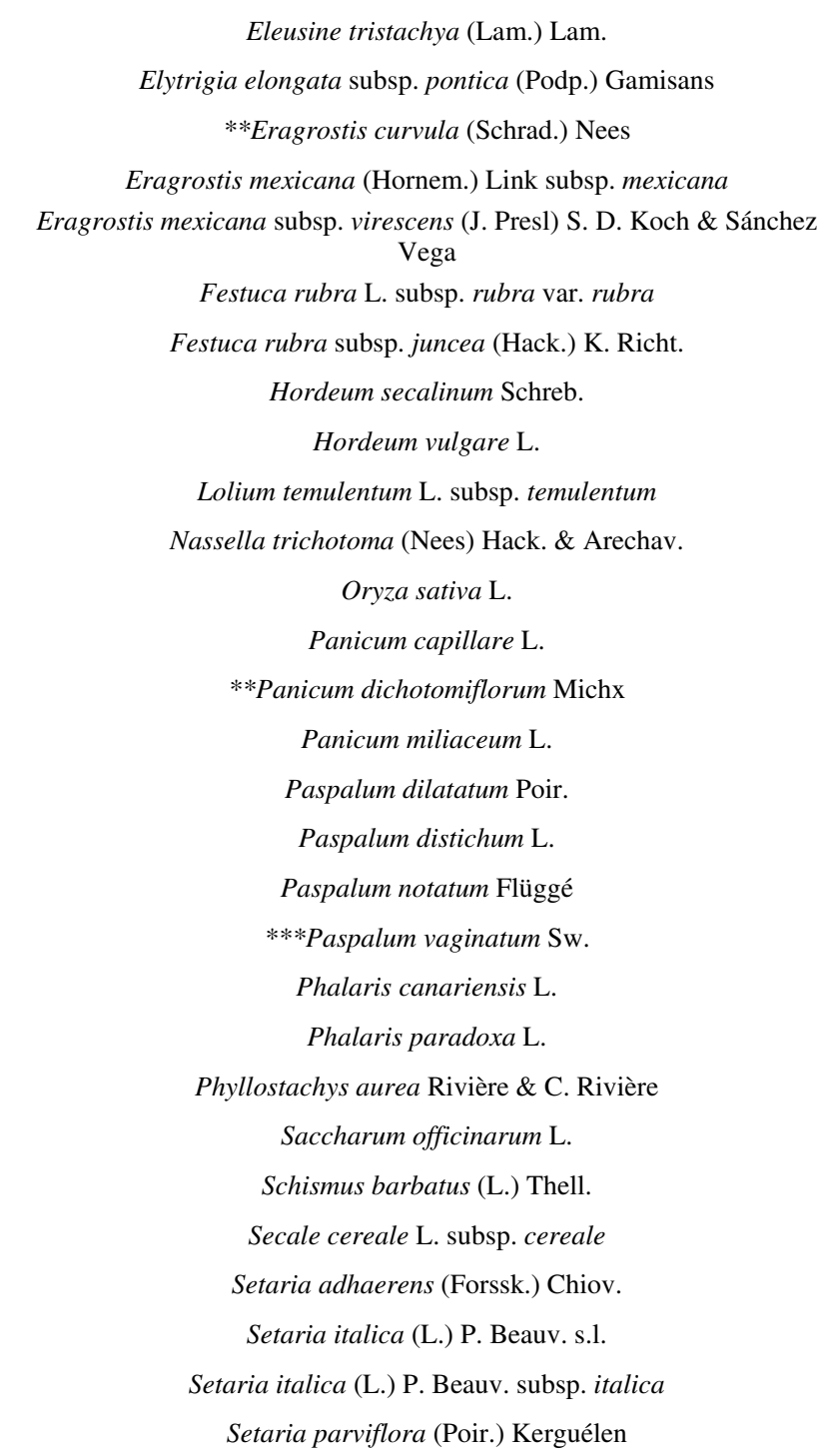

\begin{tabular}{|c|c|c|c|c|c|c|}
\hline & 1 & & $\mathrm{Neo}$ & & Cas & Riparian \\
\hline & 1 & & $\mathrm{Neo}$ & & Cas & Synanthropic \\
\hline \multirow[t]{6}{*}{1} & & $\mathrm{Neo}$ & & Cas & & Synanthropic \\
\hline & 1 & & $\mathrm{Neo}$ & & Cas & Synanthropic \\
\hline & 1 & & $\mathrm{Neo}$ & & Cas & Synanthropic \\
\hline & 1 & & Arch & & Cas & Synanthropic \\
\hline & D & & Arch & & Cas & Agricultural \\
\hline & $\mathrm{D}$ & & $\mathrm{Da}$ & & Cas & Matorrals \\
\hline \multirow[t]{3}{*}{1} & 1 & Arch & Arch & Nat & Cas & Agricultural \\
\hline & 1 & & Arch & & Cas & Agricultural \\
\hline & 1 & & $\mathrm{Neo}$ & & Inv & Synanthropic \\
\hline \multirow[t]{2}{*}{1} & & Arch & & Cas & & Wetlands \\
\hline & 1 & & $\mathrm{Neo}$ & & Inv & Wetlands \\
\hline 1 & 1 & $\mathrm{Neo}$ & $\mathrm{NeO}$ & Nat & Cas & Wetlands \\
\hline 1 & 1 & Arch & Arch & Cas & Cas & Wetlands \\
\hline 1 & 1 & $\mathrm{Neo}$ & $\mathrm{Neo}$ & Nat & Inv & Wetlands \\
\hline \multirow[t]{2}{*}{1} & 1 & Neo & $\mathrm{Neo}$ & Inv & Inv & Wetlands \\
\hline & 1 & & $\mathrm{Neo}$ & & Cas & Agricultural \\
\hline 1 & 1 & $\mathrm{Neo}$ & $\mathrm{Neo}$ & Nat & Cas & Coastal \\
\hline \multirow[t]{3}{*}{1} & 1 & $\mathrm{Neo}$ & $\mathrm{Neo}$ & Inv & Nat & Agricultural \\
\hline & 1 & & $\mathrm{Da}$ & & Nat & Agricultural \\
\hline & 1 & & $\mathrm{Neo}$ & & Inv & Riparian \\
\hline \multirow[t]{2}{*}{1} & & Arch & & Cas & & Agricultural \\
\hline & D & & $\mathrm{Da}$ & & Cas & Synanthropic \\
\hline \multirow[t]{2}{*}{1} & 1 & Arch & Arch & Cas & Cas & Agricultural \\
\hline & 1 & $\mathrm{Neo}$ & $\mathrm{Neo}$ & Nat & Nat & Synanthropic \\
\hline 1 & 1 & Arch & $\mathrm{Neo}$ & Nat & Nat & Agricultural \\
\hline 1 & & Arch & & Nat & & Agricultural \\
\hline 1 & 1 & $\mathrm{Neo}$ & $\mathrm{Neo}$ & Cas & Inv & Synanthropic \\
\hline
\end{tabular}




$\begin{array}{lc}716 & \text { Poaceae } \\ 717 & \text { Poaceae } \\ 718 & \text { Poaceae } \\ 719 & \text { Poaceae } \\ 720 & \text { Poaceae } \\ 721 & \text { Poaceae } \\ 722 & \text { Poaceae } \\ 723 & \text { Poaceae } \\ 724 & \text { Poaceae } \\ 725 & \text { Poaceae } \\ 726 & \text { Poaceae } \\ 727 & \text { Poaceae } \\ 728 & \text { Poaceae } \\ 729 & \text { Poaceae } \\ 730 & \text { Poaceae } \\ 731 & \text { Poaceae } \\ 732 & \text { Polygalaceae } \\ 733 & \text { Polygonaceae } \\ 734 & \text { Polygonaceae } \\ 735 & \text { Polygonaceae } \\ 736 & \text { Polygonaceae } \\ 737 & \text { Polygonaceae } \\ 738 & \text { Polygonaceae } \\ 739 & \text { Polygonaceae } \\ 740 & \text { Polygonaceae } \\ 741 & \text { Pontederiaceae } \\ 742 & \text { Pontederiaceae } \\ 743 & \text { Pontederiaceae } \\ 744 & \text { Portulacaceae } \\ & \\ 725\end{array}$

Setaria pumila (Poir.) Roem. \& Schult.

****Setaria verticillata $(\mathrm{L}$.) P. Beauv.

****Setaria verticillata var. ambigua (Guss.) Parl.

Setaria viridis (L.) P. Beauv. subsp. viridis

*Setaria viridis subsp. pycnocoma (Steud.) Tzvelev

Sorghum bicolor (L.) Moench

Sorghum halepense (L.) Pers.

Spartina versicolor $\mathrm{E}$. Fabre

Sporobolus indicus (L.) R.Br.

Stenotaphrum secundatum (Walter) Kuntze

Stipa neesiana Trin. \& Rupr

Trisetum flavescens (L.) P. Beauv. subsp. flavescens

Triticum aestivum $\mathrm{L}$.

**Triticum durum Desf

Triticum turgidum $\mathrm{L}$.

$$
\text { Zea mays } \mathrm{L} \text {. }
$$

Polygala myrtifolia $\mathrm{L}$

Emex spinosa (L.) Campd.

Fallopia baldschuanica (Regel) Holub

Fallopia dumetorum (L.) Holub

Persicaria capitata (D. Don) H. Gross

Reynoutria japonica Houtt.

****Reynoutria $\times$ bohemica Chrtek \& Chrtkova

Rumex acetosa L. subsp. acetosa

$$
\text { Rumex lunaria } \mathrm{L} \text {. }
$$

Eichhornia crassipes (Mart.) Solms

Heteranthera limosa Willd.

Heteranthera rotundifolia (Kunth) Griseb.

Portulaca grandiflora Hook.
Arch

Da

Arch

$\mathrm{Da}$

Arch

Arch

Arch

$\mathrm{NeO}$

$\mathrm{Neo}$

$\mathrm{NeO}$

Neo
Nat

Nat

Nat

Nat

Cas

Cas

Inv

Nat

Cas

Nat

Nat

Nat

Cas

Nat

Inv

Cas

Cas

Nat

Cas

Synanthropic

Agricultural

Agricultural

Synanthropic

Coastal

Riparian

Synanthropic

Synanthropic

Synanthropic

Agricultural

Agricultural

Agricultural

Wetlands

Synanthropic

Synanthropic

Synanthropic

Agricultural

Cas Synanthropic

Inv Wetlands

Inv Wetlands

Nat

Agricultural

Nat

Synanthropic

Cas

Wetlands

Wetlands

Wetlands

Synanthropic 


$\begin{array}{ll}745 & \text { Portulacaceae } \\ 746 & \text { Portulacaceae } \\ 747 & \text { Portulacaceae } \\ 748 & \text { Primulaceae } \\ 749 & \text { Primulaceae } \\ 750 & \text { Ranunculaceae } \\ 751 & \text { Ranunculaceae } \\ 752 & \text { Ranunculaceae } \\ 753 & \text { Ranunculaceae } \\ 754 & \text { Ranunculaceae } \\ 755 & \text { Ranunculaceae } \\ 756 & \text { Ranunculaceae } \\ 757 & \text { Ranunculaceae } \\ 758 & \text { Ranunculaceae } \\ 759 & \text { Ranunculaceae } \\ 760 & \text { Ranunculaceae } \\ 761 & \text { Rhamnaceae } \\ 762 & \text { Rhamnaceae } \\ 763 & \text { Rhamnaceae } \\ 764 & \text { Rhamnaceae } \\ 765 & \text { Rosaceae } \\ 766 & \text { Rosaceae } \\ 767 & \text { Rosaceae } \\ 768 & \text { Rosaceae } \\ 769 & \text { Rosaceae } \\ 770 & \text { Rosaceae } \\ 771 & \text { Rosaceae } \\ 772 & \text { Rosaceae } \\ 773 & \text { Rosaceae } \\ & \\ 750\end{array}$

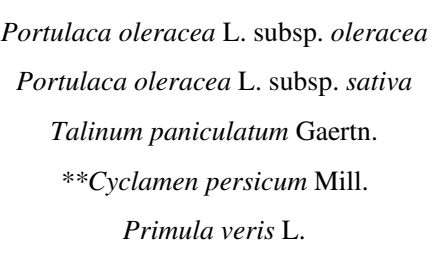

Adonis aestivalis L. subsp. aestivalis

Adonis aestivalis L. subsp. squarrosa (Steven) Nyman

****Adonis annua L. subsp. cupaniana (Guss.) C. Steinb.

Anemone coronaria $\mathrm{L}$.

Anemone nemorosa $\mathrm{L}$.

Delphinium ajacis $\mathrm{L}$.

Delphinium consolida $\mathrm{L}$.

$$
\text { Nigella sativa } \mathrm{L} \text {. }
$$

Ranunculus acris L. subsp. acris

Ranunculus arvensis $\mathrm{L}$.

Ranunculus serpens Schrank subsp. nemorosus (DC.) G. López

$$
\text { Paliurus spina-christi Mill. }
$$

Rhamnus cathartica $\mathrm{L}$.

Ziziphus lotus (L.) Lam.

Ziziphus zizyphus (L.) H. Karst.

Cotoneaster horizontalis Decne

Crataegus azarolus $\mathrm{L}$.

Crataegus crus-galli $\mathrm{L}$

Crataegus germanica (L.) Kuntze

Cydonia oblonga Mill.

Eriobotrya japonica (Thunb.) Lindl.

Fragaria $\times$ ananassa $($ Weston) Decne. \& Naudin

Malus dasyphylla Borkh.

Malus pumila Mill.
Da

$\mathrm{NeO}$

$\mathrm{NeO}$

1

$\mathrm{Da}$

Arch

Arch

Neo

$\mathrm{Da}$

Arch

Arch

Arch

Da

$\mathrm{Da}$

$\mathrm{Da}$

Arch

Da

Arch

Neo

Arch

Arch

Arch

Arch

Arch

Arch

Neo

Da

Arch

Da

Neo

Arch

Arch

Arch

$\mathrm{NeO}$

Arch
Arch
Neo
Arch
Arch
Neo
Da

Arch

Inv

Nat

Agricultural

Synanthropic

Cas

Cas

Synanthropic

Synanthropic

Cas

Woodlands

Cas

Agricultural

Agricultural

Cas

Agricultural

Cas Synanthropic

Nat Woodlands

Nat

Nat

Cas

Cas

Cas

\section{Synanthropic}

Synanthropic

Agricultural

Cas

Synanthropic

Agricultural

Wetlands

Synanthropic

Woodlands

Nat

Cas

Cas
Agricultural

Synanthropic

Synanthropic

Synanthropic

Agricultural

Agricultural

Agricultural

Agricultural

Woodlands

Agricultural 


\begin{tabular}{ll}
774 & Rosaceae \\
775 & Rosaceae \\
776 & Rosaceae \\
777 & Rosaceae \\
778 & Rosaceae \\
779 & Rosaceae \\
780 & Rosaceae \\
781 & Rosaceae \\
782 & Rosaceae \\
783 & Rosaceae \\
784 & Rosaceae \\
785 & Rosaceae \\
786 & Rosaceae \\
787 & Rosaceae \\
788 & Rosaceae \\
789 & Rosaceae \\
790 & Rubiaceae \\
791 & Rubiaceae \\
792 & Ruscaceae \\
793 & Rutaceae \\
794 & Rutaceae \\
795 & Salicaceae \\
796 & Salicaceae \\
797 & Salicaceae \\
798 & Salicaceae \\
799 & Salicaceae \\
800 & Salviniaceae \\
801 & Salviniaceae \\
802 & Sapindaceae \\
\hline 7
\end{tabular}

Potentilla indica (Andrews) Th. Wolf

Prunus armeniaca $\mathrm{L}$.

Prunus avium L. subsp. avium

Prunus cerasus $\mathrm{L}$.

Prunus cocomilia Ten

Prunus domestica L. subsp. domestica

Prunus domestica L. subsp. insititia (L.) Bonnier et Layens

Prunus dulcis (Mill.) D.A. Webb

Prunus laurocerasus $\mathrm{L}$

*Prunus mahaleb $\mathrm{L}$.

Prunus persica (L.) Batsch

Pyracantha coccinea M. Roem.

Pyrus communis $\mathrm{L}$

Rosa gallica $\mathrm{L}$.

Rubus idaeus L. subsp. idaeus

Sorbus domestica $\mathrm{L}$.

Galium verum L. subsp. verum

Rubia tinctorum $\mathrm{L}$.

Ruscus hypoglossum $\mathrm{L}$

Citrus aurantium $\mathrm{L}$.

Citrus limon (L.) Burm.

Populus deltoides W. Bartram ex Marshall

Populus $\times$ canadensis Moench

Populus $\times$ canescens (Aiton) Sm.

Salix babylonica $\mathrm{L}$.

Salix fragilis $\mathrm{L}$.

Azolla filiculoides Lam.

Salvinia molesta D. S. Mitchell

Acer campestre $\mathrm{L}$.
Neo

Arch

Arch

Arch

Arch

Arch

Arch

Arch

Arch

Arch

Da

Arch

Arch

Arch

$\mathrm{Da}$

1

Arch

Arch

Arch

Arch

Neo

Neo

Neo

$\mathrm{Neo}$

$\mathrm{Neo}$

Arch
Nat

Cas

Cas

Cas

Cas

Arch

Arch

Arch

Neo

Arch

Neo

Arch

Cas

Cas

Cas

Nat

Cas

Cas

Cas

Cas

Cas

o

Cas

Nat

Cas

Cas

Nat

Cas

$\mathrm{Neo}$

$\mathrm{Neo}$

Neo

$\mathrm{Neo}$

$\mathrm{Da}$
Wetlands

Agricultural

Agricultural

Agricultural

Agricultural

Agricultural

Agricultural

Agricultural

Agricultural

Woodlands

Agricultural

Synanthropic

Matorrals

Synanthropic

Wetlands

Woodlands

Cas

Synanthropic

Synanthropic

Synanthropic

Agricultural

Agricultural

Riparian

Riparian

Riparian

Riparian

Riparian

Inv Wetlands

Inv Riparian

Nat Synanthropic 


\begin{tabular}{lc}
803 & Sapindaceae \\
804 & Sapindaceae \\
805 & Sapindaceae \\
806 & Sapindaceae \\
807 & Sapindaceae \\
808 & Scrophulariaceae \\
809 & Scrophulariaceae \\
810 & Scrophulariaceae \\
811 & Scrophulariaceae \\
812 & Scrophulariaceae \\
813 & Scrophulariaceae \\
814 & Selaginellaceae \\
815 & Simaroubaceae \\
816 & Solanaceae \\
817 & Solanaceae \\
818 & Solanaceae \\
819 & Solanaceae \\
820 & Solanaceae \\
821 & Solanaceae \\
822 & Solanaceae \\
823 & Solanaceae \\
824 & Solanaceae \\
825 & Solanaceae \\
826 & Solanaceae \\
827 & Solanaceae \\
828 & Solanaceae \\
829 & Solanaceae \\
830 & Solanaceae \\
831 & Solanaceae \\
\hline
\end{tabular}

\author{
Acer negundo $\mathrm{L}$. \\ Acer platanoides $\mathrm{L}$. \\ Acer pseudoplatanus $\mathrm{L}$. \\ Aesculus hippocastanum $\mathrm{L}$. \\ Cardiospermum halicacabum $\mathrm{L}$. \\ Buddleja davidii Franch. \\ Myoporum insulare R. Br. \\ Myoporum laetum G. Forst \\ Myoporum tenuifolium G. Forst. \\ Myoporum tetrandrum (Labill.) Domin \\ Russelia equisetiformis Schlecht. et Cham. \\ Selaginella kraussiana (Kunze) A. Braun \\ Ailanthus altissima (Mill.) Swingle \\ Capsicum annuит L. \\ Datura ferox $\mathrm{L}$. \\ Datura innoxia Mill. \\ Datura stramonium L. subsp. stramonium \\ Datura wrightii Regel \\ Jaborosa integrifolia Lam. \\ *****Lycium barbarum $\mathrm{L}$. \\ Lycium europaeum $\mathrm{L}$. \\ **Lycium ferocissimum Miers \\ Lycium intricatum Boiss. \\ Lycopersicon esculentum Mill. \\ Nicotiana glauca Graham \\ Nicotiana rustica $\mathrm{L}$. \\ Nicotiana tabacum L. \\ Petunia $\times$ punctata Paxton \\ Physalis peruviana $\mathrm{L}$.
}

\begin{tabular}{|c|c|}
\hline \multirow[t]{2}{*}{1} & 1 \\
\hline & 1 \\
\hline 1 & \\
\hline 1 & \\
\hline \multirow[t]{2}{*}{1} & \\
\hline & 1 \\
\hline 1 & 1 \\
\hline 1 & 1 \\
\hline \multicolumn{2}{|c|}{$\mathrm{D}$} \\
\hline \multicolumn{2}{|c|}{1} \\
\hline \multicolumn{2}{|c|}{1} \\
\hline & 1 \\
\hline 1 & 1 \\
\hline \multicolumn{2}{|c|}{1} \\
\hline \multicolumn{2}{|c|}{1} \\
\hline \multicolumn{2}{|c|}{1} \\
\hline 1 & 1 \\
\hline 1 & 1 \\
\hline \multicolumn{2}{|c|}{1} \\
\hline & 1 \\
\hline 1 & 1 \\
\hline \multicolumn{2}{|c|}{1} \\
\hline \multicolumn{2}{|c|}{$\mathrm{D}$} \\
\hline & 1 \\
\hline \multirow[t]{2}{*}{1} & 1 \\
\hline & D \\
\hline \multirow[t]{3}{*}{1} & 1 \\
\hline & 1 \\
\hline & 1 \\
\hline
\end{tabular}

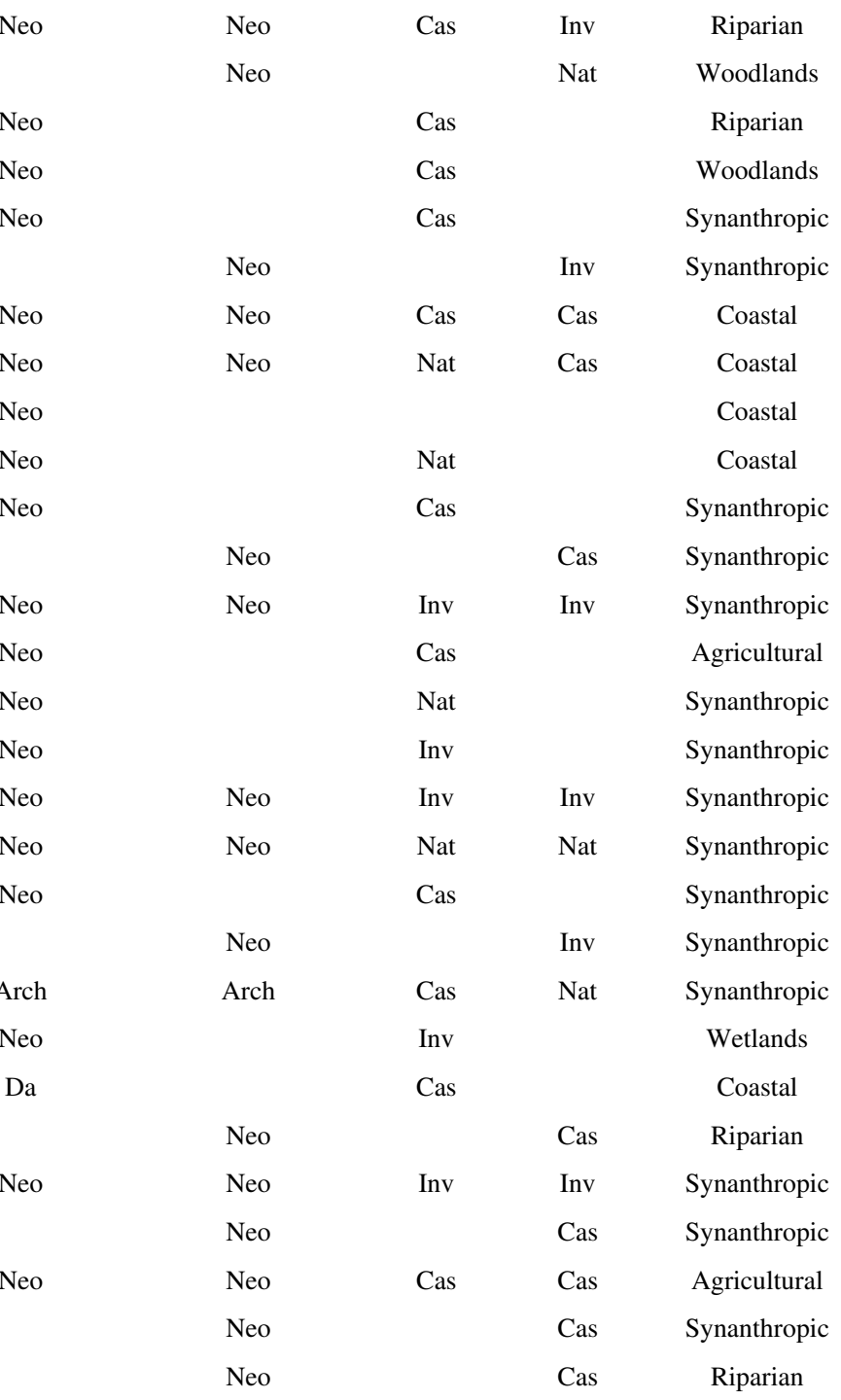




$\begin{array}{lc}832 & \text { Solanaceae } \\ 833 & \text { Solanaceae } \\ 834 & \text { Solanaceae } \\ 835 & \text { Solanaceae } \\ 836 & \text { Solanaceae } \\ 837 & \text { Solanaceae } \\ 838 & \text { Solanaceae } \\ 839 & \text { Solanaceae } \\ 840 & \text { Solanaceae } \\ 841 & \text { Solanaceae } \\ 842 & \text { Solanaceae } \\ 843 & \text { Solanaceae } \\ 844 & \text { Solanaceae } \\ 845 & \text { Solanaceae } \\ 846 & \text { Tamaricaceae } \\ 847 & \text { Tamaricaceae } \\ 848 & \text { Tamaricaceae } \\ 849 & \text { Tamaricaceae } \\ 850 & \text { Tamaricaceae } \\ 851 & \text { Tamaricaceae } \\ 852 & \text { Taxodiaceae } \\ 853 & \text { Taxodiaceae } \\ 854 & \text { Tropaeolaceae } \\ 855 & \text { Ulmaceae } \\ 856 & \text { Ulmaceae } \\ 857 & \text { Urticaceae } \\ 858 & \text { Verbenaceae } \\ 859 & \text { Verbenaceae } \\ 860 & \text { Verbenaceae } \\ & \end{array}$

**Salpichroa origanifolia (Lam.) Baill.

$$
\text { Solanum bonariense } \mathrm{L} \text {. }
$$

Solanum chenopodioides Lam.

Solanum elaeagnifolium Cav.

Solanum laciniatum Aiton

*Solanum linnaeanum Hepper \& P.-M.L. Jaeger

Solanum lycopersicum $\mathrm{L}$.

***Solanum mauritianum Scop.

Solanum melongena $\mathrm{L}$

Solanum pseudocapsicum $\mathrm{L}$.

Solanum rostratum Dunal

Solanum sisymbrifolium Lam.

Solanum tuberosum L.

Withania somnifera (L.) Dunal subsp. somnifera Tamarix gallica $\mathrm{L}$.

Tamarix hampeana Boiss. \& Heldr. emend. Boiss.

$$
\text { Tamarix parviflora DC. }
$$

Tamarix passerinoides Delile

Tamarix tetragyna Ehrenb.

Tamarix tetrandra Pall. ex M. Bieb.

Sequoiadendron giganteum (Lindl.) Buchholz

Taxodium distichum (L.) Richt.

Tropaeolum majus $\mathrm{L}$.

Ulmus laevis Pall.

Ulmus minor Mill. subsp. minor

Parietaria cretica L.

Aloysia citriodora Palau

Lantana camara $\mathrm{L}$.

Phyla canescens (Kunth) Greene

\begin{tabular}{|c|c|c|c|c|}
\hline \multirow[t]{3}{*}{ Neo } & Neo & Cas & Inv & Synanthropic \\
\hline & $\mathrm{Neo}$ & & Cas & Synanthropic \\
\hline & $\mathrm{Neo}$ & & Inv & Synanthropic \\
\hline \multirow[t]{2}{*}{$\mathrm{Neo}$} & & Inv & & Synanthropic \\
\hline & $\mathrm{Neo}$ & & Cas & Synanthropic \\
\hline $\mathrm{Neo}$ & $\mathrm{Neo}$ & Inv & Nat & Synanthropic \\
\hline \multirow[t]{2}{*}{$\mathrm{Neo}$} & Neo & Cas & Cas & Agricultural \\
\hline & Neo & & Nat & Synanthropic \\
\hline \multirow[t]{2}{*}{ Arch } & & Cas & & Agricultural \\
\hline & Neo & & Cas & Synanthropic \\
\hline $\mathrm{Neo}$ & & Nat & & Synanthropic \\
\hline $\mathrm{Neo}$ & & Inv & & Synanthropic \\
\hline $\mathrm{Neo}$ & $\mathrm{Neo}$ & Cas & Cas & Agricultural \\
\hline \multirow[t]{2}{*}{$\mathrm{Neo}$} & & Nat & & Synanthropic \\
\hline & $\mathrm{Da}$ & & Nat & Riparian \\
\hline $\mathrm{Da}$ & & & & Wetlands \\
\hline $\mathrm{Neo}$ & $\mathrm{Neo}$ & Cas & Inv & Coastal \\
\hline $\mathrm{Da}$ & & & & Wetlands \\
\hline $\mathrm{Da}$ & & & & Wetlands \\
\hline $\mathrm{Da}$ & & & & Wetlands \\
\hline Neo & & Cas & & Woodlands \\
\hline $\mathrm{Neo}$ & & Cas & & Wetlands \\
\hline \multirow[t]{2}{*}{$\mathrm{Neo}$} & $\mathrm{Neo}$ & Nat & Inv & Riparian \\
\hline & $\mathrm{Da}$ & & Cas & Woodlands \\
\hline $\mathrm{Da}$ & & & & Agricultural \\
\hline $\mathrm{Da}$ & & Nat & & Synanthropic \\
\hline Neo & & Cas & & Synanthropic \\
\hline Neo & Neo & Cas & Cas & Coastal \\
\hline $\mathrm{Neo}$ & $\mathrm{Neo}$ & Cas & Cas & Synanthropic \\
\hline
\end{tabular}

1
1
1
1
1
1
1
1
1
D
D
D
D
D
1
1
1
1
1
1
1
1
1
1
1
1
1
1
1
1
1
1
1
1
1




$\begin{array}{lc}861 & \text { Verbenaceae } \\ 862 & \text { Violaceae } \\ 863 & \text { Violaceae } \\ 864 & \text { Vitaceae } \\ 865 & \text { Vitaceae } \\ 866 & \text { Vitaceae } \\ 867 & \text { Vitaceae } \\ 868 & \text { Vitaceae } \\ 869 & \text { Vitaceae } \\ 870 & \text { Vitaceae } \\ 871 & \text { Vitaceae } \\ 872 & \text { Vitaceae } \\ 873 & \text { Vitaceae } \\ 874 & \text { Xanthorrhoeaceae } \\ 875 & \text { Xanthorrhoeaceae } \\ 876 & \text { Xanthorrhoeaceae } \\ 877 & \text { Xanthorrhoeaceae } \\ 878 & \text { Xanthorrhoeaceae } \\ 879 & \text { Xanthorrhoeaceae } \\ 880 & \text { Zygophyllaceae } \\ 881 & \text { Zygophyllaceae }\end{array}$

Phyla nodiflora (L.) Greene

*Viola odorata $\mathrm{L}$

Viola tricolor $\mathrm{L}$.

Parthenocissus inserta (A. Kern.) Fritsch

Parthenocissus quinquefolia (L.) Planch.

Vitis labrusca $\mathrm{L}$.

Vitis riparia Michx.

**Vitis rupestris Scheele

Vitis vinifera L. subsp. vinifera

Vitis vinifera L. subsp. sylvestris (C.C. Gmel.) Hegi

****itis $\times$ instabilis Ardenghi, Galasso, Banfi \& Lastrucci

**Vitis $\times$ koberi Ardenghi, Galasso, Banfi \& Lastrucci

**Vitis $\times$ ruggerii Ardenghi, Galasso, Banfi \& Lastrucci

Aloe $\times$ caesia Salm-Dyck

Aloe arborescens Mill.

Aloe maculata All.

**Aloe perfoliata $\mathrm{L}$.

Aloe vera (L.) Burm. fil.

Phormium tenax Forst

Tribulus terrestris $\mathrm{L}$.

Zygophyllum fabago $\mathrm{L}$.

Neo
Arch
Arch
Neo
Neo
Neo
Neo
Arch
Da

Neo
Neo
Neo
Neo
Neo
Neo
Arch
Neo
Da
Arch

Da

Nat

$\mathrm{Nat}$

Wetlands

Neo

Cas

$\mathrm{Neo}$

$\mathrm{NeO}$

Neo

Arch

Neo

Cas

Inv

Synanthropic

Synanthropic

Synanthropic

Synanthropic

Cas

Nat

Agricultural

Riparian

Nat

Agricultural

Riparian

Riparian

Nat

Matorrals

Agricultural

Agricultural

Synanthropic

$\mathrm{NeO}$

Inv

Coastal

Coastal

Synanthropic

Coastal

Synanthropic

Synanthropic

Agricultural 